\title{
LA REVISITA DE CODPA (ALTOS DE ARICA) DE 1772-73 EFECTUADA POR EL CORREGIDOR DEMETRIO EGAN ${ }^{1}$
}

\author{
THE REVISITA TO CODPA (HIGHLAND OF ARICA) 1772-73, \\ REALIZED BY CORREGIDOR DEMETRIO EGAN
}

\author{
Jorge Hidalgo*, Nelson Castro** y Soledad Gonzalez***
}

Dedicado a la memoria de Franklin Pease†

\begin{abstract}
En este estudio hemos demostrado cómo la unidad social "Cacicazgo de Codpa" fue una construcción colonial del siglo XVII como resultado de la acción histórica complementaria de fuerzas sociales relacionadas, pero independientes en sus intereses que, sin embargo, coincidieron en un proceso que fue conveniente para campesinos andinos de diversos orígenes.

El documento que publicamos, junto con el estudio, forman parte de una cadena de textos similares o comparables. Sin intentar un listado completo, está en la línea de la "Revisita de los Altos de Arica" realizada por el oficial real Joaquín de Cárdenas en 1750 y que publicamos en forma completa en una modesta edición de 100 ejemplares a mimeógrafo en 1978. Ambas revisitas se suceden en el tiempo luego de 22 años y se aplican al mismo conjunto social y geográfico. Esta revisita es comparable con las revisitas realizadas contemporáneamente a otros cacicazgos por el mismo Egan, en el Corregimiento de Arica, lo que permite analizar las conductas y políticas de este corregidor así como tener una visión del conjunto del Corregimiento.

El valor de los documentos históricos radica en la información que contienen con relación a una determinada sociedad en el tiempo. En este sentido, el documento que publicamos contiene gran cantidad de información demográfica y de la organización política para el o los años de la encuesta (segunda mitad del siglo XVIII).
\end{abstract}

Palabras claves: historia colonial indígena local, siglos XVII y XVIII, Arica, Codpa.

In this study we demonstrate that the social unit named the "Chiefdom of Codpa" was a colonial construction of the $17^{\text {th }}$ century, as a consequence of interrelated but independent social forces that merge in a social process that was convenient for the Andean farmers of different origin that integrated this community.

Along with this study we publish a colonial document, which is part of a series of other document of similar nature, as the "Revisita en los Altos de Arica" carried out by the royal officer Joaquín de Cárdenas in 1750, published in a modest edition of 100 copies, in 1978. Both revisitas are separated in time by 22 years, and took place in the same geographic and social setting. The revisita of Egan to Codpa is comparable with contemporaneous inspections to other chiefdoms in the Corregimiento of Arica realized by this Corregidor, and allow us to analyze the politics and behavior of this personage, as well as to shed light on the social condition of the Corregimiento in general.

The value of historic documents emanates from the information they contain regarded to a particular society in time. The document we publish here contains a great amount of demographic information as well as issues linked to political organization in the colonial time covered by the document (second half of $18^{\text {th }}$ century).

Key words: Indian local colonial history, $17^{\text {th }}$ and XVIIIth centuries, Codpa, Arica.

Ortega señalaba que los hombres no tienen naturaleza, sólo historia. Aun cuando las investigaciones actuales no concuerdan con las reflexiones del filósofo español, estableciendo una mayor relación entre la biología y la conducta, se puede aceptar que el hombre está constantemente autoconstruyéndose y transformándose en las relaciones lingüísticas y sociohistóricas ${ }^{2}$. Sin duda estos cambios afectan o son producidos incluso por sociedades campesinas alejadas de los sitios de poder, como los pueblos andinos de las desérticas sierra, altiplano y oasis de Arica, Tarapacá y Atacama ${ }^{3}$. La apariencia de inmovilidad se desvanece en una mirada más cercana, donde descubrimos sus constantes transformaciones internas y cómo su integración en el sistema de gobierno colonial supuso

\footnotetext{
* Universidad de Chile y Centro de Investigaciones del Hombre en el Desierto, Universidad de Tarapacá, Arica, Chile. hidalgol@uchile.cl

** Universidad de Valparaíso y Universidad Técnica Federico Santa María.

*** Universidad de Valparaíso. Magíster en Historia de la Universidad de Chile.

$\dagger$ Este estudio fue desde sus comienzos inspirado en la memoria de Franklin Pease, lo que no le resta méritos al homenaje a Luis Álvarez en este número de la revista.
} 
una larga historia de relaciones con el Estado, la iglesia, el mercado y otras agencias que terminaron siendo parte de sus propios esquemas de vida. Por cierto que estos procesos de integración no los constituyeron ni en españoles, ni en mestizos; tampoco su condición de "indios", categoría colonial, fue similar a la de sus antepasados prehispánicos, o idéntica a la de sus vecinos contemporáneos, aun cuando la mayor parte de ellos continuara hablando aymará o cunza y cultivando la tierra con una tecnología en gran parte heredada de los abuelos.

En otros trabajos hemos demostrado que la unidad social "Cacicazgo de Codpa" fue una construcción colonial del siglo XVII como resultado de la acción histórica complementaria de fuerzas sociales relacionadas, pero independientes en sus intereses que, sin embargo, coincidieron en un proceso que fue conveniente para campesinos andinos de diversas procedencias, aunque mayoritariamente vinculados por sus orígenes con Carangas, que de ese modo se desvinculaban de la mita de Potosí y de otras obligaciones; fue también una oportunidad para que diversos líderes locales consolidaran y ampliaran la esfera de poder étnico, entre los que triunfó una familia que creó un linaje de descendencia patrilineal que se ajustaba a las concepciones europeas de primogenitura, pero que a la vez supo utilizar los mecanismos de reciprocidad andina; y, por último, también fue un instrumento exitoso para los corregidores españoles de Arica que pudieron resolver sus esporádicos conflictos con los corregidores de Carangas, pudiendo controlar los tributos y la mano de obra de una zona que, por su extensión y características orográficas y climáticas, era muy difícil de administrar sin la colaboración de los campesinos y sus líderes andinos ${ }^{4}$.

De ahí que los cambios ocurridos en esta área desde tiempos prehispánicos no permiten anticipar necesariamente una solución de continuidad entre los asentamientos del siglo XVIII y aquellos del siglo XVI aun cuando los nombres de los valles puedan en algunos casos ser los mismos. Aun resta mucho por investigar en este terreno. Hay que recordar los significativos cambios que introduce la acción de instaurar pueblos en la época de Toledo que significó la eliminación de numerosos asentamientos dispersos para fundar pueblos donde la población concentrada fuera más fácil de adoctrinar y de ser convocada para las tareas y exigencias coloniales. Juan Maldonado Buendía, el capitán español enviado por Toledo a realizar esta tarea en la provincia de Collesuyo o Moquegua, que se extendía desde el río de Arequipa hasta el Loa, encontró 226 pueblos que redujo a 22, estableciendo trece doctrinas para administrar los sacramentos ${ }^{5}$. Con posterioridad al proceso toledano, los pueblos andinos, organizados en el esquema hispano, continuaron desplazándose o cambiando sus asentamientos por diversas causas, entre ellas conflictos internos ${ }^{6}$.

$\mathrm{Al}$ aproximarnos a un documento como el que ahora publicamos debemos tener presente que puede ser objeto de múltiples lecturas ${ }^{7}$. Forma parte de una cadena de textos similares o comparables. Sin intentar un listado completo, está en la línea de la "Revisita de los Altos de Arica" realizada por el oficial real Joaquín de Cárdenas en 1750 y que publicamos completa en una modesta edición de 100 ejemplares a mimeógrafo en 1978; ambas revisitas se superponen en el tiempo luego de 22 años y en el mismo conjunto social y geográfico. Por otra parte, es comparable con las revisitas contemporáneas de otros cacicazgos realizadas por el mismo Egan en el Corregimiento de Arica que permiten analizar las conductas y políticas de este corregidor, así como tener una visión del conjunto del Corregimiento. En ambos casos, se trata de censos de la población indígena que se ajustan a un modelo de encuesta estatal que busca información de "indios" esa única categoría de personas que pagaban tributos personales en la sociedad colonial hispana. Desde un punto de vista demográfico es de interés comparar este tipo de listado con los libros eclesiásticos parroquiales de registros de bautismos, matrimonios y fallecimientos. En este último sentido la revisita tiene ventajas y desventajas. Por una parte, se trata de una visión más cercana a la idea de censo, una fotografía instantánea del estado total de la población en un momento determinado del tiempo; por otra, se limita sólo a la población reconocida como indígena y, por tanto, deja fuera a todos aquellos que escapaban a esta condición o que pertenecían a otras castas o que fueran considerados mestizos o blancos y que sí aparecen en los libros parroquiales.

El valor de los documentos históricos radica en la información que contienen con relación a una determinada sociedad en el tiempo. En este sentido, el tipo de documento del que forma parte el que ahora publicamos es uno que contiene gran cantidad de información demográfica y de la organización política para el o los años de la encuesta. El documento "revisita" es lejanamente compara- 
ble a un trabajo de campo en la medida que es un recorrido por los diferentes pueblos del cacicazgo recolectando información que se traduce en un listado de toda la población considerada indígena, organizada por unidades censales o geográficas que es, a su vez, subdividida en otros listados. Las unidades principales son los pueblos que en algunos casos coinciden con ayllus y en otros casos están subdivididas en ayllus, que es un tipo de organización que tiene más relación con lazos consanguíneos que con vínculos residenciales determinados por la geografía ${ }^{8}$. El pueblo andino, impuesto y reglamentado en los Andes, fundamentalmente, por las reformas de Toledo que se remontan a la década de 1570, quedó normado en la Recopilación de Leyes de Indias. Sin embargo, las transformaciones históricas obligaron a la burocracia a reconocer nuevos tipos de pobladores que se incluyeron en las instrucciones entregadas a los visitadores ${ }^{9}$. Dos criterios normaban los listados que tenían como finalidad establecer el pago del tributo diferenciado por el origen de los varones tributarios así como la jerarquía política para su recolección. Por una parte, el conjunto formado por el sexo, estado civil, edad y, por otra, el origen o ascendencia. A ello se agrega la jerarquía política que no siempre es visible; normalmente la autoridad superior o cacique encabeza los listados; otros cargos como los integrantes del cabildo indígena o ayudantes de la Iglesia no se mencionan en el cuerpo de esta revisita; sin embargo, en la foja $78 \mathrm{v}$, se listan 23 indios exentos de tributo o rebajados por sus cargos y son: una segunda persona del cacique, seis sacristanes, seis cobradores y 10 alcaldes de los pueblos. En cada unidad censal se inicia la revisita con los "originarios casados" y sus esposas e hijos, en algunos casos estos subconjuntos corresponden a familias nucleares y en otros a fragmentos de esas estructuras en la medida que cada hijo mayor de 18 años o casado pasa a formar parte de otro listado; lo mismo ocurre con algunas mujeres dependiendo de sus edades y estado. Siguen los "originarios viudos" y luego los "originarios solteros". Se finaliza con los "originarios reservados", éstos eran los mayores de 50 años o incapacitados por enfermedades, ambas condiciones los excluían legalmente de la condición de tributario. Luego seguían las diversas categorías de "originarias" mujeres, solteras y viudas. Se repetían estos datos en las categorías de forasteros, cholos y zambaigos. De cada persona se informan, además del nombre, sus edades.
Los tributarios se incluían en varias categorías de acuerdo a su origen. Los originarios eran aquellos tributarios que se suponían descendientes de los primeros pobladores. Normalmente los originarios gozaban de tierras hereditarias; sin embargo, hay excepciones, como verán los lectores. En los originarios recaían, además, las responsabilidades y los cargos políticos de la comunidad. En el índice onomástico hemos incluido a todos aquellos que aparecen con algún título de este tipo.

Los forasteros, en esta revisita, son migrantes radicados, casados o solteros, con o sin tierras de repartos en los pueblos del Alto de Arica que integraban el extenso cacicazgo de Codpa. En otros lugares, y en otros momentos históricos, los forasteros pueden ser una categoría de gente que, originaria de otro lugar, se encuentren radicados en el sitio de residencia por dos o más generaciones ${ }^{10}$. En esta revisita, los forasteros pagan la misma tasa que los originarios, o sea, tres pesos y un real por tercio, es decir, seis pesos dos reales anuales. Sólo los forasteros de Choquelimpie pagaban veinte reales (un peso contenía ocho reales) por tercio y el visitador Egan les igualó la tasa con la de los tributarios, argumentando que había sólo nueve de éstos en el asiento y que los forasteros disfrutaban de los relaves de las antiguas minas (foja 78r).

Los cholos y los zambaigos corresponden a categorías sociales estamentales que se fundaban en el mestizaje. Los cholos poseían un cuarto de sangre española, es decir, eran descendientes de la unión de una persona indígena con un mestizo ${ }^{11}$. Lo mismo ocurría con los zambaigos, pero en este caso se trataba de descendiente de una persona mulata con un indígena. En ambos casos podían tener o no tierras de reparto comunal. Las instrucciones, que preceden a la revisita, señalan que estaban exentos de la mita, que a esta fecha ya no existía en los Altos de Arica.

Egan menciona que en el pueblo de Codpa se había radicado en el siglo XVII una cantidad de mestizos, que recibieron en arriendo tierras de cultivo de los caciques. En el momento de la revisita los mestizos formaban más de cien familias. Egan estimó improcedente modificar esa situación para no dejar a esas familias sin recursos o en la miseria, a pesar de las demandas de los tributarios que estimaban sus tierras como escasas debido al aumento de la población. Los mestizos siguieron siendo arrendatarios con lo cual contribuían al pago de las tasas que debía recolectar el cacique. De estos mestizos de Codpa se había formado una compa- 
ñía de milicia que hacían el servicio de vigía en el puerto de Camarones y otros de la costa, en servicio del rey y sin percibir sueldo (foja 78r).

Como hemos señalado, los reservados eran los mayores de cincuenta años, edad límite para el pago de los tributos o personas que, por sus imposibilidades físicas, no estaban en condiciones de tributar. Se agregan las viudas, los huérfanos y las huérfanas, todas categorías exentas del pago de tributo. La tradición andina establecía que la propia comunidad se hiciera cargo de aquellos que no poseían la capacidad de producir sus alimentos; para ello la comunidad establecía tierras de los huérfanos, de las viudas e incluso de la Iglesia, que eran trabajadas colectivamente para proveer recursos a los beneficiarios. Hay diversas pistas que indican la vigencia de estas instituciones en la colonia tardía.

La comunidad andina colonial entonces estaba integrada por diversos tipos de personas y, sin duda, las diferencias sociales entre los propios originarios eran bastante acentuadas, aun cuando el sentido de solidaridad social era muy fuerte. La comunidad campesina andina colonial no era homogénea; sin embargo, las diferencias sociales entre campesinos andinos en estas áreas provinciales pudieron ser no tan marcadas como las que existían en otros lugares y aún menos, comparadas con la sociedad colonial en su conjunto, donde españoles y criollos eran los dueños de la mayor parte de la riqueza de valor comercial así como del poder eclesiástico y político.

Sin embargo, no debemos ver este documento tan sólo como una fotografía de la época o un texto que refleja o se limita a describir objetivamente y sin mayor intención una sociedad histórica. En realidad estamos en presencia de un acto de la autoridad colonial para hacer sentir su presencia hasta en los más lejanos y apartados pueblos del Altiplano ${ }^{12}$. El corregidor con su comitiva se hacía presente portando instrumentos de descripción que de cierta manera construyeron una realidad, hacían del campesino andino un indio, un cholo, un zambaigo, señalando y controlando el destino de los jóvenes, aprobando autoridades, investigando y haciendo observaciones en terreno sobre las autoridades, la cantidad de tierras de reparto y otras. La revisita, como cualquier otro documento histórico, debe ser analizada como un texto complejo, donde se escuchan diversas voces y hay diversas intencionalidades y actores. En este sentido es más parecido a una novela que a una carta.
Por ello debemos leer con atención los documentos que preceden a la revisita propiamente tal. Las autoridades, incluidas las más altas del Virreinato del Perú, participan dando legalmente la orden de hacer la revisita, impartiendo las instrucciones que se debían seguir; las categorías sociales que se debían encontrar; las autoridades regionales, civiles o eclesiásticas que debían participar, y quienes harían la encuesta.

Se puede imaginar la comitiva del corregidor y sus ayudantes. Ella incluía al cura, al doctor Diego de Zaconeta y a su personal que llevaban los libros parroquiales; al pregonero que anunciaba a gritos en cada esquina del pueblo la misión que los traía y las obligaciones de los tributarios de responder a la información solicitada; al escribano, que en este caso es el amanuense Rafael Bahamondes; el protector de naturales, Juan Joseff de López de Santana; el defensor de la Real Hacienda, Juan Esteban Viscarra; el Alguacil Mayor, Bernardo de Vilanova; el intérprete, Jossef Sinforiano Jimenes; el cacique principal, Diego Phelipe Cañipa; sirvientes, arrieros, los encargados de las monturas, y otros, todos los cuales debían ser alimentados y atendidos por las comunidades ${ }^{13}$. A las voces locales que registraba la visita se agregan, al final de la misma, los comentarios críticos del propio revisitador, el corregidor de Arica, Demetrio Egan, que entregan valiosa información sobre la vida de los campesinos de los Altos de Arica en esa época.

La revisita en realidad finalizaba en Lima cuando la Contaduría Mayor establecía el número de tributarios de cada pueblo y, en consecuencia, la suma del tributo anual. Luego este dato se congelaba hasta una próxima visita. A partir de allí el pago del tributo era una responsabilidad del pueblo o del ayllu en su conjunto y las variaciones negativas debían ser financiadas por el cacique y los recolectores del tributo. Por ello en la revisita es importante el cotejo con los libros parroquiales y certificar las defunciones; de otro modo los muertos debían seguir pagando tributos. En algunos casos esta absurda deuda recaía sobre los tributarios; en otras, el cacique lograba arrendar tierras de reparto a forasteros para cumplir con los tributarios ausentes por muerte o por aquellos que migraron a otros lugares. Estas circunstancias eran particularmente críticas en caso de pestes. Las certificaciones en algunos casos eran fuentes de conflictos, entre las comunidades y los curas que daban fe de estas defunciones, por los excesivos costos de es- 
tas escrituras. En condiciones normales, las defunciones se equilibraban con los nacimientos. Sin embargo, estamos en una época de reformas donde el rendimiento de los funcionarios era evaluado por el aumento de los ingresos fiscales. De modo que, al margen que la población estaba creciendo vegetativamente desde la mitad del siglo XVIII el corregidor se esforzó para que ese crecimiento fuera aún mayor. Cualquier lector va a reparar como la categoría de los 18 años fue abultada, pues es notablemente mayor que las de 15 a 17 o las de 19 a 21. Por años siguieron reclamaciones de quienes se consideraban injustamente incluidos en las categorías de tributarios, especialmente en los casos de cholos y zambaigos que reclamaban para sí la condición de mestizos.

Respecto a la organización y el número de tributarios en 1773, en la Tabla 1 se pueden comparar estos datos con los que ofrece el Sumario de la revisita de Cárdenas en $1756^{14}$ con la revisita de Egan de 1772.

La comparación de 1750 con 1772 muestra un significativo aumento de la población y en prácticamente todos los pisos y pueblos andinos, siendo más significativo ese incremento en los pueblos de la sierra. La caída de la población en Choquelimpie y Caquena, podemos suponer, se debió a la decadencia de los minerales en aquellas áreas, entre 1750 y 1772. Es un dato interesante para explorar los ciclos mineros coloniales de un mineral que carece de investigación.

Respecto a la relación hombres/mujeres se repite un fenómeno general: mayor número de las últimas. En los valles bajos había 80 hombres por cada cien mujeres en 1750 y 95 en 1772 . En la sierra la misma relación era de 72 y 82 y en el altiplano de 81 y 100 . El cambio de la relación entre 1750 y 1772 puede indicar por una parte que ésta se había tornado un tanto más equilibrada, o bien, que Egan se preocupó de contar más a los hombres como potenciales tributarios que a las mujeres. De hecho el aumento de los varones de 1.185 a 1.623 implica un aumento de $37 \%$; en cambio, las mujeres crecen de 1.603 a 1.899 , o sea, en un $18 \%$. Es difícil atribuir esos porcentajes a fenómenos sociales, como una mayor inmigración masculina cuando vemos que los pueblos vinculados a la minería bajan su población; en consecuencia, pareciera que debemos atribuirlo a la "eficiencia" reformista borbónica de Egan. Sin embargo, no debemos atribuir sólo a Egan este duro afán por incrementar los ingresos fiscales. Puede verse que el cacique Cañipa intentó demostrar que debían ser rebajados de la enumeración varios individuos ausentes del cacicazgo enumerados en la revisita de Cárdenas. Recibida la información pertinente de testigos, el defensor de la Real Hacienda aceptó rebajar a uno de los seis ausentes: a Antonio Lupistaca, quien había asesinado a su mujer y había huido (Ver texto adjunto fojas 72v-77r).

Es evidente que la revisita de Codpa de 1772 refleja mejor que la de 1750 las presiones fiscales propias de las políticas de los gobernantes Borbones que en la tesis de Brading apuntaban a una verdadera reconquista de América ${ }^{15}$. La falta de eficacia de la política de los Austrias en el siglo XVII llevó a una crisis de las políticas fiscales hispanas tanto en Europa como en América. Los reyes Borbones y sus ministros trataron de revertir este estado de decadencia organizando un estado más vigilante, mejor informado, con funcionarios de mejor rango, más preparados, con un aparato militar fuerte y organizado, con medidas económicas entre las que destacan los aumentos de impuestos e instituciones mejor reglamentadas y equipadas para hacer efectiva su cobranza, junto a medidas destinadas a favorecer el incremento de las actividades productivas y el comercio. Más tarde llegarán los intentos de mejorar los niveles de instrucción y un discurso ilustrado que penetrará profundamente en las capas criollas y que creará con el tiempo contradicciones con la metrópoli. Sin embargo, había problemas estructurales para organizar una buena administración que evitara la tradicional corrupción de las autoridades. Los salarios fiscales parecían insuficientes para la categoría y el rango que tenían algunos funcionarios, entre ellos los corregidores.

Los corregidores eran figuras claves en la administración de las provincias. Reunían, en una persona e institución, las atribuciones de los poderes del estado; en consecuencia, eran los representantes del Rey en la provincia y con facultades ejecutivas, legislativas, judiciales, militares y policiales. Dado que sus sueldos eran insuficientes se toleró y generalizó desde fines del siglo XVII la práctica que estos funcionarios pudieran vender, de modo forzado, mercaderías a los campesinos andinos y a otros sectores sociales provincianos; es el llamado "reparto forzoso de mercaderías", institución de la cual existe una extensa bibliografía, entre ella se destacan los textos 
Tabla 1: Número de hombres y mujeres de los pueblos de los Altos de Arica o Cacicazgo de Codpa agrupados por valles, sierra y altiplano, 1750-1772.

Number of men and women of the los Altos de Arica and Cacicazgo of Codpa, which are grouped into valley, sierra, and highland, 1750-1772.

\begin{tabular}{|c|c|c|c|c|c|c|}
\hline \multirow[b]{2}{*}{ Pueblos } & \multicolumn{3}{|c|}{$1750^{*}$} & \multicolumn{3}{|c|}{1772} \\
\hline & Hombres & Mujeres & Total & Hombres & Mujeres & Total \\
\hline Umagata & 35 & 35 & 70 & 58 & 55 & 113 \\
\hline Livilcar & 57 & 73 & 130 & 89 & 96 & 185 \\
\hline Sora & 37 & 53 & 90 & 56 & 61 & 117 \\
\hline$\underline{\text { Total Valles }}$ & 129 & 161 & 290 & 203 & 212 & 415 \\
\hline Codpa & 158 & 219 & 377 & 214 & 273 & 487 \\
\hline Pachica & 80 & 70 & 150 & 113 & 105 & 218 \\
\hline Esquiña & 66 & 88 & 154 & 135 & 140 & 275 \\
\hline Timar & 52 & 85 & 137 & 65 & 100 & 165 \\
\hline Tignamar & 69 & 99 & 168 & 70 & 88 & 158 \\
\hline Saxamar & 48 & 57 & 105 & 43 & 60 & 103 \\
\hline Pachama & 52 & 70 & 122 & 81 & 77 & 158 \\
\hline Belén & 161 & 246 & 407 & 207 & 262 & 469 \\
\hline Socoroma & 91 & 140 & 231 & 156 & 204 & 360 \\
\hline Putre & 98 & 144 & 242 & 133 & 175 & 308 \\
\hline Total Sierra & 875 & 1.218 & 2.093 & 1.217 & 1.484 & 2.701 \\
\hline Guallatire & 23 & 27 & 50 & 45 & 52 & 97 \\
\hline Parinacota & 64 & 80 & 144 & 77 & 89 & 166 \\
\hline Choquelimpie & 38 & 47 & 85 & 20 & 20 & 40 \\
\hline Caquena & 56 & 70 & 126 & 61 & 42 & 103 \\
\hline Total Altiplano & 181 & 224 & 405 & 203 & 203 & 406 \\
\hline Total Codpa & 1.185 & 1.603 & 2.788 & 1.623 & 1.899 & 3.522 \\
\hline
\end{tabular}

* Fuente: Hidalgo 1986: 158.

de Tord (1974; 1981), Golte (1976), Moreno (1977) y O'Phelan (1988). De acuerdo con Golte, el "reparto" no fue un abuso más, a pesar de lo cruel que pudo ser su práctica. Fue un sistema destinado a crear un mercado interno susceptible de ser ampliado al aumentar la cantidad y los valores a repartir. No obstante que este sistema fue legalizado entre 1750-1756, muy pronto los corregidores superaron el arancel o listado de mercancías, incluidas las cantidades y precios que podían vender en sus distritos. Con ello, para pagar las deudas generadas por el reparto, se forzaba a los campesinos a vender un porcentaje creciente de sus cultivos, originalmente destinados a la subsistencia familiar y a ofertar su fuerza de trabajo creando posibilidades de crecimiento para la minería, la agricultura de las grandes haciendas y de los obrajes o manufacturas coloniales.

Es razonable entonces que en la perspectiva indígena la queja principal estaba dirigida contra el excesivo "reparto" y otros abusos de los corregi- dores. En el caso de Arica, fueron en contra del corregidor Egan los reclamos más importantes que tenemos registrados, como se aprecia en las denuncias de la mayor parte de los caciques del corregimiento de Arica, en 1776. Aquí sólo deseamos recordar que un año después que Egan había dejado la provincia, el cacique de Tarata, don Pedro Copaja y Ninaja, se quejaba que Egan los había reducido a la condición de esclavos suyos por medio del reparto. En sus cinco años de gobierno, Egan, en vez de hacer un reparto, triplicó ilegalmente la cantidad que tenía autorizada y, además, repartió otras mercaderías que no se incluían en su "arancel". Por los datos entregados por el cacique, el promedio de los campesinos de Tarata empleaba el producto de dos de sus tres "topos" de tierras en el pago de tributo, reparto y demandas eclesiásticas (Hidalgo 1987:216-221). Los líderes étnicos buscaban apoyo en las difíciles situaciones coloniales utilizando las divisiones entre los funcionarios reales. Pedro Copaja encontró aliados en los 
oficiales reales y gracias a ellos pudo sostener un juicio contra el corregidor Egan cuyos resultados finales no conocemos ${ }^{16}$.

Egan merece una nota aparte por las opiniones que expresó en sus proyectos o ensayos. En uno de ellos defiende la necesidad de mantener el reparto y, de paso, critica algunos sectores y prácticas de la sociedad colonial como el excesivo número de fiestas religiosas, sosteniendo que si el reparto no lo hicieran los corregidores lo harían otros sectores como los curas y hacendados. También se pronunció sobre la necesidad de mejorar la defensa interior del reino y de alguna manera previno una rebelión como la de Tupac Amaru que ocurriría un año después de escrito su texto. Por sus opiniones sobre el reparto, el historiador español Alfredo Moreno (1977) le ha dedicado algunas páginas de gran interés. Se trató de un corregidor que por sus escritos y obras podría ser calificado de "corregidor ilustrado". Entre sus escritos está la revisita que comentamos y otras que esperan ser publicadas como las de Tarata e Ilabaya, del mismo modo sus informes para las autoridades virreinales: "Sistema sobre los repartos, 1778" y el "Proyecto para la seguridad interior del reino"17.

El documento adjunto nos aproxima a otro personaje histórico. La revisita de Codpa se inicia en la casa del cacique don Diego Felipe Cañipa, personaje importante por varios motivos. Es el último cacique de un linaje que gobernó los pueblos andinos de los Altos de Arica desde mediados del siglo XVII (Durston e Hidalgo 1999; Hidalgo y Durston 1998). Su presencia es relativamente frecuente en el Achivo Administrativo de Arica así como en el Judicial de Arica en el Archivo Nacional de Chile. Su nombre está también en la notable campana de bronce que posee una leyenda con su dedicatoria, en la hermosa iglesia de Livilcar, pueblo de su familia y donde aun habitan algunos de sus descendientes ${ }^{18}$. En el índice onomástico pueden verse todas las referencias a este cacique en el texto de la revisita, incluida la declaración de sus bienes. Siete años después, en 1781, Cañipa fue ejecutado en Codpa por mantener su fidelidad a la corona española frente a los partidarios de Tupac Amaru que lo urgían a unirse a sus fuerzas (Hidalgo 1986:199). Cañipa siguió la línea de casi todos los caciques de Arica y Tarapacá, en tanto los campesinos participaron activamente en la rebelión.

En los años setenta, el primer autor se encontró con la revisita de Codpa de 1773 en el Archivo
Departamental de Tacna y, gracias a la gentileza del Dr. Luis Cavagnaro, entonces director de ese archivo, me fue permitido hacer una fotocopia. La intención era publicarla a la brevedad. Sin embargo, nuestro colega e inolvidable amigo Franklin Pease, unos días antes se había encontrado con el mismo texto y me informó de ello al visitarme en Arica. Acordamos que la revisita de Codpa debía publicarla él. Por razón de sus numerosas obligaciones, Franklin no alcanzó a hacerlo y sentimos que cumplir con esta tarea es un homenaje póstumo al amigo y al gran historiador.

Junto a ello, cuando en 1978 publicamos Revisita a los Altos de Arica en 1750 escribimos en el primer párrafo de la introducción lo siguiente:

"El documento histórico que publicamos acá, seguramente, será de interés para los habitantes de los pueblos del interior de Arica, porque podrán encontrar en él los nombres y edades de sus ancestros a mediados del siglo XVIII. No se trata de un árbol genealógico, pero sí de una visión global en un momento del pasado colonial de lo que fue el cacicazgo o repartimiento de Codpa, de los Altos de Arica" (Hidalgo 1978: I).

Fue nuestro primer objetivo que ese documento fuera de interés para la población actual de los Altos de Arica, por ello aun cuando esa revisita ha sido extensamente citada por especialistas nos ha resultado aún más grato saber que también ha sido de utilidad para los descendientes de los aymaras del siglo XVIII. La comunidad indígena de Tignamar nos señala en una carta del 17 de febrero de 2003 cómo ese documento les ha servido para recuperar territorios cuyos títulos se remontaban a 1758 , y que incluyen pastizales, vegas, cerros, pampas y quebradas. Sus representantes enfatizan la necesidad de documentos coloniales para establecer la "exactitud del universo real denominado COMUN DE LOS INDIOS DEL PUEBLO DE TIGNAMAR... Por tal motivo, necesitamos urgentemente si usted nos puede enviar antecedentes e información de lo [que] fue la revisita del año 1773 (...) nos servirá una enormidad para conocer con exactitud de qué troncos de familias venimos, quiénes desaparecieron y quiénes se incorporaron a través del tiempo hasta la fecha actual, que hoy forman la comunidad de Ticnamar:

"Una vez más, señor Hidalgo, le reiteramos nuestros infinitos agradecimientos, el habernos dado la oportunidad de leer su libro publicado el año 1978, sobre lo que fue el pasado colonial del 
cacicazgo de Codpa, del cual ahora podemos decir con orgullo que tenemos un pasado histórico y recuperar nuestra identidad aymara". Firman la carta: Eduardo Subieta Tarqui, secretario, y Oscar Omar Mena Mena, presidente.

Don Eduardo y don Oscar nos han impuesto después de su carta una grata tarea, pues si bien la investigación histórica para nosotros ha sido un placer más que una obligación, conocer el interés y utilidad que tienen estos documentos rescatados de los archivos para los amigos andinos es un gran incentivo adicional.

Finalmente, en la transcripción del documento, se trató de seguir el texto lo más fielmente posi- ble y sólo se desarrollaron las abreviaturas agregando en negrilla las letras que faltaban en cada palabra. El texto de la revisita fue foliado en tiempos recientes, seguramente por algún funcionario del archivo; tenemos la sospecha, sin embargo, que falta una foja entre la 13 y la 14. El documento que publicamos fue ubicado, como hemos señalado, por el primer autor, y Nelson Castro y Soledad González han tenido la responsabilidad de su transcripción y la elaboración de los índices toponímico, onomástico y el índice general. En el índice onomástico se han incluido sólo los nombres de aquellas personas que aparecen con algún rasgo particular.

\section{Referencias Citadas}

\section{Fuentes manuscritas}

a. A.A. (Administrativo de Arica, Archivo Nacional de Chile) Legajos 4, 3 .

b. A.D.T. (Archivo Departamental de Tacna, Perú)

Legajo 1.

c. A.G.I. (Archivo General de Indias, Sevilla)

Audiencia de Lima, 895, 1002.

d. C.R.A. (Cajas Reales de Arica, Escuela de Derecho, Universidad de Chile, Santiago) Volumen 3.

\section{Fuentes publicadas}

Hidalgo, J.

1978 Revisita a los Altos de Arica en 1750. Universidad del Norte, Arica.

Málaga Medina, A.

1974 Visita General del Perú por el Virrey A. Francisco de Toledo, 1570-1575, Arequipa. Imp. Edit. “El Sol”, Arequipa. 1841 Recopilación de Leyes de los Reinos de las Indias. Mandadas imprimir y publicar por la Magestad Católica del Rey Carlos II, 4 Vols. Imp. Edit. "El Sol”, Madrid.

\section{Obras secundarias}

Aróstegui, J.

2001 La Investigación Histórica: Teoría y Método. Crítica, Barcelona.

Brading, D.A.

1975 Mineros y Comerciantes en el México Borbónico (1763-1810). Fondo de Cultura Económica, México.

1990 Capítulo 3. La España de los Borbones y su imperio americano. En Historia de América Latina, Vol. 2. América Latina Colonial: Europa y América en los siglos XVI, XVII, XVIII, editado por L. Bethell, pp. 85-126, Editorial Crítica, Barcelona.

Céspedes del Castillo, G.

1946 La Visita como Institución Indiana. Anuario de Estudios Americanos Tomo 3:984-1025.

Cúneo-Vidal, R.

1977 Historia de los Cacicazgos Hereditarios del sur del
Perú. Obras Completas, Tomo I. Editor: Ignacio Prado Pastor, Lima.

Durston, A. y J. Hidalgo

1999 La presencia andina en los valles de Arica, siglos XVI-

XVIII: casos de regeneración colonial de estructuras archipielágicas. Chungara 29:249-273.

Gade, D.

1991 Reflexiones sobre el asentamiento andino de la época toledana hasta el presente. En Reproducción y Transformación de las Sociedades Andinas siglos XVI-XX, compilado por S. Moreno y F. Salomón, pp. 69-90. Ediciones Abya-Yala, Quito.

Golte, J.

1976 Redistribución y Complementariedad Regional en la Economía Andina del Siglo XVIII. Berlín.

1980 Repartos y Rebeliones, Tupac Amaru y las Contradicciones de la Economía Colonial. Instituto de Estudios Peruanos, Lima.

Guevara-Gil, A. y F. Salomon

1994 Personal visit: colonial political ritual and the making of Indians in the Andes. Colonial Latin American Review 3:3-36.

Hidalgo L., J.

1986 Indian Society in Arica, Tarapacá and Atacama, 17501793, and its Response to the Rebellion of Tupac Amaru. Tesis de Doctorado, Universidad de Londres.

1987 Tierras, exacciones fiscales y mercado en las sociedades andinas de Arica, Tarapacá y Atacama, 1750 - 1790. En La Participación Indígena en los Mercados Surandinos Estrategias y Reproducción Social Siglos XVI-XX, editado por O. Harris, B. Larson, E. Tandeter, pp. 193-231. Ceres, La Paz. 1997 Los yungas de Tarata en el siglo XVIII. En Antropología, Arqueología e Historia de los Andes. Homenaje a María Rostworowski, pp. 425-442. Instituto de Estudios Peruanos, Lima.

Hidalgo, J. y A. Durston

1998 Reconstitución étnica colonial en la sierra de Arica: El cacicazgo de Codpa, 1650-1780. Actas del IV Congreso Internacional de Etnohistoria, Tomo II, pp. 32-75. Pontificia Universidad Católica del Perú, Fondo Editorial, Lima. 
Lynch, J.

1989 Las Revoluciones Hispanoamericanas 1808-1826. Nueva edición ampliada y puesta al día, Editorial Ariel S.A., Barcelona.

Mayer, E.

1972 Censos insensatos: evaluación de los censos campesinos en la historia de Tángor. En Visita de la Provincia de León de Huanuco en 1562 Iñigo Ortiz de Zúñiga, Visitador, Tomo II, editado por J. V. Murra, pp. 339-365. Universidad Nacional Hermilio Valdizan, Huanuco.

Moreno C., A.

1977 El Corregidor de Indios y la Economía Peruana en el Siglo XVIII. Instituto Gonzalo Fernández de Oviedo, Madrid.

O'Phelan G., S.

1988 Un Siglo de Rebeliones Anticoloniales, Perú y Bolivia, 1700-1783. Centro de Estudios Rurales Andinos "Bartolomé de Las Casas", Cuzco.

Saignes, $\mathrm{T}$.

1989 Lobos y ovejas: formación y desarrollo de los pueblos y comunidades en el sur andino (siglos XVI-XX). En Reproducción y Transformación de las Sociedades Andinas siglos XVI-XX, compilado por S. Moreno y F. Salomon, pp. 91-135. Ediciones Abya-Yala, Quito.
Sánchez-Albornoz, N.

1978 Indios y Tributos en el Alto Perú. Instituto de Estudios Peruanos, Lima.

Santoro, C. y L. Ulloa (editores)

1985 Culturas de Arica. Universidad de Tarapacá, Serie Patrimonio Cultural Chileno. Colección Culturas Aborígenes. Departamento de Estudios Culturales del Ministerio de Educación, Santiago.

Spalding, K.

1974 De Indio a Campesino: Cambios en la Estructura Social del Perú Colonial. Instituto de Estudios Peruanos, Lima.

Tord, J.

1974 El corregidor de indios del Perú: comercio y tributos. Historia y Cultura 8: 187-198.

Tord, J. y C. Laso

1981 Hacienda, Comercio, Fiscalidad y Luchas Sociales (Perú Colonial). Biblioteca Peruana de Historia, Economía y Sociedad, Lima.

Villalobos, $\mathrm{S}$

1981 Revisita de los indios del Corregimiento de Arica en 1753. Revista Chilena de Historia y Geografía 148:68-84.

Zapater, $\mathrm{H}$.

1973 Los Aborígenes Chilenos a Través de Cronistas y Viajeros. Editorial Andrés Bello, Santiago.

1976-77 Cinco relaciones sobre San Pedro de Atacama. Norte Grande 5:49-63.

\section{Notas}

1 Esta publicación fue preparada originalmente como parte del proyecto FONDECYT 1.000.089; sin embargo, en la actual versión se introdujeron cambios importantes en la introducción así como en la transcripción del texto de la Revisita y, consecuentemente, en los índices. Todas estas tareas han sido realizadas como parte del Proyecto FONDECYT 1.030.020 "Historia de los pueblos andinos de Arica, Tarapacá y Atacama: Colonización, etnogénesis e ideologías coloniales. Siglos XVI- XVIII".

2 Julio Aróstegui plantea una interesante crítica a los planteamientos de Ortega, véase Aróstegui (2001:229).

3 Horacio Zapater (1973: 9) señala que para estudiar la cultura indígena en algunas regiones apartadas o marginales, especialmente las australes, donde el proceso cultural europeo estaba en sus inicios se pueden utilizar crónicas del siglo XVIII de una manera equivalente a una del siglo XVI. Más adelante en 1976-77 comparando los datos de Vivar con los aportados por Philippi concluye que "los modos de vida en tres siglos habían experimentado en San Pedro [de Atacama] relativamente pocos cambios" (Zapater 1976-77: 52).

4 Ver Hidalgo y Durston (1998) y Durston e Hidalgo (1999). Cúneo Vidal (1977) planteó el origen colonial del Cacicazgo de Codpa, pero su análisis siguió más bien un carácter genealógico.

5 Carta del Capitán Juan Maldonado Buendía al Rey, La Plata, 25 de mayo de 1575, A.G.I. Audiencia de Lima, Leg. 123. Citado por Alejandro Málaga Medina (1974).

6 Gade (1991) y Saignes (1991).

7 Para una visión amplia e histórica de la "Institución Visita”, puede verse el texto de Guillermo Céspedes del Castillo (1946), quien diferencia y distingue residencias, visitas y pesquisas entre los instrumentos jurídicos que permitían a los soberanos castellanos ejercer su derecho de "inspeccionar la actuación de los organismos gubernativos y funcionarios públicos" (página 984), así como la transformación de la institución visita en Indias. Villalobos (1981) revisa el tema de la visita y revisita de indios en el Perú desde el siglo XVI desde la perspectiva de los objetivos de la administración hispana.

8 Véase Enrique Mayer 1972.

9 Véase la Provisión de Visita, Lima 14 de diciembre 1772, con las instrucciones que debía seguir Egan en la Revisita de [los Altos de] Arica, entre las fojas 1r a 6v en el texto adjunto.

10 El tema de los forasteros ha sido ampliamente estudiado en diversas áreas y desde diversos puntos de vista; véase, por ejemplo, Nicolás Sánchez-Albornoz (1978), como un indicador de las transformaciones sufridas por las comunidades andinas coloniales, y a Jurgen Golte (1980) para una discusión sobre su influencia en las rebeliones andinas del siglo XVIII.

11 Véase Spalding (1974).

12 Véase la reinterpretación del documento "visita" en Guevara y Salomon (1994).

13 Céspedes (1946: 1000) aclara que el visitador "no podía escoltarse de soldados, posible amparo de vejaciones y abusos".

14 Sumario de la revisita de los repartimientos del Corregimiento de Arica por el Oficial Real Joaquín Xavier de Cárdenas, Tacna 27 de agosto de 1756, en libros de la Cajas Reales de Arica, Vol. 3, f 213r-f 221r. Instituto de Historia y Bibliografía, Escuela de Derecho, Universidad de Chile, Santiago. Este documento ha sido publicado por Villalobos (1981) 
15 Véanse Brading ( [1971] 1975, 1990) y Lynch (1989).

16 Véanse: a) Archivo General de Indias, Sevilla, España (de aquí en adelante: A.G.I.), Lima 895 "Los oficiales reales de Arica v/s Egan", Arica 1776.

b) A.G.I., Lima 895 "Los Oficiales Reales de Arica... representan a V.M. los inconvenientes que ocurren de la asistencia de los corregidores...", Arica, 1777.

c) Archivo Nacional de Chile, Administrativo de Arica, (de aquí en adelante: A.A), Leg. 4, "Razón de los repartos que hizo el Corregidor don Demetrio Egan”, Arica, 1778.

17 Véanse: A.A. Leg. 3, Revisita de Ilabaya de D. Egan, 1773. A.A. Leg. 4, Revisita de Tarata de D. Egan, 1773-74.

Archivo Departamental de Tacna, leg. 1 C. 8 , año 1772.
Revisita de Codpa de D. Egan, 1772.

A.G.I: Lima 1002. Copia del dictamen sobre los repartos que dio el Coronel don D. Egan al Exc. señor don Manuel Guirior, virrey del Perú en el año 1778.

A.G.I. Lima 1002, "Proyecto que propone... D. Egan para la seguridad interior del Reino”, 1779.

18 Véase en Santoro y Ulloa (1985: 91) fotografías de la Iglesia y Campana, en esta última se lee la fecha de la fabricación y donación de la campana 1779. Las fotografías citadas fueron tomadas por el primer autor de esta introducción con ocasión de una visita al pueblo de Livilcar realizada con Calogero Santoro hace unos 20 años. 
Comunidad Indígena Aymara

de Ticnamar. Pers. 24 Ley 19.253

OFICIO N $104 *$

Ref. - Solicita Información de Revisita

A los Altos de Arica, año 1773

ARICA, 17 de Febrero del 2003

Señor

Jorge Hidalgo L.

Los Agustinos 5315

Comuna Nuñoa - Santiago

Muy respetado señor:

Por la Presente, en nuestra calidad de representantes de los Comuneros del Pueblo de Ticnamar y Comunidad Indigena, reciba en primer término los más sinceros saludos y agradecimiento a tan loable labor al estudio antropologico que Ud. dirige en lo profesional.

Nuestra Comunidad, ha poseido en uso y goce ancestralmente, hasta el dia de hoy en forma tranquila y pacífica, los territorios de la Propiedad denominada "DIEGO APASA Y EL COMUN DE INDIOS DEL PUEBLO DE TICNAMAR", ellos fueron los titulares del inmueble.

Antecedentes que se sustentan en la Compraventa que data del año 1758, pasando por los años 1773, 1856 y en Registro Chileno, despues de la Guerra del Pacifico, en los años 1903, 1909 y 1944, propiedad inscrita y reinscrita que rola a fojas $56 \mathrm{~N}^{\circ} 55$ del Registro de propiedad del C.B.R. de Arica.

A pesar de estar bien inscrita la propiedad, en diferentes épocas nos ha traido conflictos entre comuneros por intereses personales de querer vulnerar los derechos de los demás, arrogandose derechos y acciones de poseciones y sucesiones, debido que los Títulos estaban perdidos ( Archivo Nacional ), recien en el mes de Sep.del 2000, se encontraron los documentos despues de una búsqueda esteril en el Archivo de Tacna ( Peru ), en la Oficina de B. Nacionales no tenian antedtes., pero se pagaban contribuciones, que no indicaban nada con su rol.

Sin embargo, con todo los documentos a la vista, todavía hay un grupito de comuneros, que insisten de un modo de avivamiento quedarse con los Territorios ( Pastales, Vega, Cerros, Pampas y Quebradas ), han recurrido a los Tribunales de Justicia, en las cuales veremos los resultados judiciales, despues de una contensiosa oposición y esperamos que Comunidad saldra beneficiada a travez de una sentencia judicial o avenimiento de reconcilación.

Para que ocurra este milagro, el Sr. Coservador de B. Raices de Arica, recomienda que debe hacerse los estudios históricos, sociológicos, antropológicos, genealógicos y jurídicos del título, que el caso requiere y se precise con exactitud el universo real del denominado "COMUN DE INDIOS DEL PUEBLO DE TIGNAMAR", desde el referido año 1758, pasando por los años 1773, 1856, 1903,1909 y 1944, hasta la fecha actual, determinandose consecuentemente quienes al dia de hoy tienen derecho sobre dichas Tierras y cuales son sus cuotas o partes alícuotas en esta gran comunidad territorial.

Tambien, aconseja el Sr. Conservador, que la Ley Indígena $N^{\circ} 19.253$, debe inscribirlo en el Registro de Tierras indígenas, para protegerlo y fomentar su desarrollo, estos tramites se hizieron, pero hubo oposición de los otros recurrentes.

\footnotetext{
* Carta transcrita textualmente donde se respetó la escritura original.
} 
Por tal motivo, necesitamos urgente si Ud. nos pueda enviar antecedentes e información de lo fue la Revisita del año 1773, solo en lo que es de Tignamar, documentos conjuntamente con lo de 1750, nos servirá una enormidad para conocer con exactitud que troncos de familias venimos, quienes desaparecieron, y quienes se incorporaron a travez del tiempo hasta la fecha actual, que hoy forman la Comunidad de Ticnamar.

Somos una Comunidad Indígena Aymara, un poco ignorante en documentos historicos, juridicos y otros, pero algo hemos aprendidos y hasta podemos defendernos, nos sirvio de mucho el andar en la búsqueda de los papeles, llegando a Ud. Sr. Hidalgo, que esperamos su ayuda y se lo agradeceremos de corazón, si hay una posibilidad de ponernos en contacto con alguna institución o universidad.

Una vez más Sr. Hidalgo, le reiteramos nuestros infinitos agradecimientos, el habernos dado la oportunidad de leer su libro publicado el año 1978, sobre lo fué el pasado colonial del casicazgo de Codpa, del cual ahora podemos decir con orgullo que tenemos un pasado historico y recuperar nuestra identidad aymara.

Le saludamos muy Atte.

\section{Eduardo Subieta Tarque \\ Secretario}

\author{
Oscar Omar Mena Mena \\ Presidente
}

Hay firmas. 


\section{Índice General de \\ La Revisita de Codpa (altos de Arica) de 1772-1773 del corregidor \\ Demetrio Egan}

Decreto

Decreto de Provisión de Revisita

Auto de Obedecimiento

Auto de notificación a los oficiales de las Cajas Reales

Auto

Carta exortatoria al Juez Eclesiástico de la Doctrina de Codpa

Edicto de revisita dirigido al cacique, principales y común de indios

Notificación de Edicto

Padrón de San Martín de Codpa y Ayllu de Collana

Casa del Cacique

Ayllu Collana

Ayllu de Capanique

Padrón del Pueblo de Pachica

Padrón del Pueblo de Esquiña

Padrón del Pueblo de Timar

Padrón del Pueblo de Tignamar

Padrón del ayllu de Guallatiri

Padrón del Pueblo de Sacsamar

Padrón del Pueblo de Pachama

Padrón del Pueblo de Vmagata

Padrón del Pueblo de Libilca

Padrón de los ayllu del Pueblo de Belén

Ayllu de Mancasaya

Ayllu de Aransaya

Padrón del Pueblo de Socoroma

Padrón del Pueblo de Sora

Padrón del pueblo de Putre

Padrón del pueblo de Parinacota

Originarios del Asiento de Choquelimpe

Padrón del ayllu de Caquena

Resumen general

Registro de fallecidos (especificados por pueblo)

Interrogatorio por indios ausentes

Bienes del cacique

Informe final fs. $1 \mathrm{v}-2 \mathrm{r}$

fs. $2 r-7 r$

f. $7 \mathrm{r}-\mathrm{v}$

f. $7 v-8 r$

f. $8 \mathrm{r}-8 \mathrm{v}$

fs. $11 \mathrm{r}-\mathrm{v}$

fs. $12 \mathrm{r}-\mathrm{v}$

fs. $12 \mathrm{v}$

f. $13 \mathrm{r}$

f. $13 \mathrm{r}$

fs. $13 \mathrm{r}-15 \mathrm{v}$

fs. $16 \mathrm{r}-19 \mathrm{v}$

fs. $19 v-22 v$

fs. $22 \mathrm{v}-26 \mathrm{v}$

fs. $26 \mathrm{v}-29 \mathrm{r}$

fs. $29 \mathrm{r}-31 \mathrm{r}$

fs. $31 \mathrm{r}-32 \mathrm{v}$

fs. $32 \mathrm{v}-34 \mathrm{r}$

fs. $34 \mathrm{r}-36 \mathrm{v}$

fs. $36 \mathrm{v}-38 \mathrm{v}$

fs. $38 \mathrm{v}-41 \mathrm{r}$

fs. $41 \mathrm{r}$

fs. $41 r-45 r$

fs. $45 \mathrm{r}-48 \mathrm{r}$

fs. $48 r-53 r$

fs. $53 \mathrm{r}-54 \mathrm{v}$

fs. $54 \mathrm{v}-59 \mathrm{r}$

fs. $59 \mathrm{r}-61 \mathrm{r}$

fs. $61 \mathrm{r}-62 \mathrm{r}$

fs. $62 \mathrm{r}-64 \mathrm{r}$

fs. $64 \mathrm{r}-68 \mathrm{v}$

fs. $68 v-73 r$

fs. $73 \mathrm{r}-77 \mathrm{r}$

fs. $77 \mathrm{r}$

fs. $77 \mathrm{r}$ 
[Ficha descriptiva de la pieza en el: Archivo Departamental de Tacna

Serie Corregimiento/Subdelegación Gobierno, Legajo 1, Cuaderno 8, Año 1772]

"Revisita y numeración de los indios de Codpa, con sus aillos de Capanique, Pachica, Esquiña, Timar, Tignamar, aillo Guallatiri, Sacsamar, Pachama, Umagata, Livilcar, Belen, aillo Mancasaya, aillo Anansaya, Socoroma, Sora, Putre, Parinocota, asiento de Choquelimpe, aillo Caquena, todos pertenecientes a la Doctrina de Codpa, en los altos de Arica. Se inicia con pedimento para que se den las instrucciones. Se otorga tal información, al Corregidor de Arica don Demetrio Egan. Constan entre otras informaciones el cargo cacical la edad, la vinculación parental con la cabeza de familia, el origen y la posesión de tierras, así como el estado civil. Concluye la revisita con una información de los libros parroquiales de los lugares visitados y la información de los contribuyentes muertos después de la anterior visita"

\section{Revicita General Egan Codpa}

1772

Don Manuel Amat y Juniet Cavallero del Orden de San Juan del consejo de su Magestad Gentil Hombre de su Real Camara con entrada Theniente General de sus Reales Exercitos Virrey Governador y Capitan General de estos Reynos Provincias del Peru y Chile etc. Por quanto, el Correxidor de la Provincia de Arica, en carta de quinze de Enero de este presente año me hiso presente, que haviendo reciuido orden de este Superior Govierno, para dar principio a la Revicita de dicha Provincia, y no encontrado la Ynstruccion que deve obserbar entre los papeles de su antesesor estaba prompto a principiarla, siempre que reciviese dicha Ynstruccion, que por Decreto de veinte y quatro de febrero de dicho año, Mande informase el Contador de Retazas, y con el que hiso en veinte y seis de Marzo del expresado año di vista a los Señores Fiscal y Fiscal Protector con cuyas respuestas por otro de siete de Abril del mismo año /foja 1v/ Mande se escribiese carta al expresado Correxidor de Arica con arreglo al Ynforme del expresado Contador de Retazas, incluiendole un ejemplar de la Ynstruccion impresa que dijo el Señor Fiscal cuia carta en efecto se escrivio por mi Secretaria de Camara, con inclucion al sitado exemplar. En este estado el presitado Correxidor por otra Carta de veinte y ocho de Junio del mismo año acuso resivo de la Ynstruccion Methodica que se le remitio, añadiendo, que para practicar la revicita le era necesario se le despachase la Provicion Ordinaria; y haviendo pedido Ynforme al Contador de Retazas por Decreto de veinte y ocho de Julio, lo executo, con fecha de veinte, y nuebe de Agosto que el tenor del sitado Decreto de siete de Abril ultimo Ynforme del Contador de Retazas Decreto por mi proveido con pareser del Señor Doctor Don Jossef Perfecto de Salas Abogado de esta Real Audiencia Fiscal de la del Reyno de Chile, mi Asesor General; y de los Capitulos contenidos en la Ynstruccion Methodica expedida por este Superior Govierno, para que sirba de regla a los Jueses

Decreto revicitadores es como se sigue $=$ Lima siete de Abril de mil setecientos setenta y dos: Escribase carta al Correxidor de Arica, con arreglo al Ynforme del Contador de Retazas incluiendole un exemplar de la Ynstruccion impresa que dice el señor Fiscal= Una rubrica de su Exselencia /foja 2r/ Sanz= Otra rubrica $=$ Exselentizimo Señor. Enterado del contenido de esta carta de don Demetrio Egan, actual Correxidor de la Provincia de Arica en quanto a la falta que nota de la Provicion ordinaria de Revicita, para poderla principiar en su Distrito, sobre que me manda Su exselencia Ynformar por su superior Decreto de veinte y ocho de Julio proximo pasado en su puntual cumplimiento el que debo haser se reduse a reproducir el que tiene hecho esta Contaduria con fecha de veinte y seis de Marzo de este año, en que se inserto otro anterior con la de tres de Noviembre del inmediato antesedente de setecientos setenta y uno de resulta de lo que en la materia expuso a Su exselencia, lo que fuere mas de su Superior agrado. Contaduria de Retazas, y Agosto veinte y nuebe de mil setecientos setenta y

Decreto dos= Don Juan Jossef de Leuro= Lima catorze de Septiembre de mil setecientos setenta y dos= Guardese lo prevenido por Decreto de siete de Abril de este año de mil setecientos setenta y dos, librandose la Provicion Ordinaria $=$ Una rubrica

Titulo $1^{\circ}$ de su Exselencia $=$ Sanz $=$ Otra rubrica $=$ Que luego que reciban la Provicion de Revicita, a su

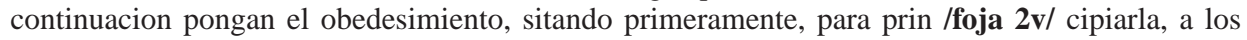
oficiales Reales de la Caxa del Partido a los encomenderos que subcistieren en el distrito de la Provincia que fueren interesados en los Tributos que pagan los Yndios, y a los Mineros del Asiento y Mineral a quien estan destinados para que todos en Perzona, o por Apoderado de sus respectibas, satisfacciones concurran a la expresada actuacion haciendo

constar en los Autos originales estas diligencias $=$ Que en caso de proseder de los suso dichos con morosa lentitud en el nombramiento de Persona que sostituya la suya, se pase de oficio a elegirla a su costa haciendolos de ello inteligentes para que les pare el perjuicio que huviere lugar en derecho y que por su descuido, o negligencia, no se difiera la importante diligencia de la Revicita, causando de este modo los referidos nombramientos, que han de subseguir a las anteriores 
actuaciones $=$ Que se siten tambien al Governador, Casiquez, y Principales de los Yndios de cada repartimiento, para que se hallen presentes, asi a la revicita, y Numeracion, como a todos los demas actos que se hicieren en prosecucion de

ella= Que para la dicha actuacion, se nombre Escrivano, que sea Publico o Real, y no haviendolo en la Provincia, lo execute el Juez ante si, y con testigos, un Alguacil maior un Defensor de los Yndios, si no lo huviere en el Distrito electo por el Superior Govierno: Un Ynterprete solamente, no siendo dos las Lenguas

/Foja 3r/ y ultimamente un Amanuense= Que respecto de que segun dispocicion del Exselentissimo Señor Toledo el Escribano gosa tres pessos un real diarios de asignacion fuera de las costas prosesales: El Alguacil maior quatro pessos: El Defensor de Yndios dos pessos: el Corregidor revicitador del mismo ramo de tributarios, aucilie a los dichos operarios con la dos tercias partes de sus respectibas asignaciones, reservandoles el resto para que lo perciban, quando venidos los autos originales a este Superior Govierno, se le liquide en la Contaduria General de retasas por tasasion formal siendo obligado el Corregidor revicitador a dar cuenta separada, con resibos autenticos, de los que ha contribuido que se le abonara por los ofiziales reales de la Caja del Partido en los enteros que haga del expresado ramo de

tributarios $=$ Que para que la Real Hazienda no sea perjudicada, demorandose estudiosamente la Revicita sea obligado el Juez a concluirla dentro del presiso termino de seis meses con el apercebimiento de que cumplido este no se la abonara lo que diere por pagado a los Ministros actuarios, y que sera obligado a finalisarla de su cuenta, siendo esta omicion de formal capitulo de residencia conforme a ordenansa, reintegrandosele a su magestad, lo que por esta cauza huviere dejado de percibir; pues en atencion a la entidad de la Provincia se concidera el expresado tiempo / foja 3v/ suficiente, para que pueda concluirse la mencionada diligencia de revicita= Que al ofizial real que en calidad de Defensor de real Hazienda asistiese a la Numeracion se le abonen los doscientos mil maravedis cada año que le estan concedidos por la Ley quarenta y quatro del titulo quatro, Libro ocho, quando salgan a negocios del real servicio: y que esto mismo se le contribuya al sujeto que sostituya su poder quando sea forzoso elegirlo por embarazos de su ministerio; bien entendiddo que la expresada ayuda de costa se ha de entender al tiempo que durare la revicita unicamente, y con

respecto a su importe anual= Que se requiera a los Doctrineros, y curas respectibos de cada repartimiento a que entreguen los Libros de Baptismos, y Entierros que tuvieren; y que con ellos concurran a la Numeracion por si, o por

su Theniente $=$ Que les manden y apremien a los Casiquez a que exhiban el Padron de la Revicita antesedente y la ultima Retaza por donde pagan sus tributos y caresiendo de estos Documentos manifiesten las Listas que tuvieren para la cobransa de tributos, para que puedan traerse a cotejo con los Libros de los Curas, y se benga a conocimiento de los que han muerto, y han nasido; de modo que no se oculten Yndios algunos sino que se numeren todos efectibamente so pena de que en caso de ser descubierto lo contrario, se les pribara de sus

ofizios, y que seran castigados con rrigor= Que /foja 4r/ a qualquier Yndio aunque sea particular se le ofresca que sera Principal, o Casique de los que

manifestare que esten ocultos $=$ Que el auto que se probeyere en rrazon de lo referido, a mas de notificarlo a los dichos Casiquez se publique por Bando en Junta general de Yndios, en el Pueblo principal cabesa del repartimiento para

que llegue a noticia de todos= Que evacuadas las expresadas diligencias y señalado dia para principiar la revicita con citacion de todos los interesados para que concurran se comienze por el Pueblo o Ayllo que paressiere mas combeniente, traiendo a la vista el Patron o Libros de Baptismos para aberigura el numero de los Yndios que habya al tiempo de la revicita anterior del Ayllo, y

los que consta haver nacido despues de ella= Que se abra la Numeracion con el Principal del Aillo, y su Muger si la tuviere, y sus hijos a cada uno con sus Edades; sacando al un Margen la de los barones, y al otro la de las Embras prosiguiendo en la mis [ma] orden con los demas casados del Ayllo hasta que se acabe; y luego distintamente se pondran los Viudos con su[s] Hijos, e Hijas los Solteros, y los Reserbados de Tributos por tener cinquenta años de edad, o por otras enfermedades que los inposibiliten de trabaxar, o finalmente por Proviciones particulares del superior Govierno todos con sus Mugeres e Hijos, y

sus Edades en la forma dicha= Que despues de practicado todo /foja 4v/ lo expresado se ponga la numeracion de las Mugeres Viudas, y solteras con sus Hijos e hijas, y al fin de todas los Huerfanos Menores de Diez y ocho años que no tengan Padres vivos; con adbertencia de que el que estuviese casado sin haber cumplido la Edad referida, es tributario, y se ha de poner con los demas en su lugar= Que al fin de la revicita hecha en cada repartimiento, se ponga memoria de los Yndios muertos, y ausentes con expesificacion del tiempo, o parte donde murieron los unos, y la causa de la dicha 
ausencia de los otros autorisada esta con la firma de sus respectibos Curas; y si se hallaren mas Yndios de los contenidos en el Padron y Libros de Baptismos se pondran por nuebamente manifestados en su lugar= Que respecto de que en la clase de ausentes hay diversidad, porque de unos se saue el Lugar donde residen, y las Justicias de el son obligados a darles a los Casiquez, y Cobradores todo el aucilio para cobrarles sus tributos, y que tengan entendido que la fuga no les ha de servir de alivio, y de los otros se ignora absolutamente su paradero separadamente se numeren con esta distincion y de tal suerte que no se contrabengan a lo prebenido por la Ley quarenta y quatro del titulo sinco Libro seis de las recopiladas= Que en casso de haber tomado los Yndios diverso nombre de aquel que se les dio en el Baptismo, y que esto ha de ocacionar confucion para el cotexo: que se haga prolixa aberiguacion de ello de manera que conste con cla

/Foja 5r/ ridad y distincion= Que si algun Yndio para no ser enumerado entre los tributarios alegare ser Mestiso ofreciendo dar Ynformacion despues de haberlo numerando en el Pueblo, o Ayllo donde se hallare, se le reciba con citacion del Casique su comun Defensor de la real Hacienda, e Ynteresados en las Mitas, sin excederse en Declararlo por libre respecto de ser esta facultad privatiba al Superior Govierno donde se deberan remitir las Diligencias, o entregarselas a la parte sin agregarla a los autos de revicita, no entendiendose esto con que estuvieren en posecion de tales Mestisos= Que si huviere algunos cholos cuyo misto se procrea de Mestiso e Yndio o viseversa, hauidos en Matrimonio, o fuera del se numeren tambien separadamente respecto de que estan sujetos a la paga de tributos aunque esentos de la Mita, y servicios perzonales, sin omitir expesificacion de sus Edades Mugerez e hijos= Que igualmente se empadronen en el numero de tributarios, por serlo segun Ley recopilada, los que se titulan Sambaigos que son los que dimanan de Negro e Yndio o viseversa= Que si huviere mediado mucho tiempo desde la actuacion de la ultima Revicita, y que no se encuentren en el devido orden los Libros de Baptismos para venir a conocimiento de los que despues de esta han nacido se manejasen por los Padrones de Con /foja 5v/ feciones de los Curas, y por los anuales que se huvieren hecho para la Cobransa de tributos= que se hayan de distinguir forsosamente las clases de los Yndios assi originarios como forasteros, para que puedan cargarseles, a cada vno su respectiba quota poniendo separacion los dichos Forasteros que gosan Tierras, por si o por sus Mugeres de

aquellos que absolutamente no las tienen= Que se obserbe el metodo expresado en la numeracion de cada repartimiento de los que componen la Provincia, y assi concluida se provea vn auto mandando a los Casiquez que justifiquen con recaudos autenticos los que huvieren dado por muertos y ausentes, reciviendoles Ynformacion de testigos con citacion del Defensor de Real Hazienda; para la qual se les señalara vn termino competente que no hasiendolo dentro del se pondra por tributario como los demas, cuyas diligencias se practicaran con todas las que se concideren conducentes a que no haya fraude alguno en la materia= Que precedidas las dichas actuaciones se provea otro Auto dandoles traslado de dicha Revicita; para que si tuviesen que pedir contra ella, lo hagan en el termino que se les señalare, en la inteligencia que pasado este prescrivira qualquiera accion, y se embiaran los Autos al Superior Govierno, para que resuelva lo que

mas combenga $=$ Que a la final de cada repartimiento se ponga un expecifico o individual resumen de los Pueblos Ayllos, o estancias, que le componen, y del numero de Yndios /foja 6r/ de todas clases que en cada vno de ellos exista=

Que se averiguen los Bienes o rentas de Comunidad que tienen los Yndios de cada repartimiento expecificandose con toda claridad, y distincion a cuyo fin los manifestaran los Curas, y Casiquez y esta razon se pondra al pie de la revicita de el que concluida en el todo de la Provincia se despacharan sus autos originales al Superior Govierno, acompanados del respectibo Ynforme Jurado dejandose testimonio autorisado de la revicita de cada repartimiento con su correspondiente Caxa de Comunidad, y de no haberla en el Archibo de la Provincia para el Govierno de los Correxidores que la sirvieren interin no se efectua nueba rumeracion= Que desde el Tercio en que se concluye la revicita en cada Repartimiento en los dos que comprehende el año de San Juan y Navidad, sin aguardar a su aprobación, y despacho de Retazas, se ha de hazer la cobranza de tributos segun el numero de Yndios que se hallaren exsistentes, bien sea resultando aumento, o diminucion, a la anterior, siendo obligado el Correxidor Revicitador a pasar el Documento comprobante de ello a la Real Caxa del Partido, para que puedan liquidar el cargo los ofiziales Reales, cuyo Podatorio debe igualmente haserlo por su parte a fin de que no se alegue en ello 
Decicion

Obedecimiento

Auto

Auto

Aceptacion y juramento ygnoransia que ocacione detrimento a la real Hazienda /foja 6v/ Que desde el instante que se reciba la provicion de Revicita se de subsesiba rrason al tribunal de Cuentas, y contaduria general de retazas del estado en que se hallare para que se este a la mira de su prompta conclucion= Don Juan Jossef de Leuro= En cuya conformidad, y en atencion a lo expuesto por el contador de Retazas, y pedido por los Senores Fiscal, y Fiscal Protector general doy la presente por la qual mando a Vos el Correxidor de la Provincia de Arica, que luego, y sin la menor demora que se os entregue, prosedan a haser revicita y numeracion de los Yndios que se contuvieren en los repartimientos, y Pueblos de buestra Jurisdicion con arreglo a los Capitulos de la Ynstruccion nuebamente establecida, y aprobada por este Superior Govierno aqui insertos concluiendole dentro del presisso termino de seis meses como se os ordena en el Capitulo Sexto de dicha Ynstruccion, y bajo del apersebimiento que contiene su tenor, y conclusas dichas Diligencias con las formalidades que en ella se advierten las remitireis con los autos anteriormente obrados, y buestro informe Jurada a mi Secretaria de Camara, serrado, y sellado para en su vista proveer lo combeniente. Lo que cumplireis, y executareis vajo la pena de quinientos pessos aplicados para la real Camara de su Magestad, y de la responsabilidad a los perjuicios que por buestra omicion se originaren a la real Hazienda, y demas ynteresados /foja 7r/ y se tomara razon de este Despacho en el Tribunal de Cuentas, y Contaduria de retasas de este Reino Fecho en los Reyes del Peru en treinta de Diziembre de mil setecientos setenta y dos años= Don Manuel de Amat= Por mandado de Su Exselencia el Marques de Salinas $=$ Vna rubrica $=$ Otra rrubrica $=$ Provicion de Revicita de la Provincia de Arica cometida al actual Correxidor de ella para que la execute como ba prevenido en conformidad del Decreto inserto $=$ Tomose razon en el Tribunal de Cuentas de este Reyno donde queda copia de Este Despacho. Lima ocho de Enero de mil setecientos setenta y tres anos= Juan Francisco Navarro= Tomose rrazon en la Contaduria General de retazas de este Reyno donde queda copia de este Despacho, Lima, y Enero ocho de setecientos setenta y tres años= Don Juan Jossef de Leuro= En el

Pueblo de Tacna Jurisdicion de la ciudad de Arica a quinze dias del mes de Julio de mil setecientos, y setenta y tres años. El General Don Demetrio Egan del Orden de Santiago Theniente Coronel de los Reales Exercitos Correxidor y Justicia mayor en ella por su Magestad: Haviendo visto la Provicion de las fojas antesedentes Despacha por el exselentizimo Señor Don Manuel de Amat, y Juniet del Orden de San Juan Virrey Governador, y Capitan General de Estos Reynos del /foja 7v/ Peru, y Chile en que se me confiere comicion para que haga revicita, y numeracion de Yndios de esta dicha Provincia, la que obedesco con mi mayor respeto, y a maior abundamiento la Juro por Dios Nuestro Señor, y la Cruz de mis pechos de usar bien, fielmente la dicha comicion, a todo mi leal saber, y entender, y de guardar cumplir y ejecutar lo que por ella se me manda arreglandome en todo a la instruccion que en ella se me da, y lo firme actuando con testigos a falta de Escribano Publico y real que sertifico no le hay en la Provincia Demetrio Egan= testigo Juan de Velasco, y Vrdanivia= testigo Rafael

Bamondes= En dicho Pueblo de Tacna en el zitado dia mes, y año haviendo obedecido la Provicion de Revicita que se me ha conferido por el Exselentissimo Señor Virrey de estos Reynos En su cumplimiento, y con arreglo al Capitulo primero de Ella debia Mandar, y mando que don Juan de Velasco, y Vrdanivia, por no hauer Escribano Publico ni Real con la comicion necesaria, pase a la real caja, y en ella site a los Señores ofiziales Reales el contenido de dicha Provicion, para que vno de dichos Señores asista como esta prevenido, y asimismo al Protector de Naturales nombrado por dicho Superior Govierno Don Juan Jossef Lopez de Santana sentando las diligencias a su continuacion: assi lo provei, mande y firme actuando con testigos a falta de Escrivano Publico y Real= Demetrio Egan = /foja 8r/testigo Juan de Velasco, y Vrdanibia= testigo Rafael Bamondes= En dicho dia mes y año, Yo el Comicionado nombrado Pase a la real Caxa que reside en este Pueblo de Tacna, y en ella site como se manda a los Señores Jueses ofiziales Reales para que vno de dichos Señores asista a la revicita, y numeracion de Yndios de esta Provincia, y respondieron que por hallarse embarasados en asumptos pertenencientes a sus empleos en dicha Real Caja no podian ninguno de ellos asistir, y que en virtud de la facultad que se les concede nombraban a don Juan Esteban Viscarra para que este en calidad de Defensor de la Real Hazienda asistiese a dicha Revicita quien aseptando, y Jurado el Cargo daria el lleno a su obligacion, y lo firmaron conmigo $=$ Fausto Calderon de la Barca $=$ Jossef Joaquin de Castro= Juan de Velasco, y Vrdanibia $=$

En atencion a aver respondido los señores ofiziales Reales que por hallarse embarasados en su ministerio, y atencion de las Reales Caxas de su Magestad, y no poder salir ninguno de ellos a dicha Revicita, y haber en su lugar nombrado para que en calidad de Defensor del real Haver concurra Don Juan Esteban Viscarra, Devia mandar, y mando que el suso dicho comparesca, a aceptar, y Jurar el cargo. Assi lo proveo mando y firmo Yo el Juez de Revicita actuando con testigos /foja 8v/ a falta de Escribano Publico y real= Demetrio Egan= testigos Juan de Velasco, y Urdanivia= testigo Rafael Bamondes= En el Pueblo de Tacna a veinte dias del mes de Julio de mil setecientos, y setenta y tres años ante mi el General Don Demetrio Egan 
del orden de Santiago Theniente Coronel de los exercitos Corregidor y Justicia Mayor de la Provincia de Arica y Juez revicitador de ella: Comparecio Don Juan Esteban Viscarra Defensor de Real Hacienda nombrado por los Señores Ofiziales Reales, quien enterado de dicho nombramiento lo asepto, y Juro por Dios Nuestro Señor, y a una Cruz de usar fiel, y legalmente de dicho ofizio, y a su leal saber, y entender, y lo firmo conmigo, y los testigos con quienes actuo a falta de Escribano Publico y Real Demetrio Egan= Juan Esteban de Viscarra= testigo Juan de Velasco y Vrdanibia= testigo Rafael Bamondes= En dicho Pueblo de Tacna, a veinte dias del mes de Julio de mil setecientos, y setenta y tres años. Yo el dicho comicionado Pase a la Cassa y morada del Señor Protector de Naturales Don Juan Jossef de Lopez de Santana quien hize saber el auto de zitacion, para que como tal Protector asista a la revicita, y numeracion de Yndios que se ba a haser, quien aviendolo oido, y entendido Dijo que esta prompto asistir a ella, y cumplir con la obligacion de su cargo, y a mayor abundamiento Jura por Dios Nuestro Señor, y a una Cruz de usar fiel, y legalmente de su empleo, y lo firmo, conmigo en el zitado dia mes y año= Juan Jossef Lo /foja 9r/ pez de Santana= Juan de Velasco, y Vrdanibia= En dicho Pueblo de Tacna a treinta del mes de Julio de mil setecientos, y setenta y tres años; Yo el dicho Juez de revicita para dar principio a ella debia mandar, y mando se libren los Titulos y nombramientos correspondientes de los ofiziales que deben asistir a ella para que aseptandolos, y Jurando el cargo se proseda a ella conforme se prebiene en las Ynstrucciones y Provicion real de Revisita lo que assi provei, mande y firme actuando con testigos a falta de Escribano Publico y Real= Demetrio Egan= testigo Juan de Velasco Y Vrdanivia testigo Rafel Bamondes= En el Pueblo de Tacna a treinta y tres años Don Demetrio Egan Del orden de Santiago Theniente Coronel de los Reales exercitos Corregidor y justica mayor de la ciudad de Arica y su Provincia Juez de Revicita, y numeracion de Yndios de la dicha Provincia por el real, y Superior Govierno de estos Reynos etc. Por quanto se hase preciso, y necesario el nombramiento de Alguacil para que asista a dicha revicita, y que en este concurran las Calidades necesarias; concurriendo estas en la Perzona de Don Bernardo Vilanoba en nombre de su Magestad (que Dios Guarde) y como tal Juez revicitador lo elijo; y nombro por tal Alguasil de Revicita, para que use del con todo lo del anexso, y consentimiento, y se le guardaran /foja 9v/ los fueros honores, y privilegios que le coresponden lo que le hara sauer Don Juan de Velasco, y Vrdanibia, y que comparesca ante mi a Jurar, y aceptar el cargo: Que es fecho en este dicho Pueblo en el sitado dia mes y año, y lo firme actuando con testigos a falta de Escribano Publico y real= Demetrio Egan= Testigo Juan de Velasco, y Vrdanivia= testigo Rafael Bamondes= En dicho Pueblo de Tacna dicho dia mes y año Yo el Comicionado en virtud del nombramiento antesedente, Pase a la Casa, y morada de Don Bernardo Vilanoba a quien se lo hise saber, y Dijo pasaria a otorgar la aceptacion, y Juramento lo que sertifico y

Aseptasion y firmo= Juan de Velasco, y Vrdanibia= En el Pueblo de Tacna a treinta dias del

Juramento mes de Julio de mil setecientos, y setenta y tres años ante mi el General Don Demetrio Egan del orden de Santiago Theniente Coronel de los reales Exercitos Correxidor y Justicia mayor de la dicha ciudad de Arica, y su Provincia Juez revicitador de los originarios de ella Pareio Don Bernardo de Vilanova Alguacil mayor nombrado para dicha revicita, y numeracion de Yndios y en su virtud asepto, y Juro el cargo por Dios Nuestro Señor y vna Señal de Cruz que hizo de usar fiel, y legalmente de dicho empleo, y lo firmo conmigo y los testigos con quienes actuo a falta de Escrivano Publico y Real $=$ Demetrio Egan $=$ Bernardo de Vilanoba $=$ testigo Juan de Velasco, y Vrdanibia $=$ testigo Rafael Bamondes=

Nombramiento de amanuense

\section{Don Demetrio Egan del Orden de Santiago Theniente Coronel de los Reales}

xercitos Corregidor y Justicia mayor de la ciudad de Arica y su Provincia/Foja 10r/Juez Revicitado de la Numeracion de Yndios de ella por el real, y Superior Govierno de Estos Reynos: Por quanto se hase presiso el nombramiento de Amanuense para que escriba dicha numeracion en virtud de la Provicion de Revicita, y de concurrir en la Perzona de Don Rafael Bamondes la avilidad Correspondiente le elijo, y nombro por tal Amanuense con el Salario de sua signacion señalado en dicha Provicion de Revicita, y mando comparesca ante mi para que aseptando, y Jurando el Cargo actue, y ejersa dicho empleo, y se le guarden los fueros honores, y privilegios que le corresponden que es fecho en este Pueblo de Tacna a treinta dias del mes de Julio de mil setecientos setenta y tres años, y lo firme actuando con testigos a falta de Escribano Publico y Real= Demetrio Egan= testigo Juan de Velasco y Vrdanivia $=$ Testigo Gregorio de Lavayen $=$ En dicho

Aseptacion y Pueblo de Tacna a treinta dias del mes de Julio de mil setecientos setenta y tres

Nombramiento años ante mi el General Don Demetrio Egan del Orden de Santiago Theniente Coronel de los Reales Exercitos Correxidor y justicia maior de la dicha ciudad de Arica y su Provincia Juez Revicitador de la numeracion de Yndios de ella Parecio Don Rafael Bamondes, y en virtud del nombramiento hecho en su perzona de Amanuense para dicha Revicita, y numeracion Dijo que aseptaba dicho cargo, y Juro por Dios Nuestro Señor, y una señal de Cruz de usar fiel, y legalmente del dicho cargo, y lo firmo conmigo, y los testigos con quienes actuo a falta de Escrivano Publico y Real= Demetrio Egan $=$ Rafael Bamondes $=$ testigo 
Nombramiento Juan de Velasco, y Vrdanibia= testigo Gregorio de Lavayen= En el Pueblo de

Ynterprete Tacna en cinco dias del mes de Agosto de mil setecientos setenta y tres años Don Demetrio Egan del Orden de Santiago Theniente Coronel de los Reales Exercitos Correxidor y Justicia Mayor /foja 10v/ de la Ciudad de Arica y su provincia Juez de Revicita, y Numeracion de yndios de la dicha Provincia por el real y Superior Govierno de estos Reynos etc . Por quanto se hase presiso, y necesario el nombramiento de Ynterprete que sepa las Lenguas de los Yndios para que les haga entender en su Ydioma como se actua la Revicita, y numeracion, y que arr[e]glado a los Capitulos de la Provicion de dicha Revicita se proceda en todo con aquel acuerdo devido; hallandose con las calidades necesarias Don Jossef Sinforiano Ximenes en nombre de Su Magestad (que Dios Guarde), y como tal Juez Revicitador elijo, y nombro por tal Ynterprete al dicho Don Jossef Sinforiano con el salario asignado a su empleo en las Ynstrucciones de dicha Revicita; y mando comparesca ante mi, para que aseptando, y Jurando el cargo actue y exersa dicho empleo, y se guarden los fueros honores, y privilegios que le corresponden. Que es fecho en dicho Pueblo dicho dia mes, y año: y lo firme actuando con testigos a falta de Escribano Publico y Real= Demetrio Egan= testigo Juan de Velasco, y Vrdanivia= Joaquin Gonzales Vigil= En dicho Pueblo de Tacna en dicho dia mes, y año ante mi el General Don Demetrio Egan del orden de Santiago Theniente Coronel de los Reales exercitos Corregidor, y Justicia mayor de la dicha ciudad, y su Provincia Juez Revicita[do]r de los originarios de ella. Parecio Don Jossef Sinforiano Ximenes, nombrado para dicha Revicita, y Numeracion de Yndios, y en su virtud asepto y Juro el Cargo por Dios Nuestro Señor, y vna Señal de Cruz que hiso de usar fiel, y legalmente de dicho Empleo, y lo firmo conmigo, y los testigos con quienes actuo a falta de Escribano Publico y real= Demetrio Egan= Jossef Sinforiano Ximenes $=$ testigo Juan de Velasco y Vrdanibia $=$ Testigo Joaquin Gonzales

Exorto Vigil = /foja 11r/ Don Demetrio Egan del orden de Santiago Theniente Coronel de los Reales Exercitos Corregidor y Justicia mayor de la Ciudad de Arica y su Provincia por Su Magestad Juez de Revicita y Numeracion de Yndios de ella por Comicion expecial del Real y Superior Govierno de estos Reynos. Al Señor Doctor don Diego de Zaconeta y Ramires cura y vicario Juez Ecleciastico de la Doctrina de San Martin de Codpa Hago saber que en este dicho Pueblo como cabeza Principal de todo este repartimiento ha de comensar la revicita, y numeracion de Yndios, y para que se haga con la justificacion y formalidad que combiene atento a que por la Provicion de Revicita se me ordena, y manda haga pareser los Libros de Baptismos Entierros, y Casamientos que hay en esta Santa Yglecia para que consten las Edades de los que exsisten. Por tanto exorto, y requiero a vuestramerced de parte de Su Magestad (que Dios Guarde) y de la mia le ruego, y encargo que siendole notoria esta mi Carta exortatoria en su conformidad se sirba de exsivir, y entregar al presente Alguacil maior de Revicita todos los Libros de Baptismos Entierros y Padrones Generales de Confeciones de esta Santa Yglecia de todos los Yndios de todos estados assi originarios como Forasteros para que conforme dellos se baian numerando, y empadronando con toda claridad, y que no se defraudado $\mathrm{Su}$ Magestad en sus reales Tributos que acabada la revicita se debolveran originales como los entregare; que en hacerlo assi cumplira con lo que debe en servicio de Su Magestad, y Yo quedare al tanto para cada que las suyas vea Justicia mediante. Que es fecho en dicho Pueblo de Codpa a nuebe de octubre de mil setecientos setenta y tres años, y lo firme actuando con testigos /foja 11v/ a falta de Escribano Publico y Real= demetrio Egan= testigo Juan de

Notificacion Velasco y Vrdanibia= Testigo Joaquin Gonzales Vigil= En el Pueblo y Doctrina de San Martin de Codpa Jurisdicion de San Marcos de Arica en dies dias del mes de octubre de setecientos setenta y tres años Yo el Alguacil mayor de Revissita Don Bernardo de Vilanova. En virtud de la Comission que se me confiere passe a la Cassa de morada del Señor Doctor Don Diego de Zaconeta Cura, y Vicario de ella, a quien le hise saber el contenido de este exorto, y en su cumplimiento entrego los Padrones de confeciones de los años de setenta y dos, y setenta y tres y los Libros Siguientes= Primeramente vno de Baptismos, Cassamientos, y Entierros que empieza desde el año de mill de seiscientos quarenta, y nuebe hasta el año de seisicientos ochenta y cinco= Yttem otro dicho que comienza desde el año de setecientos setenta y cinco hasta el año de setecientos dies y seis $=$ Yttem otro dicho de Baptismos que comienza en el año de setecientos quarenta hasta el de setecientos setenta y tres $=$ Ytten otro dicho de Baptismos, y Entierros que comiensa el año de setecientos cinquenta, y quatro hasta el de setesientos setenta y tres $=$ Ytten otro dicho de Bapttismos, y entierros que comiensa el año de setecientos treinta y siete /foja 12r/ hasta el de setesientos cinquenta y quatro $=$ Yttem otro dicho de Casamientos que empieza el año de setesientos treinta y siete hasta el de setecientos cinquenta y quatro= Yttem otro dicho de Baptismos que comienza el año de setecientos sesenta y tres asta el de setecientos el de setenta y tres= Ytten otro dicho de Entierros que empieza el año de setesientos cinquenta y nuebe hasta el de setesientos setenta y tres= Ytten otro dicho que empieza el año de setecientos setenta y tres Los que passe a mi Poder para entregarlos al Señor Juez de revicita, y para que conste lo pongo por dilixencia y firmo con testigos a falta de Escribano de 
Edicto revicita $=$ Bernardo de Vilanova= testigo Joaquin Gonzales Vigil= Don Demetrio Egan del orden de Santiago Theniente Coronel de los Reales Exercitos Correxidor y Justicia maior de la Ciudad de Arica y su Provincia, y Juez Revicitador por expecial Comicion del real y Superior Govierno de estos Reynos. Hago saber al Casique y Gobernador Alcaldes y Principales de este Repartimiento del Pueblo de Codpa, y sus Altos y a todos los demas Yndios originarios de el como me hallo con expecial comicion del Exselentissimo Señor Virrey de estos reynos para que haga revicita y numeracion de yndios del distrito de este mi Correximiento a cuyo fin he venido a este dicho Pueblo; y para dar principio a la dicha Revicita en conformidad de lo que se me previene por Provicion despachada por su Exselencia combiene que ante todas cosas se junte el Comun y Principales de este repar /foja 12v/ timiento de Codpa en la Plaza Publica de este Pueblo, y por el Ynterprete nombrado para esta revicita se les de a entender en su Ydioma natural que tengo señalado el dia de mañana en que se ha de comensar a haser la dicha revicita y Nuemeracion de Yndios por los Libros de Baptismos Entierros cazamientos, y Padrones Generales de Confeciones, y con arreglo a la ultima revicita y que no oculten ningunos Yndios en la presente y que a los Yndios ausentes los declaren el Casique, y Principales con toda brevedad sin que en ninguna manera los oculten aunque se esten sirviendo de ellos so pena de pribacion perpetua de sus ofizios, y de otras penas que se les impondran, y con apercebimiento que se les hase a todos los Yndios Principales de este repartimiento que hagan la dicha manifestacion assi de Yndios ausentes quienes son, y quantos, y en que partes, y lugares assisten, y que hijos tienen, y si el Casique o Principales por sus particulares intereses tienen ocultos algunos de los dichos Yndios lo digan, y declaren ante mi dicho Juez de revicita sin tener ningun temor al dicho Casique, para lo qual los admito debajo del amparo real, y que seran castigados los culpados y premiados a los que hicieren las dichas manifestaciones azi de Yndios Tributarios como Muchachos, y que seran reservados de tributos, mitas y trabajo personal, y se les nombrara por Casiquez de los Yndios que descubrieren, y a los que no hiciesen las dichas manifestaciones ocultando la verdad maliciosamente les seran dados Doscientos azotes trasquilados y desterrados al socabon de Guancabelica por un año todo lo qual se les de a entender al comun de los Yndios Casique, y Principales por lo mucho que importa al servicio de Su Magestad e interenados [sic] en este dicho repartimiento, y para que llegue a noticia de todos mando se publique por Bando en la Plaza Publica de este Pueblo a son de Caxa, y voz de Pregonero, y de haberse assi Publicado se pondra por testimonio. Assi lo provey mande y firme en este dicho Pueblo, en onse dias del mes de octubre de mil setecientos setenta y tres años actuando con testigos a falta de Escribano Publico y real= Demetrio Egan $=$ testigo Juan de Velasco y Vrdanivia= testigo Joaquin

Notificasion Gonzalez Vigil= En el Pueblo de Codpa en dies de octubre de mil setecientos setenta y tres años Yo el Alguacil maior de Revicita mande publicar el dicho antesedente en la Plaza publica de dicho Pueblo en concurso de mucha Gente, el Governador Alcaldes y Principales, y lo hise explicar con el Ynterprete de la revicita en su idioma natural la que pongo por diligencia y lo firmo Bernardo [Manuscrito roto] /foja 13r/ Revicita y Padron que hago Yo el General Don Demetrio Egan de la orden de Santiago Theniente Coronel de los Reales Exercitos de Su Magestad (que Dios Guarde) Correxidor y Justicia mayor de la Ciudad de Arica y su provincia Juez revicitado por expecial comicion del real y Superior Govierno de Estos Reynos de los Yndios originarios, y avecindados en este Repartimiento Doctrina de Codpa, y sus Anexos de la real Corona y Patrimonio de Su Magestad, la qual se ha echo con vista de la revicita fecha por Don Joachin Xavier de Cardenas, y reconocimiento de los Libros de Baptismos, Casamientos Entierros, y Padrones de Confeciones que a este efecto entrego el Doctor Don Diego Saconeta, y Ramires, cura propio Vicario Juez Ecleciastico de esta Doctrina, y los Padrones de los Tributarios, que exibe el Casique Don Diego Phelipe Cañipa oi dies de Octubre de mil setecientos setenta y tres años a que Asistieron los Señores Don Juan Esteban Viscarra defensor de real Hazienda dicho Señor Cura con los demas Ministros actuarios nombrados para ella, la que se dio principio en la forma, y manera siguiente,

Pueblo de San Martín de Codpa, y aillo Collana

\section{Casa del Casique}

Don Diego Phelipe Cañipa Casique y Governador Principal por Titulo del Superior Govierno de edad de quarenta y ocho años casado con Doña Antonia Nuñez de quarenta y tres años tiene por hijos

Eugenio Primogenito de veinte y tres años

Francisco Xavier de seis años

Maria de veinte años casada con Andres Blanco Español- 


\section{Originarios Casados con tierras}

Principal Juan Buitron de treinta y un años casado con Josepha Medina de treinta años

Tadeo de quatro años

Acencia de dies años

Maria de seis años

Juan Saravia de treinta y seis años casado con Marti

/foja13v/ na Samorano de treinta y sinco años tiene por hijos

Agustin de siete años

Agustin Aranibar de treinta y dos años casado con Ylaria

Cruz de quarenta años tiene por hijos de otro matrimonio

Juan de doze años $=$ Y del presente a

Ysidro de sinco años

Clara de siete años

02 Theresa de dos años

Antonio Saravia de veinte y tres años casado con Josepha Yante de

veinte y dos años tiene por hija

Josepha de tres años

Bernardo Mollo de veinte y sinco años casado con Francisca

Flores de treinta años

Domingo Alabe de quarenta y seis años casado con Gregoria

Canqui de veinte y nuebe años tiene por hijos

Bernardo de nuebe años

Lucas de quatro años

Ygnacio de vn años

Diego Monte de quarenta y dos años casado con Pheliciana

Umajaya de quarenta años= tiene por hijo

Pablo de nuebe años

Diego Blas de treinta y vn años casado con Ana Romero

de treinta y sinco años

Dionicio Quinquincha de veinte años casado con Dionicia

Medina de dies y ocho años

Juan Alabe de quarenta años casado con Lorenza Laime

de treinta y sinco años tiene por hijos

Juan de la Cruz Atanacio de siete años

Pedro Nolasco de quatro años

Bernardo de dos años

Ciguel Guerra de treinta y ocho años casado con Pheliciana

Pheliciana de siete años

Alejandro Mollo de treinta y nuebe años casado con

Eugenia Conde de treinta y seis años tiene por hijos

Vizente de nuebe

Francisco de sinco años

Geronimo Quenaya de veinte y dos años casado con Pheli [sic]

[probablemente falta una foja]

/foja 14r/ Solteros Fortasteros sin tierras

Mauricio Alani de la Paz al pareser de quarenta y quatro años

Diego Mata Camaya de carangas al pareser de veinte años

Torivio Solano de Dies y ocho años

\section{$\underline{\text { Reservados }}$}

Francisco Conde de sinquenta y quatro años casado con 
60

Juana Roque de sesenta años

Santos Quenaya de setenta años casado con Cecilia Veles de sinquenta años tiene por hijo

Lucas de dies años

Santos Vilca de sinquenta y seis años

Jossef Ramos de sesenta años casado con Maria Bartola $\quad 60$

de sinquenta y seis años

Matheo condori de sesenta y cinco años

\section{$\underline{\text { Viudas }}=$}

Casilda Vmajaya de veinte y ocho años tiene por hijos

Justo Flores de ocho años

Maria de dose años

Maria Canqui de quarenta y cinco años por hijos

Feliciano Medina de dies y seis años

Blas de dose años

Nicolas de sinco años

Domingo de siete años

Bernarda Medina de dies años

Sebastiana Colquema de quarenta y cinco años tiene por hija

Maria medina de dies y ocho años

Theresa Garcia de quarenta años tiene por hijos

Domingo Quispe de onse años

Mateo Quispe de quatro años

[No legible]

/Foja 14 v/

Bernarda de dies y ocho años

Manuela de dies y seis años

Ynes Quispe de dos años

Thomasa Romero de treinta y sinco años tiene por hijos

Matias de tres años

Micaela de un año

Petrona Ramires de treinta y cinco años tiene por hijo

Fernando Ramires de dies y seis años

Jossefa Rodríguez de veinte años

juana Peres de setenta años

Flora Guaiba de sesenta años tiene por hija -a-

Faustina Montealegre de veinte años

Luciana Catari de quarenta años tiene por hija

Tiburcia de seis años

Juana Alanoca de ochenta años

Bernarda Vilca de sinquenta años

Marta Ximenes de sinquenta y cinco años

Gregoria Gomes de setenta años

Juana Mamani de sinquenta y cinco años

Tomasa Alabe de treinta años tiene por hijos

Gaspar de seis meses

Agustina de tres años

\section{Huérfanos}

Pablo Thorres de sinco años

Andres Aranibar de dose años

Juan de Dios de siete años

Jossef Umajaya de siete años

Francisco Vilalba de siete años

Jossef Jauriundo de trese años

Fransisco Veles de sinco años

Lasaro Ramos de dos años y seis meses

Fernando Blas de cuatro años 
Ubaldo Blas de seis años

\section{Huérfanos [sic]}

Pheliciana Guenaya de dies y ocho años

Luciana Veles de dies y seis años

Maria Blasa de dies y ocho años

Maria Aranibvar de dies y siete años

Paula Blasa de dose años

Marcela Mamani de nueve años

Petrona Vilialva de siete años

Gernonima Quenaya de veinte y [Ilegible: pliegue de la foja]

\section{/Foja 15r/}

Faviana Xauriundo de dies y seis años

Foribia Xauriundo de catorse años

Manuela Quenaya de dies y seis años

Ygnacia Peres de seis años

Theresa de seis años

Sebastiana de ocho años

Petrona de dies años

Vicencia de seis años

\section{Cholos casados con tierras}

Martín Garcia de treinta y seis años casado con Gertrudis

Acencio de seis años

Thadeo de tres años

\section{$\underline{\text { Cholos solteros sin tierras }}$}

Martín Velasco de dies y ocho años

Fernando Albornos de dies y ocho años

Eugenio Medina de dies y ocho años

\section{Cholas viudas}

Ysabel Gutierres de quarenta años tiene por hijos

Marcela Saravia de veinte años

Josepha de dies y ocho años

Maria de dies y seis

Gertrudis de doze años

Marta Flora de treinta y sinco años tiene por hijos a

Francisco Xavier de dose años

Gregoria Flora de seis años

Tomasa Vargas de quarenta años tiene por hijos

Francisco de dies años

Gregorio de ocho años

Pablo de tres años

Antonia de siete años

Ysidora de sinco años

Manuela Cañipa de quarenta y dos años

Pheliciana Saravia de treinta años= tiene por hijos

Pedro de un mes

Bernardina de seis años 
25

11

06

03

30

\section{/Foja 15v/}

Juana Alave de veinte y sinco años tiene por hijos

Acencia de onse años

Manuela de seis años

Nicolasa de tres años Gemelas

Petrona de tres años

Maria Canqui de treinta años tiene por hijos

Marcelo de ochos años

Bernardo de seis años

Micaela Flora de treinta y sinco años tiene por hijos

Simon Torres de catorce años

Jerónimo Lobera de un año

Tomasa Flora de dies y seis años

Ysidora de dose años

Antonia de dies años

\section{Cholas solteras}

Marcela Garcia de dies y ocho años

Pheliciana Garcia de veinte años

Petrona Garcia de dies y seis años

\section{Zambaigos casados con tierras}

Jossef Garcia de treinta y ocho años casado con Esperanza 38

Conde de treinta y sinco años tiene por hijos

Pheliciano de doze años

Manuela de catorce años

Juana de Dios de siete meses

Fransisco Montealegre de quarenta y sinco años casado

Juana Mamani originaria de treinta y seis años tiene por hijos

Agustin de dies años

Maria de doze años

Micaela de ocho años

Faustina de actorze años

Lorenza de seis años

Josepha de tres años

\section{$\underline{\text { Zambaigos solteros sin tierras }}$}

Pablo Laraso de veinte años

Lorenzo Mangas de quarenta años

Diego Zegarra de treinta años

Phelipe Lazaro de [Ilegible: pliegue de la foja]

/Foja 16r/

\section{Aillo de Capanique en Codpa= $\underline{\text { Originarios casados con tierras }}$}

Matheo Blas (Principal) de treinta y siete años casado

con Bartola Ramires de treinta y ocho años tiene por hijos

Fernando de nuebe años

Melchora de doze años

Velasco de treinta y tres años tiene por hijos

Zelestino de nuebe años

Manuel de siete años

Basilio de tres años

Maria de sinco años

Victorio Apas de treinta y ocho años casado con Maria Garcia 
50

12

06

de sinquenta años tiene por hijos

Pedro de nuebe años

Margarita de doze años

Barbara de seis años

Maria de tres años

Bernardo Yante de quarenta y sinco años casado con Evarista

Gallegos de quarenta y sinco años tiene por hijos

Pheliciano de dies y seis años

Luciana de doze años

Luciana de dies años

Andrea de seis años

Vizente Ocsa de quarenta años casado con Luciana Canqui

de treinta años tiene por hijos

Manuel de tres años

Lorenzo de un año y seis meses

Pheliciana de siete años

Acencia de sinco años

Basilio Quispe de quarenta y un años casado con

Pheliciana Zarate de treinta y sinco años tiene por hijos

Maria de sinco años

Victorio Alabe de quarenta y seis años casado con

Marta Buitron de quarenta y tres años tiene por hija

Fransisca de catorze años

Esteban Alabe de veinte y quatro años casado con

Josepha Castro de veinte años

Eusebio Garcia de quarenta y vn años casado

[foja16v]

Rosa Romero Albano de treinta y ochos años tiene por hijos

Julian de nuebe años

Ermenegildo de quatro años

Esteban Umajaya de treinta y ocho años casado con Juana 38

Yañes de treinta años tiene por hijos

Casimiro de nuebe años

Ysabel de siete años

Francisco Cayetano Blas de veinte y ocho años casado con

Marina Molle de veinte años tiene por hijos

Eugenia de tres años

Fransisco Caqueo de treinta y dos años casado con

Micaela Moscoso de treinta y sinco años tiene por hijos

Manuel de nuebe años

Pheliciana de siete años

Maria de las Mercedes de sinco años

Fransisco Caqueo de treinta y vn años casado con Maria

Ramos de veinte y ocho años

Gregorio Velasco de quarenta y sinco años casado con

Magdalena Vmajaya de quarenta y sinco años tiene por hijos

Pedro de quinse años

Eugenio de trese años

Ygnacio Azango de treinta años casado con Maria

Casimiro de quatro años

Agustin de dos años

Molle de quarenta y sinco años tiene por hijos

Manuel de quinse años

Pablo de dose años

Juan de Dios Yante de treinta y siete años casado con 37

Fransisca Caqueo de quarenta años tiene por hijos

Eugenio de ocho años $=\mathrm{Y}$ ella de otro matrimonio a 
09

Martina de nuebe años

Joseph Mamani de treinta años casado con Tomasa

Ocsa de treinta y sinco años

\section{[foja 17r]}

Jossef Vmajaya de veinte y seis años casado con

Margarita Canqui de treinta años $=$ tiene por hijos

Andres de un año y seis meses

Lorenzo Romero de quarenta y vn años casado con

Lorenza Calle de treinta y siete años tiene por hijos

Manuel de ocho años

Lorenzo de dos años

Agustina de sinco años

Miguel Asango de quarenta y siete años casado con

Sebastiana Real de quarenta y sinco años tiene por hijos

Acencio de siete año

Narciso Asango de quarenta años casado

Manuel de vn año

Melchora de trese años

Petrona de quatro años

Pascual Mauiricio de veinte y tres años casado con

Tomasa Medina de veinte y quatro años

Ramon Asango de treinta y vn años casado con

Maria Garcia de treinta años tiene por hijos

Cayetano de seis años

Tadea de quatro años

Rafael Buitron de veinte años casado con

Antonia Vasquez de veinte años tiene por hijos

Brigida de vn años

Santos Veles de quarenta y un años casado con

Juana Guenaya de quarenta años tiene por hijos

Bernarda de dies años

Silvestre Yante de treinta y nuebe años casado

Martina Garcia de treinta y seis años $=$ tiene por hijos

Matias de dies y seis años

Agustin de dose años

12

Fernando de dies años

10

Fransisco de ocho años

Esperansa de seis años

Salvador Buitron de treinta y seis años casado con

Teresa Valdes de quarenta y sinco años tiene por hijos

Lucas de siete años

Micaela de veinte y quatro años

[Foja 17v]

Fransisco Ancani de veinte y seis años casado

con Simona Samorano de veinte y quatro años tiene por hijo

Pedro de tres meses

Miguel Carvajal de treinta años casado con $\quad 30$

Eugenia Peres de treinta y sinco años

Miguel Copa de veinte y vn años casado con 21

Thomasa Buitron de dies y ocho años

$\begin{array}{ll}\text { Diego Chola de quarenta años casado con } & 40\end{array}$

5 Gertrudis Vmajaya

Jossef Vilca de veinte y quatro años casado con $\quad 24$

Manuela Asango de veinte años tiene por hija 


\section{Forasteros casados con originarias con tierras}

Francisco Vmajaya de Miñimiñi al pareser de veinte y ocho años casado con Josepha Caqui de quarenta años tiene por hijos de otro matrimonio a Manuel de siete años

Gregoria de dies y ocho años

Ysidora de onse años

Jerónimo Choque Chambi de Carangas al pareser de treinta y seis años casado con Thomasa Asango de quarenta años= tiene por hijos Maria de dies y seis años

Juana de nuebe años

Marzela de seis años

Estefania de quatro años

Melchora de dos años

Sebastián Mamani de Carangas al pareser de treinta años

años casado con Micaela Caqui de treinta años tiene por hijos

Antonio de ocho años

Xavier de siete años

Maria de sinco años

Juan Barreda de veinte y quatro años casado con

Ermenegilda Garcia Española

[Manuscrito ilegible]

[Foja 18r]

\section{$\underline{\text { Forasteros casados con Forasteras sin tierras }}$}

Fransisco Lopez de Carangas al pareser de dies y ocho años

\section{$\underline{\text { Solteros originarios con tierras }}$}

Pedro Yante de dies y ocho años

Marcos Alabe de dies y nuebe

Fransisco Lobera de dies y ocho años

\section{$\underline{\text { Reservados }}$}

Juan Azango de sinquenta y tres años casado con

Ana Colque de sinquenta y seis años

Agustin Quea de sinquenta y sinco años

Diego Lopez de setenta años

Diego Apasa de sinquenta y tres años casado con $\quad 53$

Petrona Puma de sesenta y sinco años

Eusevio Gusman de sesenta y seis años casado con

66

Maria de la Cruz de quarenta y tres años

\section{Viudas}

Gregoria de veinte años tiene por hijo

Fransisco de un mes

Fransisca Gallegos de quarenta y vn años tiene por hijo

Fransisco de seis meses

Melchora Yachura de sesenta años 
50

40

07

Juliana Blas de sinquenta años tiene por hijo

Juan Lobera de dies años

Fransisca Perea de quarenta años tiene por hijos

Juan Blas de nuebe años

Sebastiana de siete años

Maria Choque de treinta años tiene por hijos

Miguel Vilca de dies años

Mariano de sinco años

Manuela de trese años

\section{[Foja 18v]}

Angelina Yante de quarenta y sinco años

Phelipa Yante de veinte años tiene por hijo

Valentin de dos años

Esperanza Lasaro de sinquenta años tiene por hijo

Diego Ramos de quinse años sinco meses

Bernabela de dies y siete años

Tadea de catorze años

Juana Blas de quarenta y ocho años tiene por hijos

Gregoria de catorze años

Gregoria de dies y ocho años

Martina de dose años

Sebastiana Morales de treinta años tiene por hijo

Clemente de vn año

Faustina Cruz de quarenta años $=$ tiene por hijos

Enrique de doze años

Maria Garcia de sesenta años

Juana Ocsa de treinta años tiene por hijos

Ana de sinco años

Barbara de vn año

Ana Catamaya de sesenta años

Marcela Pacheco de quarenta años tiene por hijos

Acencio de dies años

Carlos de dos años

Paula de ocho años

Maria Guanca de quarenta años tiene por hijos

Nicolas de siete años

Juan de dos años

Estefania de nuebe años

Thomasa Medina de sinquenta y sinco años

Rosa Gusman de sinquenta años tiene por hija

Paula Medina de catorze años

Rosa Bargas de sinquenta y sincoa ños tiene por hija

Paula Gutierres de dies y seis años

Acencia Mamani de treina y sinco años tiene por hija

Rosalia Fernandez de doze años

Pascuala Martina de quarenta años

Maria Margarita de sinquenta años

Maria Alabe de quarenta y ocho años tiene por hijo

Agustin de ocho años

Luciana Garcia de sinquenta años tiene por hija

Vrsula de ocho años

[Foja 19r]

Maria Romero de veinte y ocho años tiene por hija

Narsisa de quatro años

Maria Mamani de quarenta y sinco años tiene por hijo

Lorenzo de dose años

Rosa Asango de sinquenta años

Marcela asango de quarenta y ocho años

Ana Apas de quarenta y seis años tiene por hijas

Evarista de dies años

Luciana de ocho años 
Sebastiana Gusman de treinta y sinco años

Eugenia Zamorano de sinquenta años

Gertrudis Monte de quarenta y sinco años

Petrona Buitron de quarenta años tiene por hijos

Antonio de vn año

Ysabel de siete años

Juana Quispe de quarenta y sinco años tiene por hijos

Thomas Choque de onse años

Agustin Choque de nuebe años

Feliciana Choque Real de quarenta años tiene por hija

Melchora Real de quinse años

Fransisca Catari de quarenta años tiene por hijo

Rafael de dies años

Sebastiana Dias de sinquenta años

Petrona Garcia de quarenta años tiene por hijos

Fransisca Apasa de ocho años

Tibursio Apasa de sinco años

Apasa de tres años

Marcela Velasco de treinta y sinco años tiene por hijos

Santos Calle de sinco años

Nicolas de tres años

Anastacia Thenal de sesenta años

Marcela Cañipa de setenta años

Susana Romero de sesenta años tiene por hijos

Luciana Monte de dies y seis años

Dionicio Caqueo de doze años

Rosa Monte de veinte años tiene por hijos

Maria de tres meses

Maria Monica de sesenta años

Maria Guerra de sinquenta y sinco años

Maria Marca de sinquenta años

Maria Cruz de setenta años

[Foja 19v]

\section{$\underline{\text { Solteras }}$}

Margarita de dies y ocho años tiene por hijos

Gaspar de vn año

Rosa Buitron de veinte años tiene por hijo

Matias de dos meses

$\underline{\text { Huerfanos }}$

Antonio Mamani de trese años

Basilio Apasa de siete años

Pheliciana Carbajal de dose años

Phelipe Cruz de dies años

Esteban Asango de quatro años

Pedro Asango de dies y seis años seis meses

Xavier Valdes de dies y siete años

$\underline{\text { Huerfanas }}$

Pasquala Carbajal de trese años

Fransisca Morales de doze años

Rosalia Morales Mauria de trese años

Maria Garcia de quinse años

Toribia Yante de doze años

Ysidora Buitron de quinse años 


\section{Cholos casados con tierras}

Pablo Peres de veinte y ocho años casado con

Maria Choque de veinte y sinco años

\section{Cholos solteros con tierras}

Joseph Miranda de veinte años

\section{Zambaigos casados con tierras}

Carlos Sandobal de Chuquisaca al pareser de veinte y sinco años casado con Pheliciana Vmajaya de treinta años tiene por hijos Petrona de siete años

Barbara de vn año= La muger de otro matrimonio

Andres Copa de dies años

\section{Originarios del Pueblo de Pachica con tierras}

Esteban Sansola (Principal) de quarenta y siete años casado

con Pasquala Abario de quarenta y sinco años

Alejo Cailaco de quarenta y un años casado

con Fransisca Aguilar de quarenta años = tiene por hijos

Fernando de siete años

[Foja 20r]

Monica de nuebe años

Agustin Vmajaia de quarenta y vn años casado con

Bartola Mamani de sinquenta y tres años tiene por hijos

Thomasa de dies y ocho años

Antonio Albarado de quarenta y vn años casado con

Josepha Maria de quarenta y tres años tiene por hijos

Andres de trese años

Pasqual de onse años

Antonio Choque de veinte y nuebe años casado con $\quad 29$

Ysabel Aguilar de veinte y ocho años

Bernardo Cailaco de treinta y vn años casado

con Ana Quenaya de veinte y ocho años tiene por hijo

Ygnacio de sinco años

Carlos Choque de veinte y dos años casado con $\quad 22$

Evgenia Mamani de dies y siete años

Diego Cailaco de quarenta y siete años casado con $\quad 47$

Ana Viraca de quarenta y sinco años

Esteban Ajata de treinta y vn años casado con

Cruza Cailaco de veinte y ocho años = tiene por hijos

Domingo de dies años

Casilda de dies [años] y ocho meses

Fransisco Lasaro de quarenta y sinco años casado con 45

Petrona Ramires de quarenta y tres años

Fransisco Aguilar de treinta años casado con

Anastasia Yañes de treinta años tiene por hijos

Manuel de siete años

Enrrico de tres años

Vizente Cailaco de veinte y seis años casado

con Lorenza Tumbe de veinte y quatro años

Fransisco Perea de quarenta y seis años casado con

Juana Velasco de quarenta y seis años

Gregorio Lopez de veinte y seis años casado con

Thomasa Aguilar de veinte y sinco años tiene por hijos

Ylario Limachi de veinte y siete años casado 
Ygnacio Veles de veinte años casado con Maria

Maria Mamani de veinte y dos años

Jossef Guarachi de veinte y quatro años casado con

Ana Asango de veinte y sinco años

\section{[Foja 20v]}

Joseph Condori de veinte y seis años casado con

lucia Lopez de veinte y seis años tiene por hijos

Martin de sinco años

Maria de dos años

Justo Choque de veinte y nuebe años casado con

Maria Vmajaia de veinte y ocho años

Jossef Ramires de veinte y siete años casado con

Maria Lima de veinte y ocho años

Lasaro Mamani de treinta años casado con

Fransisca Flora de treinta y vn años

Mateo Gracia de veinte y dos años casado con

flora Mamani de veinte años

Mateo Gonzales de quarenta y vn años casado con

Maria Lopez de treinta años tiene por hijo

Esteban de vn año

Miguel Vilca de treinta y tres años casado con

Tomasa Quispe de treinta y sinco años tiene por hijos

Juan de dies y ocho meses

Lorenza de siete años

Simon Mamani de quarenta y ocho años casado con

Pasquala Aguilar de quarenta años tiene por hijos

Luis de catorze años

Gregoria de dies y seis

Josepha de tres años

Santos Apas de veinte y dos años casado con

Maria Quenaya de veinte años tiene por hijo

Victorio de tres años

Blas Fernandes de quarenta y seis años casado con

Juana Santos de treinta y sinco años tiene por hijos

Vrsula de quinse años

Ana de vn mes

Ambrosio Carbajal de veinte y quatro años casado con

Petrona Visa de quarenta años tiene por hijos

Bartola de dies años

Romualda de tres años

Gregorio Choque de treinta y vn años casado con

Lorenza Cailaco de treinta y sinco años tiene por hijos

Lorenzo de tres meses

Cruz Ajata de treinta y seis años casado con

Tomasa Challapa de quarenta años tiene por hijos

Pasqual de nube años

[Foja 21r]

Ana de siete años

Juan Choque de veinte y seis años casado con

Josepha Gonzales de veinte años

Blas Velasco de veinte y seis años casado con

Lorenza Ramos de veinte y sinco años

Marcos Quispe de veinte y vn años casado con

Josepha Caqueo de veinte años tiene por hija

Rafaela de vn mes

Tiburcio Limachi de dies y nuebe años casado con

Tomasa Gusman de veinte años

Acencio Mamani de quarenta y vn años casado con

Ygnacia Mamani de veinte y sinco años

Yldefonso Bernal de veinte y vn años casado con 
30

00,4

14

Acenia Aguilar de treinta años tiene por hijos

Bernardina de quatro meses $=\mathrm{y}$ la muger a.....

Rosa Cailaco de catorze años

Fransisca Cailaco de doze años

Martin Mamani de treinta y vn años casado con

Maria Mauricia de treinta años tiene por hijos

Bartolo de ocho años

Cruz Mamani de veinte y sinco años casado con

Catalina Colque de veinte y quatro años tiene por hijos

Manuela de tres años

Fransisco Aguilar de treinta años casado con

Acencia Cailaco de veinte y dos

Estebanm Velasco de treinta años con

Cruza Cailaco de veinte y ocho años tiene por hijos

Domingo de dies años

Casilda de vn año y seis meses

Forasteros casados con originarias con tierras

Antonio Tumbe de Carangas al pareser de treinta y seis años casado con Pheliciana Caqueo de treinta y vn años tiene por hija Fransisca de siete años

Pedro Mollo de Carangas al pareser de quarenta y

[Foja 21v] siete años casado con Maria de quarenta años

Rafael de dies años

Fransisca de quinze años

Narsiso Ramos de Carangas al pareser de quarenta años

casado con Martina Maria de treinta y ocho años tiene por hijos

Agustin de quinse años

Luis Ramos de siete años

Ana de dies y siete años

Marta de vn año

Ylaria de ocho años

Agustin Quispe de Carangas al pareser de quarenta y vn años

casado con Nicolasa de quarenta años tiene por hijos

Marcos de nuebe años

Antonio Blas de tres años

Josepha de siete años

Maria de vn mes

\section{$\underline{\text { Forasteros casado con Forasteras sin tierras }}$}

Gaspar Vilcarani de Carangas al pareser de treinta y seis años casado con Maria Rosa de treinta años de la misma Provincia tiene por hijo

Marcos de quatro años

\section{Provincia}

\section{Viudos forasteros con tierras}

Fransisco Cruz de Tarapaca al pareser de treinta años $\quad 30$

Juan de tres años 


\section{$\underline{\text { Solteros originarios con tierras }}$}

$\begin{array}{ll}\text { Simon Mamani Mollo de veinte y quatro años } & 24\end{array}$

Ysidro Asango de veinte años $\quad 20$

Benito Guarachi de dies y nuebe años $\quad 19$

Ygnacio Vmajaya de dies y nuebe años $\quad 19$

Gregorio Mamani de dies y ocho años 18

[Foja 22r]

Matheo Yante de treinta y sinco años $\quad 35$

Nicolas Caseres de dies y nuebe años $\quad 19$

$\begin{array}{ll}\text { Luis Mamani de dies y ocho años } & 18\end{array}$

$\begin{array}{ll}\text { Fransisco Velasco de dies y ocho años } & 18\end{array}$

$\begin{array}{ll}\text { Thomas Mollo de dies y ocho años } & 18\end{array}$

\section{$\underline{\text { Reservados }}$}

$\begin{array}{ll}\text { Cristobal Mamani de sinquenta y ocho años } & 58\end{array}$

Domingo Gonzales de treinta años Demente $\quad 30$

$\begin{array}{ll}\text { Bernardo Carbajal de sesenta años casado con } & 60\end{array}$

Maria Petrona de sinquenta años tiene por hijo

Manuela de dies y ocho años

Diego Choque de sinquenta y sinco años casado con

Josepha Cailaco de sinquenta años

Sebastian Choque de sinquenta y siete años casado

con Lupisa Mollo de sinquenta años tiene ella por hijos de otro

Matrimonio a

Andres Aguilar de sinco años

Miguel Lasaro de sinquenta y sinco años

$\underline{\text { Viudas }}$

Magdalena Alaba de sinquenta años tiene por hijo

Ambrosio de seis años

Thomasa Gonzales de sinquenta y sinco años

Fransisca Caseres de treinta y sinco años tiene por hijos

Antonio de siete años

Maria Choque de quarenta años tiene por hijos

Bernardo Choque de sinco años

Paula de quinse años años

Maria Aguilar de sinquenta años

Maria Caqueo de treinta años

Andrea Choque de veinte y ocho años

Josepha Choque de treinta años

Maria Garmendia de sinquenta años

Antonia Aguilar de treinta y sinco años tiene por hijo

Yldefonso Visa de siete años

Paula Cailaco de sinquenta años

Marzela Aguilar de ochenta años

[Foja 22v]

Josepha Choque de setenta años

Juana Flora de ochenta años

Casilda Asango de veinte años tiene por hijo

Marcelo de seis años

Gregoria Moya de sinquenta años

Maria Lopez de setenta años

Paula Aguilar de sinquenta años

Esperanza Ramires de setenta años

Catalina Quispe de veinte años 


\section{Huerfanos}

Narsiso Lopez de quinse años

Jossef Zambrano de catorze años

Eusevio Choque de ocho años

08

Thomas Gonzales de nuebe años

\section{$\underline{\text { Huerfanas }}$}

07

08

11

05

07

07
Alberta Visa de siete años
Lusia Veles de ocho años
Thomasa Ramires de onse años
Romualda Carbajal de sinco años
Marsela Carbajal de siete años
Magdalea Mamani de siete años
Thomasa Garmendia de siete años
Catalina Aguilar de dies y ocho años

\section{$\underline{\text { Cholos casados con tierras }}$}

Fransisco Gusman de veinte y seis años casado con

Petrona Choque de veinte y sinco años tiene por hijos

Manuel de vn año y quatro meses

\section{$\underline{\text { Solteros con tierras }}$}

Manuel Garcia de dies y ocho años

$\underline{\text { Viudas }}$

Ana Maita de quarenta y sinco años tiene por hijo

Fransisco Garcia de siete años

Padron del Pueblo de Esquiña

Originarios casados con tierras

Thomas Alabe (Principal) de quarenta y vn años casado

[Foja 23r]

Gregoria Guaiba de quarenta años

Agustin Nina de veinte y dos años casado con

Maria Lopez Albarado de veinte y quatro años

Pasqual Zanchez de quarenta y tres años casado con

Pheliciana Gonzales de treinta y nuebe años

Acencio Guampo de quarenta y tres años casado con

Angelina Lopez de treinta años

Basilio Thenal de quarenta y tres años casado con

Maria Theresa de treinta años

Roque Mamani de treinta y nuebe años casado

Juana Mendoza de quarenta años

Joseph Mamani de veinte y sinco años casado con

Maria Melchora Calle de treinta años tiene por hijo

Sebastian de sinco años

Sebastian Garcia de treinta y dos años casado con

Manuel de doze años

Thomas de ocho años 
40

Petrona Thenal de quarenta años tiene por hijos

Joseph de doze años

Simon de dos años

Casilda de catorze años

Petrona de ocho años

Ermenegildo Gonzales de veinte y dos años casado con

Lorenza Choque de veinte años

Fransisco Colque de veinte años casado con

Ana Mamani de treinta años tiene por hijos

Thomas de dos años

Gregorio Choque de veinte y vn años casado con

Ysidora Maria de veinte años

Ygancio Calle de veinte y dos años casado con

Gregoria Albornos de veinte y dos años tiene por hijos

Petrona de quatro años

Lucia de vn año

Jossef Miranda de quarenta y tres años casado con

Theresa Apasa de quarenta años tiene por hijos

Lucas de quatro años

[Foja 23v]

Maria de dies y ocho años

Ana de dies y seis años

Lucas Visa Guanca Chaya de quarenta y vn años casado

con Maria santos de treinta y nuebe años tiene por hijo

Juan de Dios de dies años

Yucas Calle de veinte y ocho años casado con
Yinaca de treinta años tiene por hijos

Marcos de ocho años

Ylario de seis años

Matias Canque de treinta y seis años casado con

Bartola Albaro de veinte y sinco años tiene por hijo

Mauricia de dies años = De otro Matrimonio

Pasqual Gonzales de quarenta y sinco años casado con

Crispina Mamani de treinta años

Pablo Amaro de veinte y nuebe años casado con

Marcela Colque de treinta años tiene por hija

Theresa de vn año

Silbestre Guampo de treinta y tres años casado con

Tiburcia Choque de treinta y sinco años

Silbestre Condori de treinta y dos años casado con

Ermenegilda Tarque de treinta y tres años tiene por hijos

Cruz de seis meses

Anastacia de siete años

Thomas Garcia de veinte y sinco años casado con

Rosa Chura de treinta y sinco años tiene por hijos

Juana de nuebe años

Maria de seis meses

Toribio Alabe de treinta años casado con

Estefania Mauricio de treinta y sinco años tiene por hijos

Justa de seis meses

Maria de dies años

Andres Cañavire de quarenta y tres años casado con

Maria Mollo de quarenta años tiene por hijo

Juan de ocho años

Pasqual Lopez de quarenta y vn años casado con

Maria Pasquala de quarenta años tiene por hijo

Lorenzo de vn año

Manuel Alabe de treinta y siete años casado con $\quad 37$

Bartola de treinta y sinco años tiene por hijos

Fransisco de quinse años 
Andres de nuebe años

[Foja 24r]

Carlos de vn año

Bernardo Choque de veinte y quatro años casado

Gertrudis Maria de veinte y quatro años

Miguel Guampo de veinte y sinco años casado con

Maria Cruz de veinte y quatro años

Agustin Velasco de quarenta y tres años casado con

Santusa Lopez de quarenta años tiene por hija

$06 \quad$ Lucia Velasco de seis años

Juan de Dios Choque de veinte y ocho años casado

con Bernarda Miranda de veinte y quatro años tiene por hijo

Nicolas de vn mes

Acencio Morales de quarenta y sinco años casado

Pasquala Casilda de quarenta años tiene por hijas

Angelina de dies y ocho años

16 Thomasa de dies y seis años

Gaspar Quispe de quarenta y vn años casado con

Maria Evgenia de quarenta años tien por hijos

$\begin{array}{ll}\text { Acencio de dies años } & 10\end{array}$

$\begin{array}{ll}\text { Diego de siete años } & 07\end{array}$

$\begin{array}{ll}\text { Andres de vn año } & 01\end{array}$

$04 \quad$ Gregoria de quatro años

Geronimo Tarque de quarenta y vn años casado con

Juana Quenaya de quarenta y sinco años tiene por hija

Maria Tarque de dies y seis años

Agustin Quispe de treinta y seis años casado con

Nicolasa Flores de treinta y sinco años tiene por hijos

Evsebio de ocho años

Juana Gonzales de quarenta años tiene por hijo

Narsiso de dose años

Pheliciano Morales de veinte y sinco años casado con 25

Barbara Albaro de veinte años

\section{$\underline{\text { Forasteros casados con Originarias con tierras }}$}

Diego Calle de treinta años natural de Carangas casado

Acencia Gonzalez de veinte y ocho años

Miguel Choque de treinta años al pareser natural de Carangas

casado con Rosa Thenal de treinta años

\section{[Foja 24v]}

Tiene por hijos

Cipriana de nuebe años

Theresa de siete años

Miguel Quispe de treinta y nuebe años al pareser casado con

Pasquala Mamani de veinte y seis años tiene por hijos

Crisostomo de seis años

Diego de ocho años

Roque Calle de Carangas al pareser de treinta y ocho años

casado con Rosa Gonzales de treinta y sinco tiene por hijos de dos

Matrimonios a

Evgenio de ocho años

Fransisca de tres años

Sebastian Veltran de Carangas al pareser de quarenta años

casado con Juana Gonzales de quarenta y sinco años tiene por hijos

Fransisco de catorze años

Thomas Ramos de Camiña al pareser de veinte y seis años

casado con Flora Choque de treinta y dos años tiene por hijos

Pedro de seis años 
00,9 Marcela de nuebe meses

Thomas Marca de veinte y sinco años al pareser de Carangas casado Crispina Guiza de veinte y sinco años tiene por hijos Andrea de vn año Pedro Visa de Carangas al pareser de veinte y sinco años casado con Lorenza Camacho de veinte y quatro años tiene por hijo a

Bernardo de vn año y seis meses

Thomas Mollo de Carangas al pareser de treinta años casado con Marcela Ramos de treinta y sinco años

Blas Guarachi de veinte y dos años pareser natural de Carangas

casado con Basilia Mamani de veinte años

Thomas Obando de Miñimiñi al pareser de dies y ocho años casado con Cecilia Amaro de dies y ocho años

Phelipe Carlos de Camiña al pareser de veinte años

\section{[Foja 25r]}

Maria Rosa de vn mes

Maria Magdalena de sinco años

Maria Manuela de vn año

\section{$\underline{\text { Forasteros casados con Forasteras sin tierras }}$}

Manuel Mamani de Carangas al pareser de veinte y siete años tiene por hijos

Gregoria de seis años

Magdalena de quatro años

$01 \quad$ Basilia de vn año

Joseph Mamani de Zibaya al pareser de veinte y dos años años tiene por hijos

Maria de quatro años

\section{Viudos originarios con tierras}




\section{Viudos Forasteros con tierras}

Phelipe Mollo de treinta y seis años natural de Turco

tiene por hijos

Fransisco de ocho años

Ildefonsa de seis años

\section{$\underline{\text { Solteros originarios con tierras }}$}

Antonio Choque de veinte y vn años

Pablo Mamani de veinte años

Juan Alejo de veinte y vn años

Melchor Choque de dies y ocho años

Andres Guampo de veinte años

Acencio Cutipa de veinte y dos años

Andres Calle de dies y ocho años

Diego Tarque de dies y ocho años

Geronimo Mamani de dies y ocho años

\section{Solteros Forasteros sin tierras}

Matias Quispe de dies y ocho años de Carangas

Antonio Colque de quarenta años de Carangas

\section{$\underline{\text { Reservados originarios }}$}

Diego Veles de sinquenta y dos años casado con

Maria Sisa de sesenta años

Silbestre Copa de sinquenta y nuebe años casado con

Maria Josepha de sesenta años tiene ella por hija a

20 Mauricia Tarque de veinte años

Sebastian Choque de sinquenta y dos años casado con

Maria Lima de sinquenta años tiene por hijos

18 Sebastiana de dies y ocho años

Andres Mamani de sesenta y tres años casado con $\quad 63$

Ana Colque de sesenta y sinco años

Melchor Valdes de sinquenta y tres años casado con

Maria Josepha Quispe de quarenta y sinco años tiene por hijos

\section{[Foja 26r]}

03 Juana de tres años

Martin Ninaja de sesenta años casado con

Maria Pheliciana de sinquenta y seis años

Sebastian Choque de sesenta años casado con

Andrea Gomes de sinquenta y ocho años tiene por hijo

Vizente Choque de dies años impedido

Pedro Chura de sinquenta años $\quad 50$

Nicolas Machaca de viente y dos años (tullido) 22

\section{Forasteros Reservados}

Juan Calle de Carangas al pareser de se[se]nta años casado

\section{Viudas}


06

40

14

12

60

45

45

07

12

Antonia de seis años

Juana Choque de quarenta años tiene por hijos

Santusa Choque de catorze años

Bernabela Mamani de doze años

Paula Visa de sesenta años

Josepha Mauricia de quarenta y sinco años

Maria Mamani de quarenta y sinco años tiene por hijos

Florentina Guanca de siete años

Rafael Guanca de siete años

Maria Guanca de doze años años

Maria Visa de quarenta y sinco años tiene por hijos

Manuel Cutipa de siete años

Anastacia Cutipa de tres años

Juana Guampa de quarenta años tiene por hijos

Lucas Thenal de seis años

Rosa Thenal de dies años

Ysabel Cayo de ochenta años

Paula Teresa de nobenta años

Paula Sisa de sesenta años

\section{[Foja 26v]}

Marta Copa de sinquenta años

Magdalena Chura de sinquenta años

Victoria Guampo de veinte y sinco años tiene por hijos

Fernando Guampo de vn año

Maria Colquema de quarenta años

Flora Mamani de ochenta años

Theresa Sisa de sesenta años

Maria Ysluga de sinquenta años

Maria Alabe de veinte y sinco años

Maria Barbara de treinta y sinco años

\section{$\underline{\text { Solteras }}$}

Lorenza Valdes de dies y ocho años tiene por hijo

Pedro de vn mes

\section{$\underline{\text { Huerfanos }}$}

Sebastian Mamani de doze años

Ambrosio de doze años

Justo Carnisero de dies años

Antonio de sinco años

Perfecto Mamani de catorze años

Pedro Pacci de doze años

Juan Lopez de ocho años

Xavier Mollo de nuebe años

Diego Ramos de trese años (Ciego)

$\underline{\text { Huerfanas }}$

Maria Miranda de quinze años

Petrona Guampo de dies y ocho años

Paula de dies años

Bartola Gonzales de dies y seis años

Basilia Mauricia de quinze años

Juana Calle de dies y seis años

Fransisca Calle de dies años

Tiburcia Mollo de dies años 


\section{$\underline{\text { Padron del Pueblo de Timar con tierras }}$}

Ygnacio Mamani de treinta años casado con Micaela

Huiba de veinte y seis años

Bartolome Cutipa de veinte y siete años casado con

[Foja 27r]

Marcelo de vn año

Basilio Garcia de veinte y quatro años casado con

Maria Guiba de veinte y dos años tiene por hija

Micaela Garcia de dos meses

Domingo Mamani de veinte y siete años casado con

Ysidora Garcia de veinte y nuebe años tiene por hijo

Matias de dies años

Gregorio Garcia de veinte y quatro años casado con 24

Barbara Laime de veinte años

Ysidro Miranda de veinte y dos años casado con

Andrea Buitron de veinte años tiene por hijos

Evgenio de tres años

Fransisco Mollo de quarenta y vn años casado con

Esperanza de la Cruz de treinta y nuebe años tiene por hijos

Sebastian de nuebe años

Benito de tres años

Phelipe Bargas de quarenta y seis años casado con Ma 46

[sic] Garcia de quarenta y tres años tiene por hijos

Marcos de onse años

Hilario Guaiba de quarenta y vn años casado con

Crispina Zarate de treinta y sinco años tiene por hijos

Lucas de trese años

Bartholo de ocho años

Fransisco de vn mes

Yldefonso Garcia de veinte y vn años casado con

Fransisca Ochoa de treinta y tres años - tiene por hijos a

= y ella de otro matrimonio a

Juana Mamani de onse años

Maria Lopez de treinta y siete años tiene por hijos

Lorenza de nuebe años

Ylaria de siete años

Juan Miranda de quarenta y seis años casado con

\section{[Foja 27v]}

Bernarda Garcia de quarenta y ocho años tiene por hijos

Diego de dies años

Jossef Mollo de veinte y sinco años casado con

Ermenegilda Romero de veinte y quatro años tien por hija

Josepha de tres años

Miguel Laime de veinte y sinco años casado con

Maria Sambrano de veinte y quatro años tiene por hija

Josepha de quatro años

Marcos Garcia de quarenta y vn años casado con

Thomasa Cutipa de quarenta años tiene por hijos

Basilio de nuebe años

Maria de onse años

Vrsula de siete años

Marcos Garcia de veinte y sinco años casado con

Rafaela Veles de veinte y tres años tiene por hijo a

Evsevio de vn año

Romualdo Buitron de treinta y dos años casado 
Maria Vasquez de treinta años tiene por hijos

Thomas de quatro años

Thedoro Losano de veinte y vn años casado con

Pheliciana Garcia de veinte años

Carlos Choque de veinte y ocho años casado con

Sebastiana Espejo de veinte años tiene por hijo

Santiago Choque de quatro años

Pasqual Cruz de quarenta y sinco años casado con 45

Maria Gomes de quarenta años tiene por hijos

Gerbacio de siete años

Antonio de dos años

\section{$\underline{\text { Forasteros casado con Originarias con tierras }}$}

Thomas Jaen Natural de Oruro al pareser de veinte años casado

Rosa Garcia Originaria de treinta y sinco años

\section{$\underline{\text { Solteros originarios con tierras }}$}

Ysidro Miranda de dies y ocho años

[Foja 28r]

\section{$\underline{\text { Reservados }}$}

Thomas Caque Losano de sinquenta y vn años

Diego Garcia de sinquenta y seis años casado con

Ana Ochoa de sesenta años tiene por hijos

Josepha de veinte y dos años

Micaela de veinte años

Juan Garcia de sinquenta y nuebe años casado con

Maria Sebastiana [de] sinquenta años tiene por hijos

Jazinta de siete años

Estefania de quatro años

Miguel Colque de sesenta años casado con

Esperanza Sisa de sinquenta años

\section{$\underline{\text { Viudas }}$}

Joseffa Quenaya de quarenta y sinco años tiene por hijos

Diego Apasa de onse años

Ygnacio Garcia de siete años

Phelipe de sinco años

Andrea de dies y seis años

Andrea de doze años

Maria de tres años

Esperanza Mamani de sinquenta años tiene por hijo a

Marcos de dies y siete años

Maria Lopez de sinquenta y sinco años

Esperanza Laime de sinquenta años tiene por hijos

Andrea de dies y ocho años

Agustina de veinte años

Pasquala Apasa de sesenta años tiene por hijos

Juan de siete años

Manuela de sinco años

Manuela Castro de quarenta y sinco años tiene por hijos

Thomas Buitron de dies años

Micaela Laime de quarenta y seis años tiene por hijo a

Juan de Dios Santos de dose años

Fransisca Mamani de quarenta y dos años tiene por hijos a

Matias de onse años 
Maria Santos de catorse años

Ana Sarate de quarenta y sinco años tiene por hijo a

Andres Garcia de catorse años

\section{[Foja 28v]}

Ana Flores de setenta años tiene por hijos

Rosa Aisa de catorse años

Ysabel Ramos de ochenta años tiene por hija a

Juana Laime de quarenta años

Petronila Veles de noventa años tiene por hijos a

Ana Flora de sinquenta años

Fransisca Ysabel de sinquenta años tiene por hijos a

Phelipe Castro de doze años

Gregoria Castro de veinte años

Pheliciana Calle de dies y ocho años

Jazinta Vernal de quarenta y seis años

Melchora Mamani de ochenta años = tiene por hija

Micaela de sinquenta años

Juana Zarate de sinquenta años tiene por hijos

Petrona Cutipa de treinta años

Antonia Garcia de trese años

Maria Buitron de quarenta y sinco años tiene por hijos

Gregorio Carbajal de siete años

Romualda Alanoca de nuebe años

Ysabel Buitron de dos años

Juana Zarate de ochenta años

Maria Cruz de quarenta y ocho años tiene por hijo a

Thomas de ocho años

Maria Vasques de quarenta y sinco años tiene por hijos

Bernardo Mamani de dies años

Juana Mamani de ocho años

Ana Mamani de catorze años

Maria Quenaya de sesenta años tiene por hijos

Agustina Sarabia de doze años

Ysidora Garcia de treinta y ocho años tiene por hijo a

Manuel Garcia de quatro años

Maria Miranda de quarenta años tiene por hijos

Juan de Dios de nuebe años

Prudencio de sinco años

Lorenza de siete años

Basilia de tres años

\section{Solteras}

Juana Cutipa de sinquenta años

Gertrudis Cutipa de quarenta años

\section{[Foja 29r]}

Maria Cutipa de treinta y sinco años

Ana Rojas de quarenta y sinco años

$\underline{\text { Huerfanos }}$

Bartolo Garcia de sinco años

Ygnacio Garcia de siete años 
06

02

07

08

Antonia Mamani de seis años Maria Gusman de dos años

Acencia de siete años Acencia Castro de ocho años Maria del Rosario de tres años

\section{$\underline{\text { Padron del Pueblo de Tignamar }}$ \\ $\underline{\text { Originarios casados con tierras }}$}

Ygnacio Guanca de treinta y tres años casado con

Marcela Mamani de treinta y vn años tiene por hijos

Salvador de vn año

Ysidora Guanca de tres años

Melchora de sinco años

Bentura Apas de quarenta y vn años casado con

Marcela Chura de quarenta años tiene por hijos

Blas de tres años

Juan de Dios de vn años

Ysabel de dose años

Pasquala de ocho años

Vizente Tarque de veinte y quatro años casado con

Dionicio Mamani de veinte y nuebe años casado con

Bernarda Nabe de veinte y seis años tiene por hijos

Norberto de vn año y seis meses

Magdalena de sinco años

Jossef Mamani de veinte y dos años casado con

Estefania [Foja 29v] Brisuela de veinte y quatro años tiene por hijo

Matheo de tres años

Phelipe Apas de quarenta y dos años casado con

Petrona Mamani de quarenta años tiene por hijo

Juan de doze años

Juan Cruz de veinte y quatro años casado con

Maria Carmen Calle de veinte y dos años tiene por hijo

Vizente de ocho meses

Juan Choque de treinta años casado con

Anami de quarenta y vn añ

Maria de dies y ocho años
Martin Santiago de quarenta y vn años casado con

Flora Brisuela de quarenta años

Miguel Mamani de treinta años casado con

Lorenza Zambrano de treinta años

Prudencio Garcia de veinte años casado con

Ylaria Nabe de veinte y dos años tiene por hijos

Clemente de ocho meses

Ramos Veles de veinte y sinco años casado con

Ysidora Choque de veinte y seis años

Josepha Guanca de quarenta años

Simon Calle de treinta años casado con

Magdalena Vedoya de veinte y nuebe años tiene por hijos

Petrona de ocho años

Santos Mamani de treinta años casado con

Petrona Espejo de veinte y ocho años tiene por hijos

Maria de tres años

Fransisco Tarque de quarenta y seis años casado con 
Fransisca de quarenta y tres años tiene por hijos

Juan Cruz de onse años

Juan de Dios de seis años

Luis de quatro años

Cecilia de dies y ocho años

Casilda de catorze años

$16 \quad$ Lucia de dies y seis años

02 [sic] Alberta de dose años

\section{[Foja 30r]}

Ylario Mamani de quarenta y tres años casado con

Casilda Mistu de quarenta y sinco años tiene por hijos

Phelipe de dies años

Thomasa de dies y nuebe años

Agustina de dies y siete años

Lopez Mamani de veinte y ocho años casado con

Bernarda Apaz de treinta años tiene por hijos

Maria de veinte años

Juana de dies y ocho años

Paula de ocho años

Lopez Valero de veinte y tres años casado con

Juana Mamani de veinte y sinco años

\section{$\underline{\text { Forasteros Casados con Originarias con tierras }}$}

Evsevio Gonzales de Carangas al pareser de treinta años

Gaspar Mollo de veinte y quatro años casado con

Monica Alanoca de veinte y sinco años tiene por hija

$01 \quad$ Dominga de vn año

Miguel Alanoca Mamani de Carangas al pareser de treinta y tres años 33

casado con Ana Alanoca de quarenta años tiene por hijos

Victorio de dose años

Ysidro de ocho años

Jualiana de tres años

Fransisco Baquero Mamani de quarenta y sinco años casado con

Esperanza Mamani de quarenta y sinco años tiene por hijos a

Cecilia de dies y ocho años= y ella de otro Matrimonio a

Maria de veinte y sinco años

Ysidro Apas de Ayaviri al pareser de veinte y ocho años

casado con Ysabel Calle de treinta y ocho años

\section{$\underline{\text { Solteros originarios con tierras }}$}

Cristobal Nabe de veinte años

Thomas Nabe de veinte años

[foja 30v]

Evgenio Choque de dies y nuebe

Vizente Mamani Guanca de dies y nuebe años

Basilio Calle de dies y ocho años

\section{$\underline{\text { Reservados }}$}

Evgenio Guanca de sinquenta años casado con

Maria Mamani Originaria de sinquenta y tres años

Gregorio Guanca de sinquenta y dos años casado con

Fransisca Guanca de sinquenta y vn años tiene por hijos

Bartolo de catorze

Martin Mamani de sinquenta y vn años casado con $\quad 51$

Maria Jossefa Mamani de quarenta y ocho años

Sebastian Mamani de sesenta años casado con 
50

52

61

60

66

Romualda Ramos de sinquenta años tiene por hijos Juan Mina de sinquenta y siete años casado con

Sebastiana Guarachi de sinquenta y dos años

Diego Lopez de sinquenta y ocho años casado con

Esperanza Josepha Lopez de sesenta y vn años

Bernardo Enrriques de setenta años casado con

Petrona Peña de sesenta años

Jossef Gomes de sinquenta años casado con

Maria Apas de sesenta años y seis años

Viudas

Jossefa Mamani de quarenta y tres años tiene por hijos

Agustin Lopez de doze años

Juan de Dios de dies años

Maria Lopez de catorse años

Maria Lopez de ocho años

Josepha Guarcaya de treinta y sinco años tiene por hijos

Acencio de siete años

Julian Calle de sinco años

Maria Calle de nuebe años

Feliciana Guanca de quarenta años tiene por hijos

Prudencio Gonzales de dies años

Cruz Gonzales de ocho años

Melchora Mamani de treinta y ocho años tiene por hijos

Rosa Nanabe de trese años

Marcela Mamani de ocho años

Rosa Condori de sinquenta años tiene por hijos

Thomas Mamani de dies y seis años

Rosa Cabana de sesenta años

\section{[Foja 31r]}

Maria Guarachi de sesenta y sinco años tiene por hija

Juana Mamani de treinta años

Ana Apaz de sesenta años

Maria Nina de sinquenta años tiene por hijos

Gregorio Soto de ocho años

Barbara Brisuela de dies años

Petrona Traque de treinta años

Flora Condori de quarenta años

Maria Ybañes de treinta años tiene por hijos

Melchor Ybañes de vn año

Bentura Crabajal de ocho años

Maria Mamani de treinta años tiene por hijos a

Esteban Mamani de dos años

Marta Mamani de quinse años

Victoria Mamani de doze años

Rosa Alanoca de sinquenta y sinco años

Santusa Calle de sinquenta años

Huerfanos

Crispin Nabe de ocho años

Tiburcio Gonzales de seis años

Phelipe Mamani de dies años

Gregorio Mamani de siete años

Crispin de sinco años

$\underline{\text { Huerfanas }}$ 
18

08

Juana de dies y ocho años

Paula de ocho años

\section{$\underline{\text { Cholos Huerfanos }}$}

Pedro Soto de dies años

Cholas Solteras

Maria del Carmen de veinte años

Pheliciana de dies y seis años

Victoria de doze años

Padron del ayllo de Guallatiri

Originarios casado con tierras

Diego Choque de quarenta y tres años casado con

Juana $\mathrm{Gu}$ [foja 31v] anca de quarenta y quatro años tiene por hijos

Matheo de dies años

Ysidora de catorze años

Maria de dies y ocho años

Acencio Choque de veinte y sinco años casado con

Rosa Mamani de veinte y tres años tiene por hija

Ysabel de dos años

Jossef Choque de quarenta y dos años casado con

Maria Ramos de quarenta y dos años tiene por hijos

Antonio de dies años

Stanislao de ocho años

Manuel de seis años

Melchora de dies y ocho años

Victoria de dose años

Ylario Lopez de quarenta y tres años casado con

Ysabel Guanca de quarenta años tiene por hijos

Mariana de doze años

Lasaro de sinco años

Joseph de tres años

Manuela de quinse años

Pedro calisaya de treinta y tres años casado con

Maria Mamani de quarenta y sinco años

Acencio Ubaldo de quarenta años casado con

Maria Mamani de treinta y ocho años

Manuel Colque de quarenta y tres años casado con

Ysidora Mamani de treinta y sinco años tiene por hijos

Andres de sinco años

Sebastian de vn año

Justo Ramos de veinte y sinco años casado con

Nicolasa Choque de treinta años tiene por hijos

Martin Mollo de veinte y sinco años casado con $\quad 25$

Maria Mamani de treinta años

Andres Mamani de veinte y sinco años casado

con Petrona Mollo de veinte y quatro años tiene por hijos

Manuel de tres años

Maria de vn mes

Antonio Mamani de veinte años casado con

Micaela Ramos de veinte años tiene por hijos

Santiago de tres años

Ventura de vn año

Agustin Ynquiltupa de treinta años casado con 
Bartola

Mamani de treinta y tres años

Fausto Mamani de treinta y vn años casado con

Rosa Calisaya de treinta y quatro años tiene por hijos a

Clemente de dos años

Ysidora de doze años

Sebastian de quinse años

Maria de dies y siete años

Sebastian Chambi de veinte y dos años casado con

Ysabel Mamani de veinte años tiene por hijos

Geronimo de sinco años

Ambrosio de tres años

Acencio Choque de treinta y sinco años casado con

Rosa Mamani de veinte y seis años tiene por hija a

Ysabel de vn año

\section{Forasteros Casados con Originarias con tierras}

Miguel Pacci de Carangas al pareser de treinta y dos casado

con Sebastiana Ramos de treinta años tiene por hijos

Diego de doze años

Juan de quinse años

Lucas de vn año

Maria de seis años

Thomas Flores de Carangas al pareser de treinta años

casado con Maria Paula de veinte y ocho años tiene por hijos

Pablo de quatro años

Silveria de doze años

Esperanza de sinco años

Esteban Mollo de Carangas al pareser de quarenta y sinco años

casado con Maria Flores de quarenta años tiene por hijos

Juan de doze años

Juana de quinze años

\section{$\underline{\text { Solteros }}$}

\section{[Manuscrito ilegible]}

Acencio Mollo de veinte y sinco años

[foja 32v]

Miguel Mamani de 40 años

\section{Reserbados}

Matheo Choque de sesenta y dos años casado con

Gregoria Mamani de sinquenta y ocho años

Lucas Atana de sinquenta años casado con

Maria Lopez de sinquenta años tiene por hijos

Cruza de dies y siete años

Paula de quinse años

\section{Viudas}

Maria Condori de sesenta años - tiene por hijos

Fransisco Ramos de catorze años

Andrea Colquema de sinquenta años

Maria Colquema de sinquenta y sinco años

Manuela Guanca de sinquenta años tiene por hijos

Gervacia de dies y ocho años

Dominga de trese años

Faustina Mamani de quinse años

Antonia Tapia de sinquenta y sinco años 


\section{$\underline{\text { Cholos casados con tierras }}$}

Fransisco Veles Abellaneda de 35 casado

Petrona Mamani Originaria de sinquenta años tiene ella por hijos

Maria Guancaya de dies y seis años

\section{$\underline{\text { Padron del Pueblo de Sacsamar sin tierras }}$}

Pedro Tarque de treinta y quatro años casado con

Petrona Mamani de treinta años tiene por hijos

Andres de siete años

Thomas de sinco años

Maria de nuebe años

Thomas Ylario de quarenta y quatro años casado con

Josepha Mamani de treinta y nuebe años tiene por hijos

Phelipe de catorze años

Manuel de doze años

Tiburcio Veles de treinta años casado con

Maria Sosa de treinta y ocho años tiene ella por hijas a

Evgenia de veinte años

Lorenza de dies y ocho años

Fransisco Cachaga de veinte y dos años casado con Ysidora

\section{[foja 33r]}

Sosa de veinte años tiene por hijos

Jossef de quatro años

Jazinto Mamani de veinte y quatro años casado con $\quad 24$

Maria Mamani de veinte y dos años tiene por hijos

Evsevio de ocho años

Petrona de seis años

\section{$\underline{\text { Viudos orginarios sin tierras }}$}

Pasqual Anaini de quarenta y quatro años tiene por hijos

Ygnacio de tres años

Maria de dies y seis años

\section{$\underline{\text { Solteros originarios sin tierras }}$}

Vizente Arequipa de veinte y dos años

Ygnacio Mamani Valero de dies y ocho años $\quad 18$

$\begin{array}{ll}\text { Silbestre Apasa de veinte y vn años } & 21\end{array}$

$\begin{array}{ll}\text { Matias Madueño de dies y ocho años } & 18\end{array}$

Matheo Cachaga de dies y nuebe años $\quad 19$

\section{$\underline{\text { Reserbados }}$}

Diego Alanoca de sinquenta y quatro años casado con $\quad 54$

Thomasa Cartagena de sinquenta y tres años

Sebastian Mamani y Cañipa de sinquenta y nuebe años

Maria de treinta y sinco años

Maria de treinta y vn años

Antonia de veinte años

\section{$\underline{\text { Forasteros casados con originarias sin tierras }}$}

Basilio Mamani de Carangas al pareser de treinta años 
06

00’7

07

06

09

Maria de seis años

[foja 33v]

Maria de siete meses

Fernando Colque de Paria al pareser de treinta y sinco años

casado con Marcela Viraca de treinta años tiene por hijos

Alberto de quatro años

Maria de siete años

Gregoria de seis años

Lucia de nuebe años

Acencia de vn año y seis meses

Lucas Mamani de Carangas al pareser de veinte y ocho años

casado con Rosa Madueño de treinta años tiene por hijos

Carlos de ocho años

Nicolas de quatro años

Fransisca de seis años

Luis Mamani al pareser de quarenta y quatro años casado

Silbestre de quinse años

Petrona de trese años

Magdalena de seis años

Agustina de tres años

\section{Viudos Forasteros sin tierras}

Andres Mamani de Carangas al pareser de veinte y siete años

Tiene por hijos

Casilda de tres años

Ana de vn año

\section{$\underline{\text { Reservados Forasteros }}$}

Ambrosio Mamani de Carangas al pareser de sesenta años casado con Maria Santos de sesenta y sinco años tiene por hijos Nicolas de dies años

Maria Manuela de dies y ocho años

Andres Cachaga de sinquenta años al pareser Natural de Ayaviri

casado con Pasquala Flora de sinquenta años

\section{$\underline{\text { Viudas originarias }}$}

Micaela Mamani de quarenta y sinco años tiene por hijo

Andres Mollo de catorze años

Cecilia Mamani de tres años

\section{[foja 34r]}

Paula Choque de quarenta años tiene por hijos

Martina Cañipa de catorse años

Juana Choque de sinquenta años tiene por hijos

Gregoria de veinte años

Rosa de catorze años

Fransisca Choque de veinte y seis años tiene por hijo

Pablo Mamani de dos años

Pasquala Mamani de treinta años tiene por hijos

Evsevio Flores de catorze años

Fransisco Xavier de tres años

Estefania Zerrano de sinquenta años tiene por hijos

Ysidro Santos de catorze años

Pasquala Viraca de quarenta años

Micaela Tarque de quarenta y sinco años tiene por hija

Evsevia Guanca de dos años

Melchora Aruquipa de sinquenta años tiene por hija

Fransisco Apasa de nuebe años 
Miguel Apasa de siete años

06

05

Maria de seis años

Marcela de sinco años

Juana Mamani de veinte años

\section{$\underline{\text { Huerfanos }}$}

Evsevio de ocho años

Dionicio Mamani de onse años

Prudencio Valero de nuebe años

Petrona de dies años

$\underline{\text { Huerfanas }}$

Gregoria de nuebe años

Bernarda de tres años

Maria Choque de vn año

Esperanza Mamani de dies y ocho años

Marcela Mamani dies y seis años

Evarista Mamani de dies años

Casilda de doze años

Padron del Pueblo de Pachama

Originarios casados con tierras

Pedro Nuñes de quarenta y vn años casado con Fransisca

[foja 34v]

Limachi de quarenta años = tiene por hija

Martina de dies años

Manuel Nunes de quarenta y quatro años casado con

Jossefa Molina de quarenta años tiene por hijos

Bernardo de dies años

Andrea de dies y ocho años

Andrea de doze años

Fernando Chura de treinta años casado con

Andrea Arubiri de treinta y dos años tiene por hijos

Manuel de nuebe años

$\begin{array}{ll}\text { Yldefonso de siete años } & 04\end{array}$

Pasquala de dos años

Lopez Chura de treinta y vn años casado con

Maria Carbajal de treinta y sinco años tiene por hijos

Crisostomo de tres años

Diego Mollo de treinta años casado con

Ysidora Copaja de treinta y sinco tiene por hijos a

Fernando de siete años

Diego Mollo de quarenta y nuebe años casado con

Maria Guanca de quarenta y ocho años tiene por hijos

Flora de ocho años

Lorenza de seis años

Sebastian Vasquez de quarenta y sinco años casado con

Esperanza Lanba de treinta años tiene por hijos

Bartolo de doze años

Matias Calle de veinte y siete años casado con

Antonia Garate de treinta años tiene por hijos

Acencio de vn año

Clemente Linco de veinte años casado con

Thomasa Mamani de veinte años

Fransisco Carbajal de veinte y ocho años casado con

Paula Ocsacopa de veinte y sinco años tiene por hijos

Fernando de doze años 
Bernardino de dies años $\quad 10$

Fransisco de siete años $\quad 07$

Fransisco de tres años $\quad 03$

Valeriano Ybañes de veinte y siete años casado con

Ermenegilda Vasquez de veinte y sinco años

Manuel Choqueguanca de treinta y tres años casado con

[foja 35r]

Thomasa Garcia de treinta y seis años tiene por hijos

Acencia de siete años

Miguel Tarque de veinte y ocho años casado con

Prudencia Arubiri de veinte y sinco años

Ambrosio Delgado de veinte años casado con

Maria Vara de veinte años

Diego Humiri de treinta y quatro años casado con

Paula Contreras de treinta y sinco años tiene por hijos

Pasquala de quinze años

Lorenza sinco años

Juana de dos años

Cruz Carbajal de veinte y seis años casado con

Phelicia Choque de veinte y sinco años tiene por hijos

Domingo de siete años

Andrea de quatro años

Pasquala de dos años

Diego Calle de quarenta y quatro años casado

Magdalena Quispe de sinquenta y tres años

Acencio Mamani de treinta años casado con

Cruza Vmiri de treinta y dos años tiene por hijos

Alejo de nuebe años

Augustin de seis años

Acencio de quatro años

Diego Sarsuri de veinte y nuebe años casado

con Jossefa Ramires de treinta años

\section{Originarios Viudos sin hijos y con Tierras}

Fransisco Vara de quarenta, y vn años

Pablo Ramires de treinta años

\section{$\underline{\text { Solteros }}$}

Nicolas Vmiri de dies y ocho años

German Chura de dies, y nuebe años

Jossef Larba de veinte y sinco años

Fransisco Arubiri de dies y ocho años

Faustino Tarque de dies y ocho años

Pasqual Vara de dies y nuebe años

\section{[foja 35v]}

Luis Nuñes de veinte años

Bartolo Basques de dies y ocho años

\section{$\underline{\text { Reservados }}$}

Fransisco Calle de sinquenta años casado con

Petrona Lopez Quiroga de quarenta y quatro años

Juan Chura de ochenta y quatro años casado con

Marta Orellano de sinquenta años tiene Ella por hijo a

Fernando de dies y seis años

Juan Cornejo de sinquenta, y siete años casado con 
09 [sic] Andres de nuebe años

Miguel Vara de sinquenta, y siete años casado con

Fransisca Agnocuti de quarenta años tiene por hija

Maria de dose años

Thomas Chuquiguanca de setenta y sinco años casado con

Petrona Apasa de sinquenta y ocho años

Tomas Ramires de sinquenta y sinco años

Melchor Ruis de sesenta años casado con

Rosa Quispe de sinquenta años tiene por hijo

Agustin de ocho años

\section{$\underline{\text { Forasteros Casados con originarias con Tierras }}$}

Manuel Coria de Totora Provincia de Carangas al pareser de

Treinta, y sinco años casado con

Micaela Arubiri de veinte y quatro años tiene por hijos

Maria de tres años

Agustin Flores de Tacna al pareser de veinte, y quatro años

casado con Lorenza Cayo de treinta, y sinco años

Diego Mamanni de veinte y sinco años casado con

Josepha Ramires de veinte y tres años

Martin Veles de Carangas al pareser de treinta y quatro años

casado Maria Chape de treinta y sinco años

\section{Forasteros Casados con Forasteras sin Tierras}

Juan Flores (Alias Macapire) de la Paz al pareser

\section{[foja 36r]}

de veinte años casado con Maria Abendaño

de Cosapa Provincia de Carangas de dies y ocho años

\section{$\underline{\text { Solteros Forasteros sin tierras }}$}

Melchor Choque de Carangas al pareser de veinte y sinco años 25

Melchor Condori de dies y ocho años $\quad 18$

Lasaro Choque de veinte y dos años $\quad 22$

Miguel Salas de Carangas al pareser de veinte y quatro años $\quad 24$

$\begin{array}{ll}\text { Melchor Chita de treinta años al pareser } & 30\end{array}$

\section{Viudas Originarias}

Maria Calle de sinquenta años

Maria Calle de quarenta y sinco años tiene por hijos

Pheliciano Molina de dies años

Petrona Chura de sinquenta años tiene por hijos

Andrea Arubiri de quinse años

Agustina de siete años

Maria Chura de quarenta años tiene por hijos

Ygnacio Vara de siete años

Maria Quispe de quarenta y tres años

Maria Chape de sinquenta años

Maria Thomasa de quarenta años tiene por hijos

Victorio Vara de dies y seis años

Leonora Aruquipa de sinquenta años tiene por hijos

Manuel Tarque de ocho años

Magdalena de dies y seis años

Rosa Mamani de quarenta años tiene por hija

Lucia de siete años

Acencia Apas de quarenta y sinco años tiene por hijos

Santiago Guanca del Zerro de catorse año

Nicolas Condori de seis años 
80

60

45

80

70

55

Ana Quispe de ochenta años

Bartola Gutierres de sesenta años

Maria Arubiri de quarenta y sinco años

[foja 36v]

Esperanza Choque de ochenta años

Andrea Guanca de setenta años

Esperanza Quispe de sinquenta y sinco años

Lucia del Zerro de sesenta y sinco años

\section{$\underline{\text { Solteras }}$}

Eulalia Veles de dies y ocho años

Santusa Condori de veinte años

Ana Chuquiguanca de veinte y sinco años

Polonia Mollo de veinte y sinco años

\section{$\underline{\text { Huerfanos }}$}

Crisostomo Chura de siete años

Manuel Miñi de quatro años

Matias Mamani de siete años

$\underline{\text { Huerfanas }}$

Santusa de nuebe años

Fransisca Mamani de ocho años

Dionicia Ocsa Copa de nuebe años

\section{$\underline{\text { Cholos casados con tierras }}$}

Juan Cuba mestiso casado con Gregoria Larba originaria de veinte y cuatro años tiene por hijos

Sebastiana Cuba de seis años

Dionicia Ocsa Copa de ocho meses

\section{$\underline{\text { Solteros Zambiagos con tierras }}$}

Jazinto Umajaia de dies y ocho años

Pheliciano Gusman de veinte y ocho años

Acencia Madueño de veinte y quatro años tiene por hijos

Bartola de dies años

Pasqual Guancaya de treinta y siete años casado con Cecilia

Colque de treinta años tiene el por hijos de otro Matrimonio a

[foja 37r]

Casildo de catorse años

Cipriano de onse años Y del presente Matrimonio a

Pedro de vn año

Andres Guailla Vaya de quarenta y vn años casado con

Acencia Limachi de treinta y sinco años tiene por hijos

Rosa de trese años

Petrona de siete años

Mateo Cruz de quarenta y vn años casado con

Marcela Vaya de treinta y seis años tiene por hija a

Tomasa de quinse años

Andres Quispe de treinta y quatro años casado con 
30

14

Maria Ara de treinta años tiene por hijos

Acencio de onse años

Micaela de catorse años

Pedro Alanoca de quarenta y tres años casado con

Andrea Madueño de quarenta años tiene por hijos

Ygnacio de dies y siete años

Mateo de dies y seis años

Bernardo Carrasco de treinta y nuebe años casado con 39

Maria Cruz de quarenta años tiene por hijos

Prudencio de catorse años

Roque de seis años

Maria de dose años

Gregoria de ocho años

Maria de trese años

Agustin Valla de quarenta y tres años casado con

Ana Mamani de quarenta años tiene por hijos

Pedro de catorse años

Evgenio Ara de veinte y quatro años casado con $\quad 24$

Maria Mamani de veinte y dos años

Manuel Vilca de dies y nuebe años casado con $\quad 19$

Gregoria Guancaya de dies y ocho años

Phelipe Dias de veinte y sinco años casado

con Ysidora Guancaya de beinte y sinco años tiene por hijos

Tiburcio de sinco años

Victoira de dos años

Nicolas Colque de veinte y dos años casado con

Manuela Mamani de veinte y ocho años tiene por hijos

\section{[foja 37v]}

Manuel de dies y seis años

Sebastian Viraca de quarenta y siete años casado con Ana 47

Espinosa de veinte y sinco años

$\begin{array}{ll}\text { Miguel Viraca de veinte años casado con } & 20\end{array}$

Manuela Condori de dies y ocho años

Crisostomo Guillermo Guanca de quarenta y nuebe años 49

casado con Esperanza Valla de quarenta años

Jossef Vaya de dies y nuebe años casado con

Maria Josepha Mollo de veinte y sinco años

Fransisco Quiros de veinte y vn años casado con

Maria Condori de veinte y sinco años

Carlos Mollo de quarenta y quatro años casado con $\quad 44$

Ylaria Limachi de quarenta y seis años

Cayetano Ramos de veinte y quatro años casado co

Crispina Anco de veinte y quatro años tiene por hijos

Andrea de sinco años

Bartola de vn año

\section{$\underline{\text { Forasteros Casados con Originarias con tierras }}$}

Pasqual Veles de Carangas al pareser de dies y ocho años casado con Manuela Mamani de diez y ocho años

\section{$\underline{\text { Solteros originarios con tierras }}$}

Bernardo Quispe de diez y ocho años

Fransisco Mamani de dies y ocho años

Luis Espinosa de dies y ocho años 


\section{Reservados}

Ramon Menacho de sinquenta y tres años

[Foja38r]

\section{Viudas}

00.3

07

Rosa Espinosa de treinta y seis años tiene por hijos

Benito Santos de ocho años

08

Narciso de seis años

Maria Calle de treinta años tiene por hijos

Jacinto Agnocuti de catorze años

Agustina de siete años

Barbara Rosa de setenta años

Petrona Mamani de sesenta y ocho años

Juana Espinosa de sesenta y ocho años

Flora Mundaca de quarenta años tiene por hijos

Jossef de seis años

Petrona Mamani de sesenta años

Lucia Quispe de veinte años tiene por hijos

Ignacio Quispe de un año seis meses

Paula Mamani de treinta años tiene por hijos

Silberia Dias de onse años

Maria Jossefa Bernal de tres años

\section{$\underline{\text { Solteras }}$}

Pasquala Limachi de treinta años tiene por hijos

Silveria de ocho años

Maria Josepha de seis años

Theresa Espinosa de veinte y ocho años tiene por hijos

Fransisco de ocho años

Benita Valla de quinse años tiene por hijo a

Manuel de vn año

Valentina Valla de veinte y dos años

Micaela Antonia de veinte años

Micaela Ana de catorse años

\section{$\underline{\text { Huerfanos }}$}

Fransisco Espinosa de seis años

Vizente Peres (mudo) de onse años

Bernardo Blanco de nuebe años

Nicolas Pari de nuebe años

Augustin Antonio Nuñes de quinse años

[foja38v]

Fausto Cañipa de ocho años

Julian Bueno de catorse años

Fransisco Mamani de dies y siete años

Ignacio Alanoca de dies y seis años

16

Diego Vilcanani de dies y siete años seis meses

6

\section{$\underline{\text { Huerfanas }}$}

Maria Carmen de tres meses

Maria Valla de siete años

\section{Cholos casados con tierras}


20

01

Josepha Vilcanani de veinte años tiene él por hijos de otro matrimonio

Antonio de siete años

Maria de vn año

Padrón del Pueblo de Libilca Originarios ca$\underline{\text { sados con tierras }}$

Diego Tarque de quarenta y un años casado con

Margarita Gusman de quarenta años tiene por hijos

Florentino de dies años

Mateo de siete años

Jossef Antonio de tres años

Manuela de dies y seis años

Flora de catorse años

Julian Mamani de quarenta y vn años casado con

Paula Mamani de treinta y dos años

Hilario Mamani de treinta y dos años casado con

Mariela Valla de treinta años tiene por hijos

Gregorio de vn año

Pedro Aruquipa de quarenta y vn años casado con

Pasquala Mamani de treinta y ocho años tiene por hijos

Narsiso de onse años

Vizente de tres años

y Flora de trese años

Ignacio Aruquipa de quarenta y vn años casado con

Francisca Albarado de veinte años tiene él por hijo de otro matrimonio

Manuel de dies años

Marcelo de seis años y del presente a

Valeriano de vn año

Santiago Veles de treinta y dos años casado con Maria 32

Ticona de quarenta años

Fiburcio Chuquita de treinta y ocho años casado con Ignacia

\section{[foja39r]}

Carlos de dos años

Martín Fernández de treinta y dos años casado con 32

Petrona Mamani de veinte años

Juan Clemente de treinta y siete años casado con

Eusebia Alanoca de treinta y siete años

Narciso Veles de veinte y seis años casado con

Lucia Tapia de veinte y sinco años tiene por hijos

Raimundo de seis meses

Lasaro Vinaca de veinte y seis años casado con

Ylania Santos de veinte y ocho años tiene por hijos

Atanacio de vn año

Martina de tres años

Fransisco Contreras de treinta y ocho años casado con

Bartholome Vinaca de treinta y dos años casado con

Pasquala Berrios de veinte y sinco años

Matheo Veles de treinta años casado con

Acencia Mamani de veinte y ocho años

Anselmo Alabe de dies y nuebe años casado con Maria

Vilcanani de veinte y quatro años tiene ella por hijos

de otro matrimonio a

Pedro Berrios de ocho años y del presente a

Norberto Alabe de vn año 
Barthola de tres años

$07 \quad$ Magdalena de siete años

Diego Guanca de treinta y vn años casado con

Micaela Santiago de veinte y sinco años $=$ tiene

por hijos de otro matrimonio a

Bernardo Guanca de siete años

Manuel Cañipa de quarenta y seis años casado con

Maria Carmen Vilcanani de quarenta años

tiene por hijos

Torivio Cañipa de ocho años

Maria de catorse años

\section{[foja39v]}

Ygnacio Guanca de veinte y siete años casado con

Esperanza Vinaca de veinte y sinco años tiene por hija a

Thomasa de siete años

\section{Forasteros casados con originarias con tierras}

Phelipe Mamani Catama de Cosapa al pareser de treinta inta y sinco años casado con Esperanza Garcia de treinta años tiene por hijos

Marcela de catorse años

Josepha de nuebe años

Juana de siete años

Rosa de quatro años

Diego Choque de Carangas al pareser de veinte y sinco años

Xavier Cusimamani de Calacoto al parecer de veinte

y sinco años casado con Maria Delgado de veinte y sinco

tiene por hijo a

Domingo de vn año $=$ y ella de otro matrimonio a

Margarita Delgado de nuebe años

\section{Viudos originarios con tierras}

Fausto Cañipa de quarenta y vn años tiene por hijos

\section{$\underline{\text { Solteros originarios con tierras }}$}

Faustino Aruquipa de dies y ocho años

Juan Guanca de veinte años

Prudencio Mamani de veinte y dos años

Fiburcio Cornejo de veinte y vn años

Paulino Flores de veinte años

Ermenegildo Guanca de dies y ocho años

Leonardo Veles de veinte y vn años

Gregorio Mamani de treinta años

[foja40r]

\section{$\underline{\text { Reservados }}$}


$\mathrm{y}$ tres años tiene por hijos

Gregorio de dies y siete años

Andres de dos años

Lucia de seis años

Juan Vinaca de sinquenta años casado con

Maria Chuquita de quarenta y ocho años tiene por hija

Paula de siete años

\section{Viudas}

Theresa de dies y seis años tiene por hija a

Matias de dos años

Maria Mamani de quarenta años tiene por hijos

Fransisco Guanca de sinco años

Marcela Guanca de quinse años

Isidora Guanca de trese años

Bernarda Guanca de dies y ocho años tiene por hijo

Gervacio de un año

Maria Agustina de sinquenta y vn años tiene por hijos

Bernardino Mamani de nuebe años

Esperanza Chino de quarenta y sinco años tiene por hijos

Jazinto Guanca de dies y siete años seis meses

Paula Guanca de catorse años [sic]

Josepha Alanoca de quarenta y sinco años tiene por hijos

Acencio Aruquipa de trese años

Petrona Alanoca de quarenta años

Catalina Caqui de sesenta años

Maria Tarque de treinta y sinco años tiene por hijos

Fernando de sinco años

Julian de dos años

Fransisca Mamani de sinquenta y ocho años

Maria Albando de sinquenta años

Cruza Veles de treinta años tiene por hijo

\section{[Foja40v]}

Maria Veles de siete años

Lorenza Colquema de setenta años

Fransisca Alanoca de sesenta años

Isabel Cañipa de treinta y sinco años tiene por hijo a

Eusevio Santiago de siete años

Maria Choqueta de sesenta y sinco años [sic]

Flora Contreras de sinquenta años tiene por hija

Dominga Santos de catorse años

Rosa Nina de sinquenta años

Paula Quispe de treinta y sinco años tiene por hija a

Manuela Quispe de doze años

Ana Manolla de setenta años

Paula Mamani de sesenta años

Maria Lucia de ochenta años

Petrona Mamani de quarenta y sinco años tiene por hijos

Martin Vilcanani de catorse años

Nicolas Vilcanani de onse años

Rosa Vilcanani de dies y seis años

Estefania Vilcanani de sinquenta años tiene por hija a

Pasquala Mamani de dies años

Bernarda Veles de treinta años $=$ tiene por hija a

Martina Carbajal de dos años

Andrea Ramos de treinta años

Melchora Mamani de quarenta y sinco años

Juana Delgado de quarenta años

Fransisca Tola de quarenta y sinco años tiene por hijos

Prudencio Ramos de dies y siete años 
Justino Ramos de trese años

Sebastian Ramos de nuebe años

Ana Limachi de sinquenta y sinco años

$40 \quad$ Agustina Mamani de quarenta años tiene por hijos

Fausto Mamani de catorse años

\section{$\underline{\text { Solteras }}$}

Rosa Vilcanani de treinta años

Maria Veles de veinte años

Bartola Limachi de catorse años

\section{$\underline{\text { Huerfanos }}$}

Faustino Ramos de trese años

\section{[Foja41r]}

Santos Veles de siete años

Fernando Quispe de siete años

Pasqual Escobar de quinse años

Tiburcio Veles de siete años

$\underline{\text { Huerfanas }}$

Juana Aruquipa de dose años

Maria Veles de catorse años

Bartola Limachi de siete años

\section{$\underline{\text { Cholos casados con tierras }}$}

Diego Artundaga de veinte y sinco años casado con

Gregoria Carlos Madueño de treinta años tiene por hijos

Martin de seis años

Santiago Gusman de treinta y sinco años casado con

Josepha Mamani de quarenta años tiene por hijos

Fransisco de onse años

Eugenia de catorse años

Clemente Soto de treinta años casado con

Juana Alanoca originaria de veinte y sinco años tiene por hijos

Fransisca de siete años

Silbestre Contreras mestiso casado con

Maria Madueño chola de veinte y sinco años

Ysidro Soto mestiso casado con

Margarita Vilcarí originaria de quarenta años

Bartolomé Tapia de veinte años 
Guillermo de doze años

Pedro de dos años

Marta de nuebe años

Martin Cusi de quarenta y vn años casado con

Marta Alanoca de quarenta años tiene por hijos

Isabel de ocho años

Juan de dos años

Andres Vasquez de quarenta y dos años casado con

Ana Cutipa de treinta años = tiene él por hijos

de otro matrimonio a

Ysidora de veinte años

Andrea de ocho años $=\mathrm{y}$ del presente a

Joseph de tres años

Ylaria de un año y seis meses

30.- Juana Guanca de treinta años tiene por hijos

Manuel Gaspar de un año y seis meses

Maria de seis años

Fransisca de tres años

Bartholome Guanca de quarenta años casado con

Valeriana de treinta años tiene por hijos

Jossef de ocho años

Dominga de sinco años

Maria Cutipa de veinte y sinco años tiene por hijos

Thomas de sinco años

Fransisco Marca de quarenta y ocho años casado con

Rosa Cutipa de treinta y sinco años tiene él por hijos

Ramos Calle de quarenta y tres años casado con

Petrona Ana de treinta años tiene por hijos

Andrea Calle de sinco años

Fransisco Mamani de veinte y dos años casado con

Rosa Gaspar de veinte años = tiene por hijos

[foja42r]

Jossef de seis años

$01 \quad$ Paula de vn año

Fernando Larba de treinta y un años casado con

Josepha Larba de treinta años tiene por hijos

Ilario de cuatro años

Nicolas de un mes

Jazinto Guanca de veinte y seis años casado con

María Santos de treinta y sinco años

Thomas Nina de quarenta y sinco años casado con

Santrusa Humirí de quarenta años tiene por hijos

Narsiso de dies y seis años

Fransisca de veinte años

Rosa de catorse años

María de cuatro años

Fransisco Ochanan de treinta y ocho años casado con

Rosa Cruz de treinta años tiene por hijo

Tiburcio de cinco años

Ildefonso de dos años

Antonio Nina de veinte y sinco años casado con

Rosa Tarque de veinte y sinco años tiene por hijos

Victoria de ocho años

$01 \quad$ Petrona de vn año

Baltazar Tarque de veinte y ocho años casado con 
Elena Orellano de veinte y quatro años tiene por hijos

Vizente de quatro años

Cayetana de seis meses

Agustin Cruz de veinte y quatro años casado con

Lorenza Larba de veinte años

Apolinar Nina de quarenta y vn años casado con

Barbara Larba de treinta y seis años tiene por hijos

Juan de nuebe años

Thomas Totora Cruz de veinte años casado con

Petrona Cusi de dies y ocho años tiene por hija

Melchora Cruz de vn año

\section{[Foja42v]}

Baltazar Gomes Flores de dies y ocho años casado con

Eugenia Calle de dies y siete años

Silvestre Marca de veinte y quatro años casado con

Ignacia Cruz de veinte y tres años tiene por hijo

Phelipe de dos años

Pedro Guanca de veinte y dos años casado con

Manuela Calle de veinte años

Agustín Mamani de veite y sinco años casado con

María Mamani de veinte y quatro años

Pedro Larba de veinte y siete años casado con

Pasquala Vasquez de veinte y quatro años tiene por hijo

Torivio de un año

Juan Jossef Oronos de quarenta y un años casado con

Petrona Nina de treinta y sinco años

Fernando Choque de quarenta y dos años casado con

Ylaria Condori de treinta años tiene por hija de otro matrimonio el a

Tiburcia de dies y ocho años y del presente a

Maria Choque de ocho meses

Jossef Calle de veinte años casado con

Rosa Nina de dies y ocho años tiene por hija

Eusevia de seis meses

Fransisco Villanueba de treinta y sinco años casado con

Pheliciana Tarque de treinta años tiene por hijos

Fransisco de dies años

Thomas Mamani de treinta y sinco años casado con

Paula Rojas de treinta años tiene por hija

$04 \quad$ Lucia de quatro años

Thomas Apas (moso) de treinta y vn años casado con

Marcela Yugra de veinte y seis años

Petrona Agnocuti de veinte años tiene por hijo

Marcos Tarque de treinta y vn años casado con

[Foja43r]

\section{$\underline{\text { Forasteros casados con originarias con tierras }}$}


20

sinco años casado con Paula Castro de veinte años

Carlos Valeriano de Carangas al pareser de veinte y sinco

años casado con Petrona Flores de veinte y quatro años

tiene por hijos a

Ylario de dies años

Tiburcio de seis años

06

$\begin{array}{ll}\text { Bernardo de quatro años } & 04\end{array}$

Santusa de ocho años

Ylario Zanches de Carangas al pareser de veinte y tres

años casado con Acencia Humiri de veinte y

quatro años tiene por hijos a

Maria de seis años

Santusa de quatro años

Jossefa de dos años

\section{Viudos originarios con tierras}

Miguel Gaspar de treinta y quatro años tiene por hijos $\quad 34$

$\begin{array}{ll}\text { Bernardo de seis años } & 06\end{array}$

Juana de siete años

Acencio Cusi de veinte y dos años tiene por hijos $\quad 22$

Jossef de dos meses

\section{$\underline{\text { Solteros originarios con tierras }}$}

$\begin{array}{ll}\text { Thomas Marca de dies y ocho años } & 18\end{array}$

$\begin{array}{ll}\text { Gregorio Calle de dies y ocho años } & 18\end{array}$

[Foja43v]

$\begin{array}{ll}\text { Rafael Nina de dies y ocho años } & 18\end{array}$

Pedro Guanca de dies y ocho años $\quad 18$

$\begin{array}{ll}\text { Phelipe Mollo de dies y ocho años } & 18\end{array}$

Pablo Maquera de veinte y dos $\quad 22$

Martin Maquera de dies y ocho años $\quad 18$

Antonio Guanca de dies y nuebe años $\quad 19$

$\begin{array}{ll}\text { Nolasco Apaz de dies y ocho años } & 18\end{array}$

$\begin{array}{ll}\text { Phelipe Tanque de dies y ocho años } & 18\end{array}$

$\begin{array}{ll}\text { Fernando Vasquez de dies y ocho años } & 18\end{array}$

Phelipe Choque de dies y ocho años $\quad 18$

Cruz Vasquez Ferran de dies y ocho años $\quad 18$

$\begin{array}{ll}\text { Crispin Mamani de veinte años } & 20\end{array}$

$\begin{array}{ll}\text { Fiburcio Santos de veinte y un años } & 21\end{array}$

\section{$\underline{\text { Reservados }}$}

Ambrosio Choque de sinquenta y tres años tiene por hijos $\quad 53$

$\begin{array}{ll}\text { Silbestre de ocho años } & 08\end{array}$

$\begin{array}{ll}\text { Pedro de quatro años } & 04\end{array}$

Barbara de seis años

Thomas Apas de sinquenta y sinco años casado con

Maria de veinte y sinco años

Diego Nina de sinquenta y ocho años casado con $\quad 58$

Maria Josepha de sinquenta y tres años tiene por hijos

Fransisco de dies años

Tomasina de dose años

Lorenza de catorse años

Sebastian Tarque de sinquenta y vn años casado con $\quad 51$

Maria Cutipa de quarenta y cinco años

Augustin Tarque de sinquenta y tres años casado con $\quad 53$

Micaela Mamani de quarenta años

Acencio Larba de sinquenta y sinco años casado con 
50

Maria Romero de sinquenta años

[Foja44r]

Ysidro Guanca de sesenta y nuebe años casado con

Ysabel Medina de sesenta años.

\section{Viudas}

Fransisca Tarque de quarenta años tiene por hijos

Juana Marca de quinse años

Maria de siete años

Maria Thomasa de sinquenta años tiene por hijos

Pedro Mollo de dies y siete años

Xavier Mollo de trese años

Micaela Vasquez de sinquenta años

Fransisca Gaspar de treinta años

Pasquala Choque de sinquenta y sinco años tiene por

hijos

Fernando Mamani de onse años

Maria Castro de veinte años

Thomasa Castro de quinse años

Esperanza de ocho años

Maria Flora de sinquenta años tiene por hija

Maria Mamani de veinte años

Ana Aira de sesenta años tiene por hija a

Gregoria Arellano de veinte y sinco años

Andrea Puma de sesenta y sinco años

Ana Carbajal de setenta años

Ana Flora de ochenta años

Acencia Choque de treinta y sinco años tiene por hijos

Ysidro Marca de seis años

Gregoria Marca de ocho años

Bartola Zanches de sinquenta años

Casilda Chuna de quarenta años tiene por hijo

Jossef Larba de dies y seis años

Casilda Calle de quarenta y sinco años

Fransisca Choque de sinquenta años tiene por hija

Eugenia Choque de dies y seis años

Fransisca Cutipa de sesenta años

Fransisca Larba de sinquenta años

[Foja44v]

Fransisca Alanoca de sinquenta y seis años tiene por hijos

Maria Condori de veinte años

Fransisca Condori de dies y ocho años

Pheliciana [manuscrito ilegible] de setenta años

Fransisca Ferran de quarenta años tiene por hijo

Santos de un año

Jossefa Buitron de sesenta años

Juana Mistu de sesenta y sinco años

Juana Larba de setenta años

Juana Calle de sinquenta años tiene por hija a

Ignacia Larba de dies y ocho años

Juana Larba de sinquenta y sinco años tiene por hijos

Antonio de catorze años

Fransisca Guanca de dies y ocho años

Juana Cutipa de dies y seis años

Joseffa Cutipa de sinquenta años tiene por hijos

Pedro Condori de dies y seis años

Gregoria de dies y ocho años

Ysabel Mollo de sinquenta y sinco años tiene por hija

Ysidora Mollo de veinte y sinco años 
Maria Calle de sinquenta y seis años tiene por hijos

Fransisca Larba de veinte y seis años

Lucia Larba de veinte años

Maria Buitron de sesenta años

Maria Cruz de nobenta años tiene por hija

Maria Garcia de sinquenta años

Maria Larba de setenta años

Maria Nina de quarenta años

Maria Nina de setenta años

Magdalena Nina de sinquenta años

Micaela Mamani de setenta años

Marcela Cusi de quarenta y sinco años

Maria Cutipa de sinquenta años

Maria Vasquez de setenta años tiene por hija a

Ubalda Tanque de veinte años

\section{$\underline{\text { Solteras }}$}

Esperanza Vasquez Guanca de veinte años

Fransisca Cutipa de quarenta años

\section{[Foja45r]}

Pheliciana Dias de veinte años

Manuela Larba de treinta años

Maria Carmen de veinte y sinco años tiene por hijo

Acencio de dos años

Maria Acencia de treinta y sinco años tiene por hijos

Nicolas Santos de dose años

Maria Santos de nuebe años

$\underline{\text { Huerfanos }}$

Nicolas Tarque de siete años

Thomas Larba de sinco años

Juana [sic] Guanca de trese años

Pedro Ramires de seis años

Juan Calle de doze años

Huerfanas

Romualda Ferran de doze años

Maria Flora de quatro años

Casilda Cutipa de dos años

Maria Mamani de quatro años

Tiburcia Nina de quatro años

Maria Nina de quatro años

Maria Cutipa de dies y seis años

Eugenia de ocho meses

\section{Padron del Aillo Aransaya de Belen Originarios casados con tierras}

Ilario Ramos (principal) de quarenta años casado con

Petrona Guanca de veinte y ocho años

Juan Cutipa de treinta y un años casado con

Maria Choque de treinta y tres años

Fransisco Larba Garcia de quarenta y un años casado con

Gervacia Cusi de treinta nuebe años

Jossef Larba de treinta y dos años casado con

Maria Cusi de treinta y sinco años tiene por hijos

Simon de quatro años 
05

01

Juana de sinco años

Marta de vn año

[Foja45v]

Ramos Larba de treinta y dos años casado con

Maria Marca de treinta años tiene por hijos

Eduardo de ocho años

Fernando de seis años

Thomas de sinco años

Pasquala de vn año

Antonio Larba de quarenta y seis años casado con

Maria Guanca de quarenta años tiene por hijos

Eugenio de dies años

Pheliciana de ocho años

Ambrosio de sinco años [sic]

Maria Josepha de doze años

Lorenza de un año

Evarista de tres años

Juan Contreras de treinta años casado con

Estefania Marca de veinte años tiene por hijos

Jossef de seis meses

Juan Calle de quarenta y quatro años casado con

Ana Larba de quarenta años tiene por hijos

Maria de dies y siete años

Fernando Calle de quarenta y un años casado con

Ma ria Tarque de treinta y sinco años tiene por hija a

Clara de catorse años

Florentino Calle de quarenta años casado con

Ana Cutipa de treinta años tiene por hijos

Thomas de dose años

Pablo de siete años

Pheliciana de vn año

Sebastian Tarque de treinta y dos años casado con

Andrea Cruz de treinta años tiene por hijos

Juan Tarque de sinco años

Pedro Aguilar de quarenta y vn años casado con

Maria Agnocuti de treinta y sinco años tiene por hijos

Gregorio de dies años

Pheliciana de catorse años

con Casilda Nina de treinta años tiene por hijos

Anselmo de quatro años

Narsiso Cutipa de quarenta y un años casado con Gregoria

Larba de quarenta años tiene por hijos ella de otro matrimonio a

[Foja46r]

Nicomedes Marca de dies años = y del presente

Ambrosio Cutipa de ocho años

Mariano de dos meses

Marta de sinco años

Miguel Orellana de quarenta y sinco años casado con

Barbara de veinte y ocho años [sic]

Santiago Cutipa de quarenta y vn años casado con

Maria Tarque de treinta y ocho años tiene por hijos

Roque de dos años

Juliana de veinte años

Antonia de siete años

Marcos Larba de treinta años casado con

Maria Romero de treinta años tiene por hijos

Fransisca de quatro años

Garcia Calle de quarenta y quatro años casado con 
Maria Ramos de veinte y cinco años

Jossef Larba de treinta y un años casado con

Isabel Cruz de treinta años tiene por hijos

Fransisco de doze años

Andres de ocho años

Marcos de seis años

Acencia de vn mes

Crisostomo Larba de veinte y nuebe años casado con

Ana Larba de veinte y cinco años

Gregorio Vasquez de veinte y seis años casado con

Pheliciana Cusi de veinte y sinco años tiene por hijos

$01 \quad$ Esperanza Vasquez de vn año

Florentino Nina de veinte y ocho años casado con

Esperanza Condori de veinte y seis años tiene por hijos

Fransisco de siete años

Salvador de sinco años

Ana de nuebe años

Jossef Agnocuti de veinte y dos años casado con

Santusa Choque de treinta años

Miguel Calle de veinte y dos años casado con

Isabel Tarque de dies y ocho años

Tomas Vega de treinta y cinco años casado con

[Foja46v]

Casilda Tarque de treinta años tiene por hijos

Casilda Vega de ocho meses

Alejandro Cruz de treinta años casado con

Gervacia Larba de veinte y ocho años tiene por hija

Fransisca de tres años

Jossef Cutipa de veinte años casado con

Barbara Vasquez de dies y ocho años tiene por hijo

Fransisco Cutipa de dies meses

Juan Cruz de quarenta y cinco años casado con

Maria Calle de veinte y cinco años tiene el por hija de otro

matrimonio a

Evarista de dies y seis años $=$ y la muger a

Santiago Larba de dies años

Florentino Guanca Madueño de veinte años casa

do con Rosa Larba de dies y ocho años

Acensia Larba de dies y nuebe años tiene por hijo a

$1900.10 \quad$ Maria Miranda de dies meses

Carlos Larba de veinte y siete años casado con

Melchora Marca de veinte años

Maria Orellana de veinte años

Toribio Cutipa de veinte y ocho años casado con

Juana Larba de veinte y cinco años tiene por hijos

Maria de quatro años

Angelina de dos años

Petrona de dos meses

Pedro Orellana de quarenta y vn años casado con

Maria Bustos de treinta y cinco años tiene por hijos

Juan de seis años

Phelipe Larba de treinta y dos años casado con

Maria Nina de treinta años tiene por hijos

$03 \quad$ Ana de tres años

Pedro Xavier Larba de veinte años casado con 
[Foja47r]

Acencio Mamani de treinta y ocho años casado con 38

Cruza Umiri de quarenta y sinco años tiene por hijos

Pedro de siete años

Juan de sinco años

Eusevio de vn año

Thomas Flores de treinta y sinco años casado con $\quad 35$

Polonia Gutierres de treinta y quatro años

Julian Madueño Guanca de veinte y dos años casado con

Maria de veinte años

\section{Forasteros casados con originarias con tierras}

Jossef Bustos de Cosapa al pareser de treinta y nuebe años casado con Maria Nina de quarenta años tiene por hijos ella de otro matrimonio a

Fransisca Guanca de onse años

Paquala Guanca de nuebe años

Petrona Guanca de seis años $=\mathrm{y}$ del presente $=$

Teresa de sinco años

Manuel Gomes de Carangas al pareser de treinta años

casado con Marcela Cutipa de veinte y sinco años

\section{Viudos originarios con tierras}

Domingo Choque de quarenta y seis años tiene por hija

Juana de veinte años

\section{$\underline{\text { Solteros originarios con tierras }}$}

Jossef Orellana de veinte años

Santiago Larba de dies y ocho años

Ilario Larba de veinte años

Blas Cutipa de veinte años

Jossef Mamani de dies y ocho años

\section{$\underline{\text { Reservados }}$}

Santiago Nina (tullido) de treinta y ocho años casado con

[Manuscrito ilegible] de catorse años

Maria de dies y seis año

Diego Nina de sinquenta y ocho años casado con Maria

Josepha de sinquenta y tres años tien por hijos

Fransisco de dies años

Tomasina de dose años

14 Leonarda de catorse años

Fransisco Larba de sesenta y vn años casado con Maria Ma

mani de sesenta y tres años

$\underline{\text { Viudas }}$ 
60

20

70

85

60

70

40

60

45

100

80

50

10

Rosa Vasquez de sesenta años tiene por hija a

Maria Ferran de veinte años

Rosa Vasquez de setenta años

Rosa Aisa de ochenta y sinco años

Rosa Alanoca de sesenta años

Sebastiana Ramos de setenta años

Isabel Cusi de quarenta años

Esperanza Choque de sesenta años

Magdalena Vasquez de quarenta y sinco años

Maria Lopez de cien años

Andrea Puma de ochenta años

Lucia Apasa de sinquenta años tiene por hijos

Fransisco Carbajal de ocho años

Maria Rosa de dies años

Nicolasa Colquema de quarenta y cinco años tiene por hijos

Diego Mamani de ocho años

Vizente Mamani de seis años

Lazaro Mamani de vn mes

Teresa Colquema de quinse años

Fransisca Tarque de setenta y sinco años

Ana Apara de sinquenta años

Catalina Ramires de setenta años

Esperanza Cañipa de sinquenta y sinco años

Micaela Romero de sinquenta años $=$ tiene por hijos en cholos $=$

\section{$\underline{\text { Huerfanos }}$}

Matias Larba de sies y siete años

[Foja48r]

\section{$\underline{\text { Huerfanas }}$}

Marcelina Madueño de dies y ocho años

Maria Rocaful de catorze años

Casilda Tarque de veinte años

\section{Cholos casados con tierras}

Thomas Zanches mestiso casado con Pasquala Cruz originaria de treinta y sinco años tiene por hijos Mariano de seis años

Maria de dies años

Ana de tres años

Tiburcia de ocho meses

\section{Cholos solteros con tierras propias}

Pedro Casildo Contreras de veinte y sinco años $\quad 25$

$\begin{array}{ll}\text { Isidro Contreras de dies y ocho años } & 18\end{array}$

Estos estan provando no serlo sino mestisos $=$

\section{Padron del Pueblo de Socoroma Altos de Arica-casados con tierras}

Don Esteban Gutierres segunda perzona de casique de treinta y un años casado con Marcela Lobera de treinta y sinco años tiene por hijos

Maria de dies años

Maria de ocho años

Estefania de seis años 
04

Rogenia de quatro años

Juliana de dos años

Fransisco Marsella de quarenta y dos años casado con

Cruza Mamani de quarenta y quatro años tiene por hijos

Alejandro de catorze años

Thomas de doze años

Maria de quatro años

Valentina de quatro meses

Acencio Vasquez de treinta y vn años casado con Maria

Alanoca de treinta años = tiene por hijo

Ignacio de catorse años

[Foja48v]

Acencio Ramos de quarenta y seis años casado con

Petrona Manclla de quarenta y ocho años tiene por hijos

Ildefonso de trese años

Eugenio de siete años

Ana Ramos de veinte años

Maria de quinse años

Gregoria de tres años

Agustin Humiri de veinte y sinco años casado con

Teresa Condori de veinte y quatro años tiene por hijos

Antonio de siete años

Lorenzo de vn año

Antonio Choque de quarenta y seis años casado con

Ana Humiri de sinquenta y siete años tiene por hijos

Andrea de veinte años

Acencio Rafael de veinte y dos años casado con

Polonia Humiri de veinte y cuatro años tiene por hijo a

Thomas de dos meses

Alberto Gutierres de treinta y vn años casado con

Isabel Valencia de treinta años tiene por hijos

Fransisco de seis años

Maria de onse años

Thomasina de dos meses

Bartolome Umiri de quarenta y vn años casado con

Maria Cusi Mamani de treinta años tiene por hijos a

Diego de siete años

Lorenzo de vn año y seis meses

Isabel de dies años

Ilaria de tres años

Cruz Blanco de quarenta años casado con

Pasquala Condori de treinta y nuebe años tiene por hijos

Ilario de seis años

Bernarda de seis meses

Diego Chuquiguanca de quarenta y seis años casado con

Blasa de veinte años

Theodora de quatro años

Fransisco Flores de quarenta y dos años casado con

Maria Manclla de quarenta años tiene por hijos

Mariano Salvador de catorse años

Anastacia de quinse años

\section{[Foja49r]}

Pheliciano Yugna de veinte y quatro años casado con

Marta Condori de veinte y tres años tiene por hijos

Theodoro de dies y ocho meses

Pasqual Cutipa de quarenta y vn años casado con 
Rosa de catorze años

Ilario Guanca de veinte y dos años casado con

Antonia Mamani de veinte y quatro años tiene por hijos

Justo de seis años

Ignocencio Flores de quarenta y quatro años casado con

Juana Pasquala Chinchilla de quarenta y tres años

tiene por hijos

Juan de ocho años

Maria de sinco años

Jossef Humiri de veinte y ocho años casado con

Petrona Gutierres de treinta años tiene por hijos

Melchora de siete años

$01 \quad$ Maria de un año

Julian Mamani de quarenta y dos años casado con

Maria Carrasco de quarenta y quatro años tiene por hijos

Blas de trese años

Silvestre de siete años

Juan de vn año

Narsisa de onse años

Lasaro Gutierres de veinte y ocho años casado con

Pasquala Machaca de treinta años

Laureano Guanca de quarenta y ocho años casado con

Maria Umiri de quarenta y ocho años tiene por hijos

Ildefonso de trese años

Geronimo de sinco años

Martin de tres años

Dominga de veinte años

Magdalena de dies y ocho años

Monica de dies y seis años

\section{[Foja49v]}

Polonia de quatro años

Lasaro Cutipa de quarenta y vn años casado con

Estefania Flores de quarenta años tiene por hijos

Tiburcio de dose años

Esperanza de veinte y dos años

Fransisca de dies y ocho años

Lucas Guanca de quarenta y quatro años casado con

Pasquala Manclla de quarenta y un años tiene

por hijos

Zipriano de dose años

Juana de dies y seis años

14 Pasquala de catorze años

Miguel Guanca de veinte y dos años casado con

Magdalena Gutierres de veinte años

Sebastian Guanca de veinte y siete años casado con

Maria Mamani de veinte y ocho años

Prudencio Condori de veinte y dos años casado con

Juan de sinco años

Estefania de quatro meses

00.4

Santos Fernandes de quarenta y nuebe años casado con

Juana Mamani de quarenta años tiene por hijos

20 Cecilia de veinte años

Zeverino Cutipa de veinte y ocho años casado con

Josepha Flores de treinta años tiene por hijos

Maria de vn año

Salvador Quispe de treinta y quatro años casado con

Lucia Vaya de treinta y ocho años tiene ella por hijos

Anastacia Fernandes de quinse años $=\mathrm{y}$ del presente

Luis Quispe de dies años

Sebastian Albarado de veinte y tres años casado con 
Isabel Castillo de veinte y ocho años tiene por hijos

Jossef de dies años

Julian de quatro años

Maria de seis años

\section{[Foja50r]}

Sebastian Valencia de veinte y ocho años casado con

Esperanza Calamollo de treinta y sinco años

tiene por hijos

Fulgencio de quatro años

Romualda de siete años

Tadeo Carrasco de quarenta y un años casado con

Maria Gutierres de treinta y ocho años tiene por hijos

Fransisco de onse años

Nicolas de quatro años

Cruza de siete años

$00.1 \quad$ Eustaquia de vn mes

Tiburcio Manclla de veinte y dos años casado con

Maria Limachi de veinte años

Ignacio Tapia de quarenta y siete años casado con

Andrea Flores de sinquenta años tiene por hijos

Juana Condori de treinta años

Fransisco Ramos de veinte y dos años casado con

Paula Guanca de treinta años tiene por hijos

Pheliciana de un año

Pasquala de quatro años

Basilio Gutierres de veinte años casado con

Rosa Cusi Mamani de dies y nuebe años

Bernardo Flores de veinte y dos años casado con

Andrea Humiri de veinte y un años

Santos Mamani de treinta años casado con

Paula Maita de treinta años tiene por hijos

Ignacio de tres años

Acencia de dos años

Nicolas Flores de treinta años casado con

Tomasina Yugra de treinta y sinco años tiene por hijos

Andres de onse años

Melchora de quatro años

$01 \quad$ Nicolasa de un año

Florentino Alanoca de veinte y quatro años casado con

Ana Lopez de veinte y sinco años tiene por hijo

Valeriano de dos años

Cayetano Contreras de quarenta y un años casado con

[Foja50v]

Andrea Machaca de quarenta años

Marcela Gutierres de treinta y ocho años tiene por hija

Gregoria de dose años

Juan de la Cruz Bolaños de treinta y tres años casado con

Maria Flores de treinta años tiene por hijos

Domingo de dies y seis años

Mariano de catorse años

Manuela de doze años

10 Maria Cruz de dies años

Lorenzo Chinchilla de quarenta y vn años casado con

Magdalena Miranda de veinte años tiene por hijos

Fransisco de quatro meses $=\mathrm{y}$ de otro matrimonio el dicho a

Eusevia de doze años 
35

40

Blanco de treinta y sinco años

Jossef Mamani de dies y ocho años casado con

Thomasina Choque de quarenta años tiene por hija

Eugenia Quispe de catorse años

\section{Forasteros casados con originarias, $\underline{\text { con tierras }}$}

Diego Mamani de Calacoto al pareser de treinta años casado con

Maria Sira de treinta años tiene por hija

Rosalia de quatro años

Julian Gonzales al pareser de treinta y tres años casado con

Flora Mistu de quarenta años tiene ella por hijos

de otro matrimonio a

Ignacio Manclla de trese años

Maria de dies y ocho años

Matheo Baptista de Calacoto al pareser de treinta y quatro

ños casado con Juana Manclla de treinta y sinco años

tiene por hijos

Salvador de sinco años

Jazinta de vn año

Melchor Vasquez de Cosapa al pareser de veinte y quatro años

casado con Maria Valencia de veinte y sinco años tiene

por hijos

\section{[Foja51r]}

Bernardo de quatro años

$\begin{array}{ll}\text { Mariano de dos años seis meses } & 02.6\end{array}$

Simona de tres años

Lorenzo Vasquez de Carangas al pareser de quarenta años

Bartolome Choque de la provincia de Omasuyos al pareser

de quarenta años casado con Catalina Limachi de

treinta y ocho años tiene por hijos

Acencio de sinco años

Bernardo Vasquez de Cosapa al pareser de quarenta años

casado con Sebastiana Ursula de quarenta años tiene por hijos

Maria de siete años

Rosa de sinco años

\section{$\underline{\text { Viudos originarios con tierras }}$}

Fransisco Vasquez de quarenta y tres años tiene por hija

Esperansa de sinco años

Sebastian Lupa de treinta años tiene por hija

Tomasina de catorze años

Santos Apas de treinta y tres años tiene por hijos

Bernardino de catorse años

Rafael de ocho años

Luis Blanco de quarenta y dos años tiene por hija

Sebastiana de seis años

\section{$\underline{\text { Solteros originarios con tierras }}$}

Carlos Chuquiguanca de dies y ocho años

Fransisco Arias Nina de dies y nuebe años $\quad 19$

Thomas Mamani de veinte y dos años $\quad 22$

$\begin{array}{ll}\text { Pedro Choque de dies y ocho años } & 18\end{array}$

Fransisco Arias de dies y nuebe años $\quad 19$

Martin Guanca de dies y ocho años $\quad 18$

$\begin{array}{ll}\text { Bentura Apas de dies y ocho años } & 18\end{array}$

$\begin{array}{ll}\text { Rafael Cruz de dies y ocho años } & 18\end{array}$ 
$\begin{array}{ll}\text { Pedro Nolasco Sasosa de dies y ocho años } & 18\end{array}$

$\begin{array}{ll}\text { Melchor Villi de veinte años } & 20\end{array}$

Santiago Vasquez de veinte años $\quad 20$

Bernardo Mamani de dies y ocho años $\quad 18$

Diego Vasquez de veinte y vn años $\quad 21$

[Foja51v]

Pedro Fernandes de dies y nuebe años $\quad 19$

Juan Mamani de dies y nuebe años $\quad 19$

$\begin{array}{ll}\text { Miguel Ramos de veinte años } & 20\end{array}$

Theodoro Bolaños de treinta y quatro años $\quad 34$

Nicolas Santos de veinte y quatro años $\quad 24$

Lopez Coria de dies y nuebe años $\quad 19$

$\begin{array}{ll}\text { Pedro Choquemini de dies y ocho años } & 18\end{array}$

\section{Reserbados}

Gaspar Condori de sesenta y un años casado con

Rosa Mamani de sinquenta y sinco años tiene por hijos

Maria Monica de veinte y un años

Geronimo Valencia de setenta y sinco años casado con

Maria Manclla de setenta y tres años

Ignacio Choque (ciego) de veinte y sinco años

\section{$\underline{\text { Viudas }}$}

Flora Quenaya de quarenta y vn años tiene por hijos

Damian Rafael de trese años

Fausta Rafael de ocho años

Lucia de seis años

Maria Peres de treinta años tiene por hijos

Diego Cusi Mamani de quatro años

Ana Cusi Mamani de dies años

Dionicia de siete años

Valentina de sinco años

Andrea Alanoca de sinquenta años

Ana Mamani de sesenta años

Andrea Choque de setenta años

Ana Choque de setenta y sinco años

Andrea Sisa de nobenta años

Antonia Argote de quarenta años tiene por hija a

Petrona Apasa de dos meses

Bartola Calisaya de sesenta años

Bartola Castillo de sesenta años tiene por hija a

Maria Cruza de treinta y sinco años

Bartola Gutierres de nobenta y sinco años

Barbara Sisa de cien años

Isabel Cutipa de sinquenta años tiene por hijos

[Foja52r]

Sebastian Condori de dose años

Fermina Condori de veinte años

Bernarda Condori de quinse años

Paula Cutipa de sinquenta y sinco años

Fransisca Cutipa de sinquenta y ocho años

Maria Cutipa de sesenta años

Catalina Albarado de quarenta y sinco años

Crispina Medina de sesenta años tiene por hija

Rosa Cutipa de veinte y sinco años

Eugenia Limachi de setenta años [sic]

Esperanza Guanca de sinquenta años tiene por hijo

Fransisco Peres de doze años

Esperanza Choque de quarenta años tiene por hijos

Matias de dies años 
08

Estefania de ocho años

Fransisca Valencia de quarenta y tres años tiene por hijos

Pablo Condori de trese años

Amancio Condori de dies años

Ines Condori de doze años

Gregoria Cutipa de sesenta años

Isidora Colque de sesenta y ocho años

Juliana Limachi de ochenta años

Jossefa Mamani de sesenta y tres años

Juana Quenaya Guanca de sesenta años tiene por hija

Maria de veinte y dos años

Maria de veinte años

Maria Mamani de sesenta años tiene por hija

Maria Amanta de quinse años

Maria Flora de sesenta años

Micaela Zuñiga de sinquenta y dos años

Maria Medina de setenta años

Maria Velorio de ochenta años

Micaela Silvestre de veinte y sinco años

Maria Flores de nobenta y sinco años

Prudencia Yugna de quarenta y dos años tiene por hijo

Alejo Blanco de doze años

Andres de tres años

Petrona Sisa de setenta y ocho años

Paula Manclla de treinta y ocho años

\section{[Foja52v]}

Rosa Chino de sinquenta años - tiene por hijos

Jossef de seis años

Marta Guisa de veinte años

Rosa Quenaya de sinquenta y dos años tiene por hija

Ana Humiri de veinte años

Melchora Ramos de quarenta y ocho años tiene por hijos

Diego Limachi de seis años

Paula Sisa de quarenta años tiene por hijo

Fransisco Mamani de nuebe años

Sebastiana Yugna de quarenta y tres años tiene por hijos

Fransisco Quispe de quinse años

Carlos Quispe de trese años

Juana Quispe de onse años

Ana Sisa de sinquenta y nuebe años

Nicolasa Valencia de treinta y nuebe años

Lucia Mamani de sinquenta años - tiene por hijos

Andres Apasa de quatro años

Catalina Apasa de quinse años

Maria Carbajal de veinte años

Bartola Mamani de quarenta y siete años

Maria Choqueguanca de sinquenta y dos años

\section{$\underline{\text { Solteras }}$}

Micaela Yugna de veinte y quatro años tiene por hijos

Gregorio Yugna de vn año

Paula Espejo de veinte y sinco años tiene por hijos

Pedro de siete años

Eusevio de vn año

Lucia Yugna de dies y nuebe años tiene por hija

Rosa de un año

Victoria Yugna de dies y ocho años

Melchora Vara de veinte años

Theodora Tato de treinta años tiene por hijo

Thomas de dos años 


\section{$\underline{\text { Huerfanos }}$}

Pheliciano de nuebe años

Mariano Salvador de catorse años

[Foja53r]

Miguel Cutipa de doze años

Miguel Cusi Mamani de nuebe años

Alberto Albares de dose años

Onorio Guanca de dies años

\section{$\underline{\text { Huerfanas }}$}

Fransisca Inquiltupa de quinse años

Elena de ocho años

Ventura Mamani de ocho años

Dominga Cutipa de dies y seis años

Andrea Yugra de dies y seis años

Victoria Yugra de catorse años

Petrona Vasques de sinco años

Maria Mamani de catorse años

Andrea Velorio de nuebe años

\section{$\underline{\text { Cholos solteros con tierras }}$}

Fernando Tapia de Calacoto al pareser de treinta y tres años

Padron del pueblo de Sora

Originarios casados con tierras

Antonio Rojas de quarenta y vn años casado con

Maria Flora de treinta y seis años tiene por hija a

Gregoria de siete años

Acencio Limachi de veinte y sinco años casado con

Eulalia Vernal de veinte y sinco años tiene por hija

Valentina de un año

Baltazar Alanoca de veinte y tres años casado con

Antonia Chuquiguanca de veinte años tiene por hijo

Marzelo de tres años

Crisostomo Lobera de veinte y dos años casado con

Juana Sarsuri de veinte años tiene por hijos

Jossef de siete años

Lucas de quatro años

Maria de vn año

Nicolas Peres de veinte y seis años casado con

Maria Yugra de veinte y dos años tiene por hijos

\section{[Foja53v]}

Maria de quatro años

Pasquala de vn año

Juan Alanoca Buitron de veinte y sinco años casado con

Paula Manclla de veinte y sinco años tiene por hijos

Marcelo de siete años

Lucia de dos años

Diego Vilca de quarenta y ocho años casado con

Maria Caseres de quarenta años

Silbestre Vilca de veinte y siete años casado con

Petrona Mamani de veinte y dos años tiene por hijo

Domingo de tres años

Lorenzo Vilca de treinta años casado con 
Micaela Carbajal de veinte y ocho años tiene por hijos

Ilario de tres años

Domingo Medina de veinte y quatro años casado con

Cruza Sarsuri de veinte años tiene por hijos

Bartola de seis meses

Salvador Tapia de quarenta y un años casado con

Magdalena Condori de quarenta años

Marcos Limachi de veinte y sinco años casado con

Juana Vara de veinte y dos años tiene por hijos

Domingo de siete años

Bernarda de un año

Agustin Franco de treinta años casado con

Juana Sisa de veinte años tiene por hijo

Acencio de seis años

Fransisco Tapia de veinte y dos años casado con $\quad 22$

Gregoria Mamani de veinte años

Florentino Luque de treinta años casado con

Esperanza Medina de veinte y quatro años tiene por hijos

Tiburcio de seis años

Andrea de un año

Maria Condori de veinte años

Juan Guanca de veinte y dos años casado con

Paula Chino de veinte años $=$ tiene por hijo

Sebastian de seis meses

Lucas Coria de veinte y sinco años casado con 25

Isabel Chuquiguanca de veinte años tiene por hijos

Manuel de tres años

\section{[Foja54r]}

01 Lorenza de vn año

Martin Caseres de quarenta y seis años casado con

Thomasa Limachi de quarenta y sinco años tiene por hijos

Isidora de ocho años

Polonia de sinco años

Juana de un año

Seberino Franco de veinte y ocho años casado con

Maria Alanoca de veinte y siete años tiene por hijos

Marta de sinco años

$01 \quad$ Dominga de un año

Matias Miranda de treinta años casado con

Rosa Quispe de treinta años tiene por hijos

Roque de dos meses

Petrona de sinco años

10 Maria de dies años

Justo Pastor Bolaños de veinte y ocho años casado con $\quad 28$

Maria Vasquez de treinta años

Justo Quispe de treinta y sinco años casado con

Esperanza Choque de treinta y tres años tiene por hijos

\section{$\underline{\text { Solteros originarios con tierras }}$}

Ignacio Medina de dies y nuebe años

Pedro Nolasco Caseres de veinte y vn años $\quad 21$

Nicolas Caseres de dies y ocho años 
$\begin{array}{ll}\text { Pedro Yugra de veinte años } & 20\end{array}$

Cristobal Chino de dies y nuebe años $\quad 19$

$\begin{array}{ll}\text { Cristobal Lobera de veinte años } & 20\end{array}$

$\begin{array}{ll}\text { Domingo Lusa de dies y ocho años } & 18\end{array}$

\section{Reservados}

Juan Espinosa Tapia de sinquenta y vn años casado con

\section{Viudas}

Maria Theresa Castillo de quarenta y siete años tiene

por hijos

Thomas Lusa de catorse años

Micaela Lusa de dies y seis años

Micaela Nina de quarenta años

Cecilia Choque de treinta y ocho años tiene por hijos

Florentino de catorse años

Ilario de ocho años

Maria de seis años

Maria Molina de treinta y ocho años tiene por hijo a

Martin Peres de catorse años

Juana Caseres de sinquenta años tiene por hijos

Miguel Yugra de ocho años

Catalina Alanoca de sesenta años

Lucia Alanoca de sesenta años

Maria Sisa de quarenta años

\section{$\underline{\text { Solteras }}$}

Antonia Ramires de quinse años

Lucia Mamani de dies y siete años

Melchora Choque de veinte años

Maria Zanches de veinte y quatro años

Juana Mamani de veinte años

Maria Choque de dies y seis años

\section{Huerfanos}

Baltazar Choque de doze años

Victorio Santos de ocho años

Isidro Sisa de doze años

Padron del pueblo de Putre originarios casados con tierras

Pablo Mamani de quarenta y vn años casado con

Acencia Guanca de quarenta y vn años tiene por hijos

Jossefa de dies años

Bernarda de ocho años

Marcela de seis meses

Ambrosio Condori de quarenta y vn años casado con

Acencia Guanca Limachi de quarenta y vn años tiene por hijos

Juan Antonio de onse años

[Foja55r]

Bernarda de nuebe años

Romualda de siete años

Acencio Alanoca de quarenta años casado con 
Maria Condori de quarenta años tiene por hijos

Maria de dies y ocho años

Magdalena de dies y seis años

Pasquala de sinco años

Paula de tres años

Polonia de un año

Ambrocio Tiburcio Guanca de veinte y tres años casado con

Paula Chino de veinte y un años tiene por hijos

Thomas de quatro años

Miliano Bernardo Caseres de quarenta y vn años casado con

Maria Sarsuri de quarenta años tiene por hijos

Thomas de trese años

Fransisco de sinco años

Alejo de tres años

Pheliciano de dos años

Fransisca de dies y seis años

Bartolome Apas de quarenta y vn años casado con

Bartola Caseres de quarenta y dos años tiene por hijos

Eugenia de catorse años

Sebastiana de ocho años

Baltazar Lobera de treinta y tres años casado con

Maria Evarista Yugra de treinta años tiene por hijos

Baltazar Espinosa Lobera de vn año

Ana de trese años

Ventura de nuebe años

Baltazar Zanches de quarenta y vn años casado con

Thomasa Lobera de quarenta y dos años tiene por hijos

Blas de dies años

Justo de vn año

Maria de dies y seis años

Lucia de tres años

Basilio Ticona de treinta y vn años casado con 31

Maria Cruz de treinta y sinco años

$\begin{array}{ll}\text { Ignocencio de sinco años } & 05\end{array}$

Agustin de dos años

Valeriano Condori de veinte y ocho años casado con

Maria Choque de veinte y seis años tiene por hijos

Agustin de onse años

Cruz de siete años

[Foja55v]

Manuel de vn año

Acencia de quatro años

Ursula de dos años

Domingo Yugra de treinta y dos años casado con

Juana Sisa de treinta y sinco años tiene por hijos

Thomasina de quinse años

Valentina de siete años

Isidora de quatro años

Fransisco Guanca (viejo) de quarenta y siete años casado

Manuela Marcela Yugra de quarenta y sinco años

tiene por hijos

Sebastian de ocho años $\quad 08$

Casildo de sinco años $\quad 05$

Fransisco de quinse años $\quad 15$

Ana de onse años

Fransisco Guanca de veinte y quatro años (moso) casado con $\quad 24$

Theodora Barra de veinte y dos años tiene por hijos

Marta de seis meses

Fransisco Benabente de treinta y sinco años casado con

Paula Choqueguanca de treinta y sinco años

Fransisco Caseres de veinte y sinco años casado con 
Bernarda Alanoca de treinta años tiene por hijos

Pheliciano de sinco años

Manuel de vn año

Gregorio de siete años

Maria de dos años

Ildefonso Choque de treinta y seis años casado con

Polonia Chino de treinta y sinco años tiene por hijos

Thomas de catorse años

Isidro Guanca de veinte y seis años casado con

Maria Alanoca de veinte y sinco años tiene por hijos

Bernardo de seis meses

Casilda de dos años

Ildefonso Sarsuri de veinte y tres años casado con

Rosa Quibaillo de veinte y seis años tiene por hijos

$00.6 \quad$ Maria de seis meses

Juan Colque de veinte y quatro años casado con

Anastacia Yugra de veinte y dos años tiene por hijos

Demetrio de un año y seis meses

[Foja56r]

08 Paula Yugra de ocho años

Juan Coria de veinte y seis años casado con

$30 \quad$ Juana

Chuquiguanca de treinta años tiene por hijos

Patrona de catorse años

Fransisca Paula de vn año

Julian Medina de veinte y siete años casado con

María Condori de veinte y ocho años tiene por hijos

Pasqual de ocho meses

Juan Yugra de veinte y tres años casado con

Dominga Condori de veinte y dos años y tiene por hijos

Valeciano de quatro años

Seberino de quatro meses

Marcos Quibaillo de treinta y vn años casado con

Paula Caseres de veinte y sinco años tiene por hijos

Sebastian de dies años

Ynnocencio de dies meses

Fabiana de tres años

Miguel Condori de treinta y ocho años casado con

Micaela Nina de treinta años tiene por hijos

Fransisca de seis años

Pablo Luque de treinta y tres años casado con

Josepha Peres de treinta y sinco años tiene por hijos

Casildo de tres años

Eugenia de nuebe años

María de ocho meses

Pasqual Condori de treinta y siete años casado con

Andrea Choque de treinta y siete años tiene por hijos

Agustin de dies y seis años

Maria de onse años

$04 \quad$ Ylaria de quatro años

$00.6 \quad$ Prudencia de seis meses

Sebastian Vara de treinta años casado con

Anastacia Condori de treinta años tiene por hijos

Diego de seis años

Pheliciana de seis meses

Petrona Colque de veinte y sinco años tiene por hijos

Torivio Chino de veinte y dos años casado con

Anastacia Hato de veinte y dos años

Pasqual Vilca de quarenta y vn años casado con 
39

04

01

40

06

30

\section{[Foja56v]}

Ana Quispe de treinta y nuebe años tiene por hijos

Diego de ocho años

Lorenza de quatro años

Fransisca de vn año

Matias Casca de quarenta y vn años casado con

Sebastiana Quispe de quarenta años tiene por hijos

Valeriano de quatro años

Narsiso de dos años

Eugenia de seis años

Anastacia Paca de treinta años tiene por hijos

Gregoria de sinco meses

Thomas Caseres de veinte y dos años casado con

Bernarda Luque de veinte y vn años

Roque Mamani de veinte y tres años casado con 23

Victoria Yugra de treinta y ocho años

Pedro Quibaillo de treinta y vn años casado con Dominga 31

Vara de treinta años tiene por hijos

Luis de nuebe años

Domingo de siete años $\quad 07$

$\begin{array}{ll}\text { Basilio de quatro años } & 04\end{array}$

Rafael de onse años $\quad 11$

María de dos años

$\begin{array}{ll}\text { Juan Carbajal de quarenta y siete años casado con } & 47\end{array}$

Pasquala Ramos de treinta años tiene por hijos

Evaristo de dos años

Paula de dose años

Romualda de seis años

Maria de quatro años

Juan Carbajal de dies y ocho años casado con

Rosa Gutierres de veinte años

Vizente Ramos de quarenta y vn años casado con Ma

ria Mita de quarenta y ocho años tiene por hijos

Florentino de siete años

Agustin Vasquez de quarenta y vn años casado con

Maria Mamuelo de treinta y nuebe años tiene por hijos

Jossef de doze años

Ana Fransisca de dies años

Santusa de vn año

\section{[Foja57r]}

Sebastian Velasquez Venabente de treinta y ocho años casado con Maria del Rosario de treinta y seis años

Bernardo Yugra de veinte y dos años casado con

Isabel Condori de veinte años

Jossef Alanoca de dies y ocho años casado con

Thomasa Mamani de dies y nuebe años

\section{Viudos originarios con tierras}

Fausto Casca de treinta y tres años tiene por hijos

Agustin de trese años

Barbara de siete años

Maria Cruz de dos años

\section{$\underline{\text { Solteros originarios con tierras }}$}

Diego Venabente de quarenta y siete años 
$\begin{array}{ll}\text { Pedro Choque de dies y ocho años } & 18\end{array}$

Pedro Nolasco Caseres de dies y ocho años $\quad 18$

$\begin{array}{ll}\text { Fransisco Molina de veinte y vn años } & 21\end{array}$

$\begin{array}{ll}\text { Fransisco Yugra de dies y ocho años } & 18\end{array}$

$\begin{array}{ll}\text { Justo Lobera de veinte años } & 20\end{array}$

$\begin{array}{ll}\text { Miguel Cuba de veinte años } & 20\end{array}$

$\begin{array}{ll}\text { Nicolas Ticona de veinte y vn años } & 21\end{array}$

$\begin{array}{ll}\text { Silbestre Condori de veinte y dos años } & 22\end{array}$

$\begin{array}{ll}\text { Bartolome Tupiri de dies y ocho años } & 18\end{array}$

Andres Caseres de veinte años $\quad 20$

$\begin{array}{ll}\text { Lorenzo Yugra de treinta años } & 30\end{array}$

$\begin{array}{ll}\text { Ventura Medina de dies y ocho años } & 18\end{array}$

$\begin{array}{ll}\text { Juan Mita de dies y ocho años } & 18\end{array}$

Lorenzo Mita de veinte y vn años $\quad 21$

$\begin{array}{ll}\text { Ylario Ticona de dies y ocho años } & 18\end{array}$

\section{$\underline{\text { Reservados }}$}

Andres Cañipa de sinquenta y vn años casado con

[Foja57v]

Ysidora Paca de treinta y tres años tiene por hijos

Fransisco Paca de dies y seis años (cojo)

Florentino Quibaillo de ocho años $\quad 08$

Miguel Quibaillo de dos años

Maria Quibaillo de dose años

Ysabel Limachi de sinquenta años

60 Acencia Guanca de sesenta años

\section{$\underline{\text { Solteras }}$}

Rosa Mamani de veinte y quatro años tiene por hijo

Lasaro Mamani de dies años

Marta Ticona de dies y seis años

Jossefa Sarsuri de veinte y quatro años

Rosa Alanoca de catorse años

Petrona Paca de dies y nuebe años

Andrea Limachi de veinte años

Bernarda Benabente de dies y nuebe años

Ventura Lobera de dies y seis años

\section{$\underline{\text { Huerfanos }}$}

Pedro Guanca de ocho años

Alberto Guanca de sinco años

Santiago Yugra de dies años

Phelipe Luque de dies años

Fransisco Luque de dies años

$\underline{\text { Huerfanas }}$

Juliana Guanca de tres años

Dionicia de trese años

Fabiana de dos años

Acencia Luque de ocho años

Lucia Dias de dies años

Maria Mamani de ocho años

Petrona Mamani de sinco años 


\section{Cholos casados con tierras}

Julian Valdes mestizo de La Paz casado con Gregoria Quispe originaria de quarenta y sinco años tiene por hijos

Martin de quatro años

Fabian de tres años

[Foja58r]

Maria Gonzales de sesenta y vn años [sic]

Maria Casilda de sesenta y siete años

Jossefa Ticona de sesenta y vn años

Maria Tapia de sesenta y siete años

Esperanza Sisa de setenta y sinco años

Antonia Sisa de sesenta años

Bartola Salvador de sinquenta y dos años

Petrona Luque de sesenta y tres años

Ysabel Choque de sesenta y un años

Ana Guanca de quarenta y tres años tiene por hija

Marta Vedoya de onse años

Esperanza Alanoca de sinquenta años tiene por hijo

Tiburcio Condori de trese años

Dominga Choque de quarenta y ocho años tiene por hija

Maria Ticona de dies y seis años

Rosa Limachi de quarenta años tiene por hijos

Pedro Cuba de trese años

Juana de dies y siete años

Ursula Sisa de sinquenta años tiene por hijos

Marcos Molina de dose años

Romualda de veinte y quatro años

Maria Limachi de sesenta y quatro años tiene por hija

Esperanza Sisa de quarenta años

Fransisca Guanca de setenta años

Paula Luque de quarenta y seis años tiene por hijos

Yldefonso Alanoca de dies años

Dionicio Alanoca de doze años

Rosa Guanca de quinse años

Marta Quibaillo de treinta años tiene por hija

Victoria de tres años

Juana Alanoca de quarenta y tres años tiene por hijos

Maria Paca de ocho años

Paula Paca de siete años

Barbara Paca de tres años

Pasquala Luque de treinta y sinco años tiene por hija

Victoria Condori de nuebe años

Micaela Tapia de setenta y sinco años

\section{[Foja58v]}

Maria Ticona de quarenta y quatro años tiene por hija

Rosa de dies y ocho años

Baltazar Choque de sinquenta y quatro años casado con

Angelina Sisa de sesenta y tres años

Diego Medina de sinquenta y quatro años

Pedro Sarsuri de sinquenta y tres años casado con Fransisca

Inquiloupa de sinquenta y ocho años

Santos Mita de setenta y ocho años tiene por hijos

Ana Mita de veinte y sinco años

Cruz Tupiri de setenta años

Lorenzo Rojas de setenta y tres años casado con Thomasa

\section{$\underline{\text { Viudas }}$}


Ysabel Orcoma de setenta años

Rosa Chuquiguanca de setenta y dos años

Josseffa Guanca de ochenta años

Anastacia Yugra de nobenta años

Juana Yugra de ochenta y sinco años

Juana Flora de nobenta y tres años

Maria Quenaya de sinquenta años tiene por hijos

Laureano de sinco años

Pheliciana Guanca de dies y siete años

Barbara Lobera de sinquenta y un años

Maria Benabente de quarenta y sinco años tiene por hijos

Gregoria de dies y ocho años

Thomasa Yugra de quarenta y ocho años

Maria Sisa de ochenta y nuebe años

Theresa Condori de sesenta y sinco años

Maria Condori de quarenta y dos años tiene por hijos

Diego Yugra de catorse años

Norberta Yugra de sinco años

Pheliciana de dos años

Micaela Condori de sinquenta y quatro años

Maria Yugra de quarenta y siete años tiene por hija

Andrea de doze años

\section{[Foja59r]}

Esperanza de dies y ocho años

Bernarda de quinse años

Ysidora de trese años

\section{Padron del Pueblo de Parinacota}

Originarios casados con tierras

Agustin Calle de treinta y siete años casado con

Manuela Thorres de treinta años tiene por hijos

Juan de seis años

Ylario de quatro años

Santusa de ocho años

Alejandro Flores de veinte y seis años casado con

Polonia Alabe de veinte y tres años tiene por hijos

Romualda de tres años

Acencio Alabe de quarenta y nuebe años casado con

Melchora Contreras de quarenta y ocho años tiene por hijos

Fransisco de catorse años

Lorenzo de onse años

Julian de nuebe años

Pedro de tres años

Alejandro de tres meses

Cristina de siete años

Alberta de sinco años

Maria de ocho años

Ventura Chuquiguanca de treinta y siete años casado tiene por hijos

Alberto de vn año y seis meses

Bartola de quatro años

Bernardo Inuta de veinte y quatro años casado con

Blasa Lopez de veinte y tres años tiene por hijos

Marzela de sinco años

Paula de tres años

Ylaria de seis meses

Domingo Flores de veinte y dos años casado con

Ana Gutierres de veinte años

Enrique Blanco de veinte y siete años casado con 
Maria Choqueguanca de veinte y quatro años tiene por hijos [Foja59v]

Juan de sinco años

Maria de siete años

Victoria de un año

Fransisco Viza de veinte y siete años casado con

Petrona Flores de veinte y quatro años tiene por hijos

Ysabel Gutierres de doze años

Rosa Gutierres de dies años

Fransisco Thorres de veinte y nuebe años casado con

Casilda Quispe de veinte y sinco años tiene por hijos

Fransisco de quatro años

Fransisco de doz años

Jossef de dies años

Gregorio Gutierres de quarenta y quatro años casado con $\quad 44$

Fabiana Carbajal de quarenta y dos años tiene por hijos

Yldefonso de siete años

Severino de sinco años

Fransisco de dos años

Pheliciana de catorse años

Ysidro Gutierres de quarenta y vn años casado con

Josepha Mollo de quarenta y vn años tiene por hijos

Gabriel de quinse años

Crispina de dies y siete años

Maria de doze años

Magdalena de vn mes

Lorenzo Choqueguanca de quarenta y dos años casado con

Margarita Estrada de quarenta y tres años tiene por

hijos

Ysidro de dies años

Fransisco de ocho años

Pheliciana de doze años

Acencia de seis años

Pheliciana de seis meses

Martin Calisaya de quarenta y quatro años casado con

Lorenza Thorres de quarenta y tres años tiene por hijos

Jossef de dies y seis años

Pedro Guanca de veinte y ocho años casado con 28

Lorenza Gutierres de veinte y sinco años tiene por hijos

Luis de quatro años

[Foja60r]

Laureano de seis meses

Pedro Gutierres de veinte y vn años casado con

Maria Flores de dies y nuebe años tiene por hijos

Matias de tres años seis meses

Juan de vn año

Laureano Lopez de veinte y quatro años casado con $\quad 24$

Catalina Humiri de veinte años tiene por hijos

Torivio de dos años

Bartola de quatro años

Valeriano Lopez de veinte y vn años casado con 21

Tomasa Alabe de quinse años

Santiago Blanso de quarenta y siete años casado con

Pasquala Flores de quarenta y sinco años tiene por hijos

Ramon de onse años

Manuela Gomes de veinte años tiene por hijo

Pheliciano de seis meses

Lazaro Ramos de quarenta y vn años casado con 
01

05

Eugenia de un año

Thomas Gutierres de quarenta y vn años casado con

Petrona Agnuta de treinta años tiene por hijos

Cristobal de tres años

Maria de sinco años

Andrea de un año

Fernando Blanco de quarenta y ocho años casado con

Acencia Carbajal de sinquenta años

Laureano Misto de treinta y cinco años casado con

Ursula Carbajal de treinta y dos años tiene por hijos

Augustin de ocho años

Ana de dies años

Petrona de seis años

Dominga de sinco años

Ylaria de seis meses

\section{Viudos originarios con tierras}

Bernardo Thorres de quarenta y siete años tiene por

hijos

Maria de veinte y ocho años

Maria de siete años

[Foja60v]

\section{$\underline{\text { Solteros originarios con tierras }}$}

Marcos Alabe de veinte años

Carlos Choqueguanca de dies y ocho años

Pablo Feliciano de veinte y quatro años

Andres Thorres de veinte y vn años

Antonio Blanco de dies y ocho años

Fausto Gomes de dies y ocho años

Alejo Guanca de veinte y vn años

\section{$\underline{\text { Reservados }}$}

Matheo Maita de setenta años casado con

Pasquala Alabe de quarenta y vn años

Sebastian Lopez de sinquenta y siete años casado con

Maria Esperanza de sinquenta y siete años tiene por hijo a

Juan de tres años

Pablo Choqueguanca de sinquenta y quatro años casado

con Maria Calle de quarenta y siete años tiene por hijos

Pablo de veinte y nuebe años (siego)

Phelipe de ocho años

Sebastiana de catorse años

Romualda de dose años

\section{$\underline{\text { Viudas }}$}

Rosa Ortis de quarenta años tiene por hijos

Pablo Umiri de dies y siete años

Thomas de quinse años

Justa Umiri de dies y ocho años

Petrona de siete años

Maria Monica de veinte años tiene por hijos

Julian Choqueguanca de trese años

Lorenza Vega de sinquenta años

Tomasa Carbajal de quarenta y sinco años tiene por hija 
Maria de veinte y seis años

Andrea Umiri de sinquena años

Catalina Linares de sinquenta y tres años

Petronila Medina de quarenta y siete años

Jossefa Benabente de treinta años: tiene por hijo

Manuel Lopez de onse años

[Foja61r]

Maria Carbajal de treinta y nuebe años tiene por hija

Ysidora Gomes de trese años

Andrea Guanca de quarenta y ocho años tiene por hija

Ysabel Blanco de dies y ocho años

Sebastiana Estrada de sinquenta años tiene por hija

Petrona Carbajal de veinte y quatro años

Maria Inquiltupa de treinta y quatro años tiene por hijos

Miguel Guanca de seis años

Antonia de nuebe años

Juana Umiri de sesenta años

Maria Inquiltupa de setenta años

Maria Choque de treinta años

Lucia Apasa de quarenta años

Ana Choque de quarenta y siete años

\section{Solteras}

Maria Gutierres de quarenta y seis años tiene por hijos

Maria Blanco de trese años

Acencia de ocho años

Paula Umiri de dies y seis años

Rosa Gutierres de dies y seis años

$\underline{\text { Huerfanos }}$

Jossef Espinosa Inquiltupa de trese años

\section{$\underline{\text { Huerfanas }}$}

Maria Flora Inquiltupa de siete años

\section{Originarios del Asiento de Choquelimpe: mineral con tierras}

Nicolas Mango de quarenta y vn años casado con

Jossefa Lopez de quarenta y ocho años tiene por hija

Sebastiana de veinte años

Augustin Mango de treinta y dos años casado con

Catalina Chambi de treinta y dos años tiene por hijos

Acencio de siete años

\section{[Foja61v]}

Matias de quatro años

Cipriano Mamani de treinta y nuebe años casado con

Juana Flores de treinta y ocho años = tiene por hija a

Dominga de dies y siete años

Pasqual Loaisa de veinte y seis años casado con

Maria Torres de veinte y quatro años tiene por hijos

Pablo de quatro años 


\section{$\underline{\text { Viudos originarios con tierras }}$}

Pedro Peres de quarenta y quatro años tiene por hijos 44

Cruz Peres de catorse años

Alejo de tres años

Ana de veinte y dos años

Maria de ocho años

Maria de dies y seis años

\section{$\underline{\text { Solteros originarios con tierras }}$}

Bernardo Umiri de dies y nuebe años

\section{Originario reservado}

Sebastian Umiri de veinte y vn años tullido

Forasteros casados con forateras [sic]

Lorenzo Medina de Carangas al pareser de quarenta y

\section{$\underline{\text { Solteros Forasteros sin tierras }}$}

Xavier Choque de Carangas al pareser de quarenta años

$\underline{\text { Viudas }}$

Catalina Condori de ochenta años

Barbara Mango de quarenta años tiene por hijos

Ylario de ocho años

Sebastian de tres años

Maria Santos de quarenta años tiene por hijos

Vizente Quispe de doze años

Ventura Agnocuti de dies y ocho años

\section{[Foja62r]}

Maria Mollo de sinquenta y siete años tiene por hijo

Gervasio Humiri de dies años

Santusa Condori de treinta y quatro años tiene por hijos

Acencia Mamani de dies y seis años

Juliana Mamani de catorse años

Maria Mamani de siete años

Esperanza Sentellas de sinquenta y siete años

\section{Padron del Aillo de Caquena \\ $\underline{\text { Originarios casados con tierras }}$}

Agustin Carbajal de veinte y quatro años casado con

Maria Alanoca de veinte y quatro años tiene por hija

Acencia de ocho años

Esteban Condori de veinte y seis años casado con

Paula Ynquiltupa de veinte años

Pedro Yugra de veinte y siete años casado con

Acencia Romero de veinte y quatro años tiene por hijos

Miguel de seis años

Dionicio de dos años

Maria de quatro años

Miguel Mita de veinte y dos años casado con

Angelina Venabente de veinte años tiene por hijos

Valeriano de tres años

Sebastiana de vn año

Pasqual Mita de quarenta y quatro años casado con 
43

12

Maria Elena de quarenta y tres años tiene por hijos

Florentino de tres años

Rosa de doze años

Catalina de dies años

Sebastian Chambí de quarenta y dos años casado con

Maria Vasquez de quarenta años tiene por hijos

Juan de doze años

Simon Yugra de treinta y tres años casado con

Petrona Ana de treinta años tiene por hijos

Jossef de seis años

Cecilia de dos años

Ermenegilda de quatro años

Phelipe Yugra de veinte y dos años casado con Andrea

[Foja62v]

Vasquaces de veinte años tiene por hija

Marta de vn año

Fransisco Vasquez de dies y ocho años casado con

Juana Yugra de veinte y dos años tiene por hijos

Lorenzo de quatro meses

Guillermo Choque de treinta y un años casado con

Pasquala Inquiltupa de veinte y sinco años tiene por hijos

Jossef de sinco años

05

Marcos de tres años

03

Manuel de un año

Manuel Choque de veinte y seis años casado con

Fransisca Mita de veinte y quatro años tiene por hijos

Florentino de ocho años

Eugenia de sinco años

Basilia de dos años

Tiburcio Choque de dies y nuebe años casado con

Dominga Choqueguanca de dies y ocho años tiene por hija

Petrona de vn año

Andres Yugra de veinte y siete años casado con

Catalina Losa de veinte y quatro años tiene por hijos

Baltazar Yugra de quatro años

Ygnacio de vn mes

Jossefa de seis años

Antonia Coria de dies y nuebe años tiene por hija a

Faustina de dos meses

Diego Mita de treinta y siete años casado con

Catalina Lopez de veinte y seis años tiene por hijos

Cipriano de seis años

Yldefonso de quatro años

\section{Forasteros casados con originarias con tierras}

Xavier Tupa de Carangas al pareser de veinte y dos años

\section{$\underline{\text { Solteros originarios con tierras }}$}

Ylario Chambi de dies y nuebe años

\section{[Foja63r]}

Tiburcio Venabente de dies y ocho años $\quad 18$

$\begin{array}{ll}\text { Pedro Ramos de veinte y tres años } & 23\end{array}$

Baltazar Carbajal de dies y nuebe años $\quad 19$

Nicolas Mita de dies y nuebe años $\quad 19$

$\begin{array}{ll}\text { Guillermo Inquiltupa } & 33\end{array}$

$\begin{array}{ll}\text { Acencio Inquiltupa } & 28\end{array}$ 


\section{$\underline{\text { Reservados }}$}

Bernardo Ramos de sesenta y tres años casado con

Ana Sisa de sinquenta años

Andres Villalobos de sinquenta y vn años casado

con Ana Yugra de quarenta y nuebe años tiene por hija

Manuel de tres años

Augustin Yugra de sinquenta y quatro años casado con

Esperanza Sisa de sinquenta años tiene por hijos

18 Dionicia Yugra de dies y ocho años

Pasqual Ynquiltupa de sinquenta y quatro años casado con

Barbara Mamani de quarenta y ocho años tiene por hijos

Miguel de dies años

10

Narsiso de dos años

Agustin Alanoca de sinquenta años casado con

Maria Lopez de sinquenta y tres años tiene por hija

Maria de veinte y quatro años

Diego Colque de sesenta y quatro años tiene por hijo

Santiago de dose años

Fransisco Inquiltupa de setenta y tres años

$\underline{\text { Viudas }}$

Maria Cruz de ochenta años

Pasquala Colque de quarenta y sinco años tiene por hijos

Fransisco Yugra de seis años

Juana Inquiltupa de dies y seis años

Juana Sisa de dies y siete años

Manuela Guanca de veinte y ocho años tiene por hijo

Antonio Alanoca de un año y seis meses

\section{$\underline{\text { Solteras }}$}

Bartola Inquiltupa de dies y seis años

Ysidora Choque de dies y ocho años

[Foja63v]

\section{Huerfanos}

Santos Losa de trese años

Ylario Yugra de nuebe años

Antonio Alanoca de vn año

01

Bernardo Inquiltupa de siete años

07

Faustino Inquiltupa de onse años

\section{$\underline{\text { Solteros originarios ausentes }}$}

Antonio Lupistaca de Pachama de veinte y seis años Joseph Ermenegildo de Pachama de veinte y quatro años Clemente Atana de Guallatiri de dies y nuebe años

En la forma y manera dicha se concluyo la revicita y numeracion de los yndios de este repartimiento y doctrina de Codpa en los altos de dicha ciudad de Arica según y como ba declarado estando presentes yo el dicho Juez revicitador Don Demetrio Egan del orden de Santiago el Doctor Don Diego Zaconeta y Ramires cura y vicario propietario de ella el defensor de real hazienda y demas ministros de ella El Casique governador Don Diego Felipe Cañipa los principales y alcaldes y el protector de ellos Don Juan Jossef Lopez de Santana quienes confesaron y juraron por Dios nuestro Señor y a una señal de cruz según forma de dicho de que a su saber y entender se ha hecho la dicha revicita con toda legalidad verdad y Justicia y que no ha avido ocultacion de ningunos yndios ni muchachos y que en esta virtud no tienen que pedir ni alegar a onor ni en ningun tiempo por no averse hecho ningun agravio a los yndios assi en dicha revicita como en coza alguna sin que haya 
Resumen general

Auto

Respuesta

Proveido avido dolo, ni engaño y lo firmaron conmigo y los testigos con quienes actuo a falta de escrivano / foja 64r/ publico y real $=$ a dies y ocho dias del mes de

nobiembre de mil setecientos setenta y tres años=Demetrio Egan = Doctor Diego de Zaconeta Ramires Juan Estevan de Viscarra = Juan Joseph Lopes de Santana = Bernardo de Vilanoba = Diego Felipe Cañipa $=$ Rafael Bamondes $=$ Interprete Joseph Sinforiano Ximenes $=$ testigo Juan de Velasco y Vrdanibia = testigo Gregorio de Lavaien $=$ resumen general $=$ de los tributarios y demas personas que se hallaron en este repartimiento y doctrina de Cotpa: en la revicita y numeracion de indios que se acaba dicha ser por mi Don Demetrio Egan del orden de Santiago theniente coronel de los reales exercitos corregidor y justicia maior de la ciudad de Arica y su Provincia y revicitador por especial comicion del real y superior gobierno de estos reinos con asistencia de los ministros que la firmaron con arreglo a la instrucción metodica y superior despacho de su excelencia la que recopilada es en la forma y manera siguiente $=$

Primeramente se hallaron y numeraron por tribu tarios existentes setecientos setenta y quatro hom bres

Tambien se numeraron por impedidos de poder trabajar

y por tener y pasar de sinquenta años nobenta y

seis personas

Tambien se empadronaron setecientos ochenta y ocho mu

chachos por no llegar a los dies y ocho años

Tambien se numeraron y empadronaron mil nobecientos

veinte mujeres de todas las edades y clases

de suerte que se han numerado y empadronado en

dicha revicita tres mil quinientas setenta y ocho personas ${ }^{1}$ como aparece de ambos sexos, edades y estados /foja64v/ a que me refiero y constando ser el numero de tributarios setecientos setenta y nuebe se rebajan de ello y veinte hombres por presisos y nesesarios para la recaudacion de los reales tributos y servicio de Iglecia y asi quedan por tributarios existentes setecientos sinquenta y nuebe en cuya virtud y de no resultar agravio alguno en ella contra el comun de dicho repartimiento la doi por conclusa y firmo en este aillo de Caquena termino de dicha doctrina a dies y ocho dias del mes de nobiembre de mil setecientos setenta y tres años, actuando con testigos a falta de escrivano publico y real $=$ Demetrio Egan $=$ testigo Miguel de

Murgnia = testigo Juan de Velasco y Vrdanibia en el aillo de Caquena termino de la doctrina de Cotpa altos de Arica en dies y ocho dias del mes de nobiembre de mil setecientos setenta y tres años; Yo Don Demetrio Egan del orden de Santiago, theniente coronel de los reales exercitos de su magestad corregidor y justicia maior de la ciudad de Arica y su provincia y juez revicitador en ella por especial comicion del real y superior govierno de estos reinos: aviendo visto estos autos y patrones de revicita del repartimiento de Cotpa y sus anexos mando se de traslado al protector de los naturales Don Juan Joseph Lopes de Santana y a don Diego Felipe Cañipa su governador para que en el termino de seis dias vean los padrones y digan lo que a su dicho combenga. Así lo proveo mando y firmo, actuando con testigos a falta del escrivano publico y real y se comete al Alguacil mayor de revicita Don Bernardo Vilanoba $=$ Demetrio Egan $=$ testigo Juan de Velasco y Vrdanibia $=$ testigo Gregorio de Lavasier = en el aillo de Caquena a dies y ocho dias del mes de nobiembre de mil setecientos setenta y tres años, Yo Don Bernardo Vilanoba alguacil mayor de /foja65r/ revicita en virtud del auto antecedente ley notifique en su saber su contenido al protector de

naturales Don Juan Joseph Lopes de Santana y al governador Don Diego Felipe Cañipa en sus personas que lo oyeron y entendieron en su persona lo que certifico y lo firmaron conmigo $=$ Bernardo Vilanoba $=$ Juan Joseph Lopes de Santana = Diego Felipe Cañipa Señor General y jues de revicita $=$ el protector de naturales de esta provincia de Arica Juan Joseph Lopes de Santana y el governador casique principal de la doctrina de Cotpa don Diego Felipe Cañipa respondiendo al traslado que sirbio vuestra merced darnos de la revicita y numeracion de indios de ella, reconocemos se ha actuado y finalisado con toda legalidad en nuestra presencia sin agravio de los indios en comun ni particular por lo que no tenemos reparo que poner a ella en cuya atencion la damos por conclusa y pedimos se remita a dicho real superior gobierno de estos reinos para que la apruebe y confirme y se despache la retasa acostumbrada dejando mi derecho a salvo por justificar con instrumentos la aucencia de varios indios forasteros, que se han ausentado despues de la revicita por todo lo qual $=$ A vuestra merced pedimos y supli

camos asi lo provea y mande por ser de justicia y para ello Juan Joseph

Lopes de Santana $=$ Diego Felipe Cañipa $=$ Caquena y Noviembre veinte y quatro de mil setecientos setenta y tres años = vista la aprobación de la revicita por el Casique Governador don Diego Felipe Cañipa y el protector de los naturales /foja65v/ mando que se una a los autos y se remitan al real 
Auto

y superior govierno de estos reinos como lo piden y así lo proveo, mando y firmo, yo el jues de revicita actuando con testigos a falta de escrivano publico y real Demetrio Egan = testigo Miguel de Murgnia testigo Juan de

Velasco y Vrdanibia = en el aillo de caquena termino de la doctrina de Cotpa altos de Arica en dies y ocho dias del mes de nobiembre de mil

setecientos setenta y tres años; Yo Don Demetrio Egan del orden de Santiago, theniente coronel de los reales ejercitos corregidor y justicia mayor dela ciudad de Arica y su provincia y jues revicitador por especial comicion del real superior govierno de estos reinos digo, que por quanto en la instruccion metodica al capitulo veinte y seis se me ordena aberigue los bienes o ventas de comunidad que aya en cada repartimiento y que esta rason la aya de dar el cura parroco de ella y el casique governador en su virtud debo mandar y mando se libre el exorto correspondiente al señor cura doctrinero de la de Cotpa doctor Don Diego Ramirez de Saconeta con insercion de dicho capitulo para que su vista exponga lo que previene y que al casique governador Don Diego Felipe Cañipa se le notifique de rason de los bienes que go a su comunidad así lo proveo mando y firmo actuando con testigos a falta del escrivano publico y real y se concede al alguasil maior de revicita Don Bernardo de Vilanoba $=$ Demetrio Egan testigo Juan de Velasco y Vrdanibia = testigo Gregorio de Lavayen en el pueblo y aillo de Caqueña dicho mes y año /foja66r/Yo el alguacil maior de revicita notifique e hise saber el auto que antecede al governador don Diego Felipe Cañipa en su persona que lo oyo y lo entendió, lo que certifico y lo firmó conmigo $=$

Respuesta Bernardo de Vilanoba = Diego Felipe Cañipa = en dicho ayllo dicho dia mes y año dichos el casique governador de la doctrina de Cotpa altos de arica don Diego felipe Cañipa en virtud del auto y notificasion antecedente dijo que el

comun de este repartimiento ni tiene caja de comunidad ni renta alguna que solo se mantienen en las tierras de su repartimiento y que no ha llegado a su noticia desde la revicita pasada ayan tenido cosa alguna en comun lo que juro a Dios nuestro señor ser cierto y lo firmo conmigo lo que sertifico $=$ Bernardo de Vilanoba $=$ Diego Felipe Cañipa $=$ rason de las tierras que tiene el comun de indios del repartimiento de Cotpa $=$ La cabesa de este repartimiento y Pueblo nombrado San Martin de Cotpa tiene sus tierras $=$ El pueblo de Pachica tiene tierras de reparto $=$ El Pueblo de Esquiña tiene sus tierras = El Pueblo de Timar tiene sus tierras = el pueblo de Tignamar tiene sus tierras y pastos en la cordillera = el pueblo de Sacsamar no tiene tierras y las que siembran estos indios son arrendadas = el pueblo de Belen tiene sus tierras y pastos en la cordillera; las tierras en el pago de Poconchile cuyo comun está desposeido de un pedaso por Casildo Contreras = el pueblo de Pachama tiene sus tierras y tanbien posee en el pago Ocaguataya = el pueblo de Socoroma tiene tierras en su distrito y tambien en el valle de Sora = el pueblo de Putre tiene tierras y pastos /foja66v/ y tambien tierras en dicho valle de Sora $=$ La estancia de Caquena tiene tierras y pastos = Parinacota tiene tierras y pastos $=$ Guallatire tiene tierras y pastos. El pueblo de Livilca tiene sus tierras. El pueblo de Umagata tiene sus tierras y tambien en la quebrada de Azapa de las quales se halla desposeido por los cornejos y tambien tiene tierras en el pago de Vilavila = Tacna y Marso onse de mil setecientos setenta

Exorto $=\quad$ y quatro años. Diego Felipe Cañipa $=$ Don Demetrio Egan del orden de Santiago theniente coronel de los reales ejercitos de su magestad (que dios guarde) corregidor y justicia mayor de la ciudad de Arica y su provincia y jues de revicita por especial comicion del real y superior govierno de estos reinos = Al señor doctor don Diego de Zaconeta y Ramires cura y vicario de la doctrina de Cotpa altos de Arica, hago saber como aviendo concluido la revicita y numeracion de indios de esta doctrina para su conclusion y mandar se me averigue los bienes o rentas que la comunidad de dicha doctrina tenga y que esta rason las deban dar los curas y governadores de ella he resuelto proveer el auto para quien su inteligencia y del capitulo sitado de la

Auto $=\quad$ rason que se pide el que sacado a la letra es del thenor siguiente $=$ en el aillo de Caquena termino de la doctrina de Cotpa altos de Arica en dies y ocho dias del mes de nobiembre de mil setecientos setenta y tres años yo Don Demetrio Egan del orden de Santiago theniente coronel de los reales exercitos corregidor y justicia mayor de la ciudad de Arica y su provincia y jues revicitador por especial comicion del real y superior govierno de estos reinos: digo que por quanto en la instruccion metodica al capitulo 26

/foja67r/ se me ordena aberigue los bienes o rentas de comunidad que aya en cada repartimiento y que esta rason la ayan de dar el cura parroco de ella y el casique governador en su virtud debo mandar y mando se libre el exorto correspondiente al señor cura doctrinero de la de Cotpa doctor Don Diego Ramires de Zaconeta con insercion de dicho capitulo para que en su vista esponga lo que previene y que al casique governador don Diego Felipe Cañipa se le notifique de rason de los bienes que gosa su comunidad asi lo proveo mando y firmo actuando con testigos a falta de escrivano publico y real $=$ y se comete al alguacil mayor de revicita don Bernardo de Vilanoba $=$ 
desición

respuesta

Peticion

proveido

Certificacion
Lavayen = que se averiguen los bienes o rentas de comunidad que tiene los indios de cada repartimiento especificando con toda claridad y distincion a cuyo fin los manifestaran los curas y casiques y esta rason se pondra al pie de la revicita del que concluida en el todo de la provincia se despacharan sus autos originales al superior govierno acompañados del respectivo informe jurado dejandose testimonio autorisado de la revisita de cada repartimiento en su correspondiente caja de comunidad y de no haverla en el archivo de la provincia para el govierno de los corregidores que la sirbieren inter no se

efectua /foja67v/ nueba numeracion = en cuya conformidad a vuestra merced señor vicario jues eclesiastico de la doctrina de Cotpa en nombre de su magestad exorto y requiero y de la mia pido y encargo que vista esta mi carta se sirba testificar lo que en dicho auto y capitulo se previene que en haserlo asi cumplira vuestra merced con las obligaciones de su cargo, quedando al tanto siempre que las suyas vea justicia mediante que es fecho en esta dicha doctrina de Cotpa y aillo de Caquena a dies y ocho dias del mes de nobiembre de mil setecientos setenta y tres años y lo firme actuando con testigos a falta del escrivano publico y real =y se comete al alguacil maior de revicita don Bernardo de Vilanoba $=$ Demetrio Egan = testigo Juan de

Velasco y Vrdanibia testigo Gregorio de Lavaien = el doctor Don Diego Saconeta Ramires cura propio vicario y jues eclesiastico del beneficio de Codpa, y su jurisdiccion comisario subdelegado de la santa cruzada y examinador sinodal de este obispado respondiendo al exorto que precede librado por el señor general Don Demetrio Egan del orden de Santiago teniente coronel de los reales exercitos corregidor y justicia mayor por su magestad de la ciudad de Arica y su provincia dijo que en los muchos años que ejerse el empleo de cura de dicho beneficio no sabe ni ha oido decir que aia ramo alguno perteneciente a caja de comunidad en la referida doctrina y que /foja68r/ esto es lo que certifica en quanto pueda que es fechado en dicho pueblo en dies del mes de Disiembre de mil setecientos setenta y tres años actuando ante mi con testigos a falta de notario eclesiastico = Don Diego de Zaconeta Ramires = Pedro de Arco = Martin Garcia = Don Diego Felipe de Cañipa casique y governador de esta jurisdiccion de los altos paresco ante vuestra merced en debida forma y digo que estando para concluir la numeracion de indios desta dicha jurisdiccion el señor general Don Demetrio Egan corregidor y justicia maior de esta provincia me ordena le entregue fe de todos los muertos y de los que han nacido desde el año en que se concluyo la ultima numeracion que fue el año de mil setecientos sinquenta y sinco por lo que ocurro a la Piedad de vuestra merced para que me de certificasion asi de los que han muerto como de los que han nacido desde el referido año por lo qual $=$ A vuestra merced pido y suplico se sirba haser en todo como llebo pedido en que recibire merced y justicia y en lo

necesario don $=$ Diego Felipe Cañipa $=$ Cotpa, y enero dies de mil setecientos setenta y quatro $=$ por presentada y vista por su merced dijo que respecto de ser basta la feligrecia de este beneficio de los altos sera necesario trasuntar muchos centenares de partidas y que se contienen en el espacio de dies y ocho años que demandan un espacio largo de tiempo y asi mismo un exesibo gasto /foja68v/ porque aunque dicho señor vicario exibiese dichas partidas graciosamente, como lo hase con todos los que las necesitan, pero el amanuense necesitaria una satisfaccion grande, para un volumen de tanto cuerpo como el que compondrían dichas partidas por lo que le ha parecido conbeniente bolver a entregar los libros de partidas para que por ellos arregle este tropieso el señor Jues revicitador, con la adbertencias de que muchas partidas de entierros no se hallaran en dichos libros por que mueren muchos ya en la tierra donde continuan sus viajes, ya en los valles y otros lugares de la provincia donde salen a poner sus sementeras: asi lo probe y mande y firme con testigos a falta de notario eclesiastico $=$ doctor Diego de Saconeta Ramires $=$ Martin Joseph de Sosa =

Pedro Ario = Muertos del pueblo de Cotpa = certifico Yo el Doctor Don Diego de Zaconeta Ramires cura propio vicario y jues eclesiastico del beneficio de Cotpa, quien los libros de partidas de entierros desta jurisdiccion se hallan las partidas que se iran zitando $=$ Martin Sarabia se hallo muerto en dicho libro a f 13 a la buelta $=$

Andres Osnayo se hallo muerto en un libro forrado en pergamino blanco a f $13=$ Carlos Quirquincha se hallo muerto en un libro forrado en badana colorada a f $15=$ Agustin Garcia en dicho libro se hallo muerto a f $19=$ Agustin se halló muerto en un libro forrado en pargamino blanco a f 25 = Gregorio Caqueo se hallo muerto en dicho libro a f $125=$

Jasinto Mauricio se hallo muerto en un libro forrado en badana colorada a foja 15 /foja69r/ Juan Alabe se halló muerto en un libro forrado en pergamino blanco a f $25=$ Jasinto Vasquez se hallo muerto en dicho libro a f $129=$

Gregorio Garcia se hallo muerto en dicho libro a f 129.

Fransisco Ramires se hallo muerto en dicho libro a f $130=$ Acencio Vilca se hallo muerto en un libro forrado en badana colorida a f 23

Joseph Pacheco se hallo muerto en un libro forrado en pergamino blanco a f 30 a la buelta $=$ 
Santos García se hallo muerto en dicho libro a f $132=$

Lucas Alabe se hallo muerto en dicho libro a f $132=$

Ermenegildo Ramires se hallo muerto en un libro forrado en

pergamino blanco a f 132 a la buelta $=$

Muertos del pueblo de Esquiña = certifico yo el Doctor Don Diego

Saconeta Ramires cura propio Vicario y jues eclesiastico del beneficio de Cotpa que en los libros de partidas de entierros de esta jurisdiccion se hallan las partidas que se iran zitando =

Pasqual Mamani se hallo muerto en un libro forrado en badana blanca a f 32 a la buelta $=$

Diego Condori se halla muerto en un libro forrado en pergamino blanco a f 232 a la buelta $=$

Gervacio Mamani en dicho libro se hallo muerto a f 235.

Silvestre Orosco se hallo muerto en dicho libro a f 235 buelta $=$

Mateo Amaro en dicho libro se hallo muerto a f 200 a la buelta =

Agustin Mamani se hallo muerto en dicho libro a f $253=$

Pedro Choque en dicho libro se hallo muerto a f 258

Vizente Choque en dicho libro a f 271

Martin Gonzales en dicho libro se hallo muerto a f 302

Lucas Mallo en dicho libro se hallo muerto a f 303

Gregorio Lopes se hallo muerto en dicho libro a f $325=$

Agustín Mamani se halló muerto en dicho libro a f 329 buelta

/foja69v/ Muertos del pueblo de Pachica = certifico yo el doctor Don Diego de Zaconeta Ramires cura propio vicario y jues eclesisatico del beneficio de Cotpa que en varios libros de partidas de entierros de esta jurisdiccion se hallan las partidas que se iran zitando $=$

Antonio Peña se hallo muerto en un libro forrado en badana colorada a f 234, Bernardo Gonzales se hallo muerto en dicho libro a f 233

Eugenio Sarate en dicho libro se hallo muerto a f 234 buelta

Raimundo Gonzales en dicho libro se halla muerto a f 235

Andres Mollo en dicho libro se hallo muerto a f 241

Pasqual Guarachi en dicho libro se hallo muerto a f 241

Antonio Asango en dicho libro se hallo muerto a f 24

Estevan Flores en dicho libro se hallo muerto a f 255

Juan Santos Tumbe en dicho libro se hallo muerto a f 258 buelta

Ignacio Gonzales en dicho libro se hallo muerto a f 25 buelta

Gregorio Cailaco en dicho libro se hallo muerto a f 266

Santos Garcia en dicho libro se hallo muerto a f 266

Juan Choquema en dicho libro se hallo muerto a f 276 buelta

Andres Caqueo en dicho libro se hallo muerto a f 276

Nicolas Lopes en dicho libro se hallo muerto a f 276 buelta

Lucas Aguilar en dicho libro se hallo muerto a f 276 buelta

Lorenso Aguilar en dicho libro se hallo muerto a f 277

Acencio Aguilar en dicho libro se hallo muerto a f 321

Martin Cailaco en dicho libro se hallo muerto a a f 321

Dionicio Guarachi en dicho libro se hallo muerto a f 325 buelta

timar $=$ Certifico yo el Doctor Don Diego Zaconeta Ramires cura propio y jues eclesiastico del

beneficio de Cotpa que en varios libros de partidas de entierros de esta jurisdiccion se hallan las partidas que se iran zitando

Tignamar Melchor Solano en un libro de partidas forrado en Badana colorada se hallo muerto a f $25=$ Pedro Santos Mamani en dicho libro se hallo muerto a foxas 233

/foja70r/ Antonio Mamani en dicho libro se hallo muerto a f 236 buelta

Gregorio Valero en dicho libro se hallo muerto a f 268

Timar Pedro Balle en un libro forrado en badana colorada se hallo muerto a f 256 Melchor Buitron en dicho libro se hallo muerto a f 259

Ambrocio Mamani en dicho libro se hallo muerto a f $255=$

Santos Laime en dicho libro se hallo muerto a f 320 buelta

Martín husba en dicho libro se hallo muerto a f 24.

Sacsama $=$ certifico yo el doctor Don Diego Saconeta Ramires cura propio vicario y jues

eclesiastico del beneficio de Cotpa que en varios libros de partidas de entierros de esta

jurisdiccion se hallan las partidas que se iran zitando $=$

Sebastian Veles en un libro forrado en badana colorada se hallo muerto a f $207=$

Pasqual Quiros en dicho libro se hallo muerto a f 247

Felipe Mamani en dicho libro se hallo muerto a f 254 buelta

Joseph Mamani en dicho libro se hallo muerto a f 256 buelta 
Tarque en dicho libro se hallo muerto a f 298 buelta

Belen $=$ Certifico yo el doctor don Diego de Zaconeta Ramires cura mayor propio vicario y jues eclesiastico del beneficio de Cotpa que en varios libros de partidas de entierros de esta jurisdiccion se hallan las partidas que se iran poniendo $=$ Bartholome guanca en otro libro forrado en badana colorada se hallo muerto a f 221 a la buelta $=$ Juan Tarque en dicho libro se hallo muerto a f 223 Joseph Cutipa en dicho libro se hallo muerto a f 225

Sebastian Larba en dicho libro se hallo muerto a f 225

Joseph Larba en un libro forrado en badana colorada se hallo muerto a f 225.

Ramos Mamani en dicho libro se hallo muerto a f 234 buelta.

Nicolas Ramos en dicho libro se hallo muerto a f 239.

Joseph Vasquez en dicho libro se /foja70v/ hallo muerto a f $239=$

Joseph Larba en dicho libro se hallo muerto a f $239=$

Francisco Larba en dicho libro se hallo muerto a f 239

Pedro Cusi se hallo muerto en dicho libro a foxa 24

Miliano Sebastian en dicho libro se hallo muerto a f 266 buelta

Diego Nina en dicho libro se hallo muerto a foja 269 buelta

Agustin Condori en dicho libro se hallo muerto a f 269 buelta

Severino Larba en dicho libro se hallo muerto a f $299=$

Pedro Agnocuti en dicho libro se hallo muerto a foxas 327

Pachama $=$ certifico yo el doctor don Diego de Zaconeta Ramires, cura propio vicario y jues

eclesiastico del beneficio de Cotpa, que en varios libros de partidas de entierros de esta jurisdiccion se hallan las partidas que se iran zitando $=$

Pablo Vasquez en un libro forrado en badana colorada se hallo muerto a f 228

Juan Chura en dicho libro se hallo muerto a f 228

Pedro Churra en dicho libro se hallo muerto a f 228 buelta

Francisco Guarachi en dicho libro se hallo muerto a f 243

Manuel Vara en dicho libro se hallo muerto a f 263

Bartholome Vara en dicho libro se hallo muerto a f 261

$\underline{\text { Socoroma }}=$ Certifico yo el doctor Don Diego de Zaconeta Ramires cura propio vicario y jues eclesiastico del beneficio de Cotpa que en varios libros de partidas de entierros de esta

jurisdiccion se hallan las partidas que se iran zitando $=$

Simon Mamani se hallo en otro libro muerto a f 227.

Bernardo Mamani en dicho libro se hallo muerto a f 230

Pablo Gutierres en dicho libro se hallo muerto a f $237=$

Marcos Castillo en dicho libro se hallo muerto a f $238=$

Florentino Ato en dicho libro se hallo muerto a f 238.

Ramos Mamani en dicho libro se hallo muerto a f 238

Agustin Albarado en dicho libro se hallo muerto a f 238.

Patricio Fernandez en dicho libro se hallo muerto a 247

Feliciano Manilla en dicho libro se hallo muerto a f 251

Florentino Valencia en dicho libro se hallo muerto a f 251 buelta $=$

Theodoro Condori en dicho libro se hallo muerto a f $260=$

Francisco /foja71r/ Cafaci en dicho libro se hallo muerto a f [manuscrito ilegible] Ato en dicho libro se hallo muerto a f 283

Bernardo Carrasco en dicho libro se hallo a f 268

Juan Guanca en dicho libro se hallo muerto a f 294

Benito Guanca en dicho libro se hallo muerto a f 295 buelta.

Juan Mamani en dicho libro se hallo muerto a f 296.

Gregorio Cusi Mamani en dicho libro se hallo muerto a f 313

Manuel Quispe en dicho libro se hallo muerto a f 312

Hilerio Umiri en dicho libro se hallo muerto a f 325

Baltasar Cusi Mamani en dicho libro se hallo muerto a

foxas $330=$

Hilario Mamani en dicho libro se hallo muerto a f 330 buelta $=$

Lucas Guanca en dicho libro se hallo muerto a f 335 buelta $=$

Sora. Certifico yo el doctor Don Diego de Zaconeta Ramires cura propio y vicario jues eclesiastico del beneficio de Cotpa que en varios libros de partidas de entierros de esta jurisdiccion se hallan las partidas que se iran sitando 
Simon Limachi se hallo muerto en un libro forrado en pergamino blanco a f 217 a la buelta $=$ Juan Luque en dicho libro se hallo muerto a f 217 buelta Ildefonso Limachi en dicho libro se hallo muerto a f 231 Joseph Mamani en dicho libro se hallo muerto a f 237 Faustino Alanoca en dicho libro se hallo muerto a f 237 Ildefonso Vera de Putre en dicho libro se hallo muerto a f 243. Andres Mamani en dicho libro se hallo muerto a f 252 Felipe Nieto en dicho libro se hallo muerto a f 260 buelta Silvestre Alanoca en dicho libro se hallo muerto a f f 267 Andres Mamani en dicho libro se hallo muerto a f 301 Pasqual Choque en dicho libro se hallo muerto a f 301 otro Pasqual Choque en dicho libro se hallo muerto a f 313 $\underline{\text { Putre }}=$ Certifico yo el doctor Don Diego de Zaconeta Ramires cura propio vicario y jues eclesiastico del beneficio de Cotpa que en distintos libros de partidas /foja71v/ de entierro de esta jurisdiccion se hallan las partidas que se iran sitando $=$ Antonio Condori en un libro forrado en pergamino blanco se hallo muerto a f 217 Joseph Choqueguanca en dicho libro se hallo muerto a f 217 Diego Guailla en dicho libro se hallo muerto a f 217 Pasqual Ticona en dicho libro se hallo muerto a f 217 Santos Mamani en dicho libro se hallo muerto a f 216 Joseph Alanoca en dicho libro se hallo muerto a f 218 buelta Juan Caseres en dicho libro se hallo muerto a f $230=$ Acencio Mamani en dicho libro se hallo muerto a f 237 Gabriel Paca en dicho libro se hallo muerto a f 240 Estevan Chino en dicho libro se hallo muerto a f 243 Juan Caseres en dicho libro se hallo muerto a f 246 Alberto Alabe en dicho libro se hallo muerto a f 260 Fransisco Molina en dicho libro se hallo muerto a f 274 Fausto Luque en dicho libro se hallo muerto a f 302 Juan Quibaillo en dicho libro se hallo muerto a f 323 buelta Guallatire $=$ certifico yo el doctor Don Diego de Zaconeta Ramires cura propio vicario y jues eclesiastico de Cotpa que en varios libros de partidas de entierros de esta jusrisdiciion se hallan las partidas que se iran sitando $=$ Clemente Carbajal en un libro forrado en badana colorada se hallo muerto a f $218=$

Diego Choque en dicho libro se hallo muerto a f 289 buelta

Hilario Guanca en dicho libro se hallo muerto a f 296

Choquelimpe $=$ Certifico yo el doctor don Diego Zaconeta Ramires cura propio vicario y jues eclesiastico del beneficio de Cotpa que en varios libros de partidas de entierros de esta jurisdiccion se hallan las partidas que se iran sitando $=$

Pasqual Zapana en un libro forrado en badana colorada se halló muerto a f 2 .

Rafael Zapana en dicho libro se hallo muerto a f $218=$

Bernardo Umiri en dicho libro se hallo muerto a f 286

Domingo Zapana en dicho libro se hallo muerto a f 226 /foja72r/

Parinacota $=$ Certifico yo el doctor don Diego Zaconeta Ramires cura propio vicario y jues eclesiastico del beneficio de Cotpa que en varios libros de partidas de entierros de esta jurisdiccion se hallan las partidas que se iran zitando $=$

Domingo Blanco en un libro forrado en badana colorada se hallo muer

to a $\mathrm{f} 226$

Juan Lopes en dicho libro se hallo muerto a f 233

Pablo Gomes en dicho libro se hallo muerto a f 254

Sebastian Flores en dicho libro se hallo muerto a f 293

Diego Guanca en dicho libro se hallo muerto a $\mathrm{f} 322$

Umagata $=$ Certifico yo el doctor don Diego Zaconeta Ramires cura propio vicario y jues eclesiastico del beneficio de Cotpa que en varios libros de partidas de entierros de esta jurisdiccion se hallan las partidas que se iran zitando $=$

Acencio Ramos Mamani en un libro forrado en badana colorada se hallo muerto a f 238.

Juan Vilca en dicho libro se hallo muerto a f 278.

Pasqual Quispe en dicho libro se hallo muerto a f 298

Fransisco Antonio en dicho libro se hallo muerto a f 324

Agustin Mamani en dicho libro se hallo muerto a f 313

$\underline{\text { Livilca }}=$ Certifico yo el doctor don Diego Zaconeta Ramires cura propio vicario y jues eclesiastico 
de este beneficio de Cotpa que en varios libros de partidas de entierros de esta jurisdiccion se hallan las partidas que se iran zitando $=$

Fransisco Mamani en un libro forrado en badana colorada se hallo muerto a f $218=$ Diego Ilario Caque en dicho libro se hallo muerto a f $228=$

Marcos Mamani en dicho libro se hallo muerto a f 230

Bartolome Medina en dicho libro se hallo muerto a f 239.

Joseph Albarado en dicho libro se hallo muerto a f 236 buelta

Joseph Flores Guanca en dicho libro se hallo muerto a f 236 buelta $=$

Diego Felipe Santos en dicho muerto a f 238

Pedro Cañipa en dicho libro se hallo muerto a f 272 buelta

Sebastian Mamani en dicho libro se hallo muerto a f 272 /foja72v/

Joseph Jauriondo en dicho libro se hallo muerto a f 272

Isidro Guanca en dicho libro se hallo muerto a f 324 buelta

Bernardo Quispe en dicho libro se hallo muerto a f 324 buelta

Diego Mamani en dicho libro se hallo muerto a f 326 buelta

Agustin Cañipa en dicho libro se hallo muerto a f 327

Concuerdan con su original a que me remito en el necesario y se debe adbertir que muchas partidas que no

s e enquentran en los libros, es por que mueren muchos en los Hospitales, otros en el valle de Lluta y otros en los

caminos y lugares donde ban con cargas - Cotpa y febrero quinse de mil

Petición setecientos setenta y quatro $=$ doctor Diego de Zaconeta Ramirez $=$ Señor Corregidor $=$ Don Diego Felipe Cañipa casique y governador propietario del repartimiento y doctrina de San Martin de Cotpa como mejor proceda de derecho paresco ante vuestra merced y digo que aviendoseme hecho saber la revicita y numeracion de indios que la justificasion de vuestra merced tiene tomada de dicho repartimiento por especial comicion del real y superior govierno de estos reinos para todos los repartimientos, que comprehende esta provincia hallo deberseme rebajar de los que son a mi cargo, por lo perteneciente a la presente numeracion y a la que actuo don Joachin Xavier de Cardenas, todos los indios que constan de la minuta de que hago presentacion con el juramento en derecho nesesario por averse ausentado de sus reducciones sin tener noticia de su paradero, cuya verdad protesto justificar con testigos, que por mi parte fuesen presentados, para lo qual ocurro a la integridad de vuestra merced para que mande se me reciba la dicha/foja73r/informacion y resultando de ella ser veridico lo que llebo expuesto se sirba su acreditada justificasion declararme por libre de los tributos que debian satisfacer los expresados indios rebajandoseme del padron, que me ha de entregar para la cobranza por tanto $=$ A vuestra merced pido y suplico se sirba mandar se me reciba dicha informacion y en lo demas mandar haser segun segun ba espuesto por ser de justicia

decreto jurando lo nesesario en derecho y para ello Don Diego Felipe Cañipa = Tacna y marso dose de mil setecientos setenta y quatro años = por presentada con la relacion de ausentes y muertos y recibasele la informacion que ofrece con zitacion del defensor de Real Hacienda: Asi lo proveo y firmo el señor Don Demetrio Egan del orden de Santiago theniente coronel de los reales ejercitos, corregidor y justicia mayor de la ciudad de Arica y su provincia por su magestad y jues de revicita en ella y por ante $\mathrm{mi}=$ Demetrio Egan $=$ Ante mi Juan Zanches Maldonado escrivano publico de cabildo minas y rexistros $=$ en dicho pueblo en dicho dia mes y año yo el escrivano zite ley e hise saber el auto que antecede al defensor de real hacienda Don Juan Estevan de Viscarra en su persona que lo oyo y entendio de que doi $\mathrm{fe}=$ Maldonado $=$ en

declaracion el pueblo de Tacna a dose dias del mes de marzo de mil setecientos setenta y quatro años para la informacion ofrecida y manda de recibir Don Diego Felipe Cañipa casique governador del pueblo de Cotpa presento ante su merced y por ante mi el escrivano por testigo a Prudencio Pe /foja73v/ rca vesino de dicho pueblo a quien le recibo juramento que lo hiso por dios nuestro señor y una señal de cruz bajo del cual prometo desir verdad en lo que supiere y fuere preguntado, y siendolo al tenor del escrito que esta por cabesa dijo $=$ A la primera pregunta dijo, que aora tres años conocio a Antonio Lupistaca en el pueblo de Pachama y que al presente no sabe donde para y responde $=$ Preguntado si conoce a Manuel Menacho, Clemente Atana y Joseph Ermenegildo dijo que no los conoce ni ha tenido noticia de estos tres y responde = Preguntado si conose a Pablo Caseres dise que se llama Pablo Peres y por ser sobrino de un cura Caseres le disen Pablo Caseres y responde $=$ Preguntado que tiempo hase que estubo el dicho Pablo en esta

provincia dijo que quando se hiso la numeracion de tributarios en la presente revicita lo bio el declarante que lo numeraron y asentaron por tributario y responde $=$ Preguntado este declarante si sabe del destino de dicho Pablo dijo que para en Carangas = Preguntado si sabe los motibos que tiene para estar ausente dicho Pablo dijo que por aver robado una casa se ausento = Preguntado dicho declarante que motibos tubo el dicho Antonio Lupistaca para ausentarse de la provincia dijo 
que por aver muerto a su muger a asotes $=$ Preguntado si conoce a conocio a Ignocencio Carrasco dijo que no lo conoce ni ha tenido noticia del y que lo que lleba dicho y declarado es la verdad bajo del juramento que fechado tiene en que se afirmo y ra /foja74r/ tifico, no lo firmo por no saber a su ruego lo hiso Ramon de Palsa con su merced por ante mi de que doi fe = Demetrio Egan a rruego del declarante Ramon de Palsa = Ante mi Juan Zanches Maldonado escrivano publico de

otra cavildo minas y rexistros $=$ en dicho pueblo dicho dia mes y año dichos para la dicha informacion presentó la parte por testigo ante su merced y por ante

mi el escrivano a Juan Sarabia vesino del pueblo de Cotpa a quien su merced le recibio juramento que lo hiso por Dios nuestro señor y una señal de cruz bajo del qual prometio desir verdad en lo que supiere y fuese preguntado y siendolo al tenor del escrito que esta por cabesa A la primera pregunta dijo que a Antonio Lupistaca lo conoce por noticia que tiene del y que a Manuel Menacho a Clemente Atana Joseph Ermenegildo y Pablo Caseres los conoce a todos por aver comunicado con ellos, pero que no sabe de que pueblos son a esepcion de Pablo Caseres, que dize el declarante es de su propio pueblo y que su propio nombre es Pablo Peres, y por ser sobrino de un cura llamado Caseres se tomo el apellido de Caseres y que unas veces se apellida Caseres y otras Perez Preguntado si sabe el paradero o destino de estos y que tiempo hase que los conocio y vio en esta provincia dijo que de ninguno puede asegurar el tiempo que ha que los bio por no acordarse y que solo del dicho Pablo Caseres o Peres tubo noticia que quando se hiso la numeracion de tributarios /foja74v/ en la presente revicita estubo en el pueblo de Cotpa y que lo numeraron por tributario al dicho Pablo y que para en Carangas por averlo desterrado el señor cura de aquella doctrina y que ignora el motibo = Preguntado si conoce a Inocencio Carrasco dijo que no lo conoce ni por noticia = Preguntado por los sujetos que contiene la presente lista dijo que a todos ellos los conoce a escepcion de Blas Mamani, Pedro Nolasco Alabe, Bartolome Quispe y Martin Tarque y que los que dise conocer se hallan ausentes muchos años de la provincia o doctrina de Cotpa y que no sabe el paradero de ellos, solo de Domingo Choque, que aora tres años lo vio en Azapa y que tambien sabe que Ipolito Alanoca y Alberto Samorano paran en la ciudad de Arequipa = Preguntado si sabe por que motibos se ausentaron dijo que no sabe ni ha tenido noticia del porque y que lo que lleba dicho y declarado es la verdad bajo del juramento que fechado tiene, que no le tocan las generales de la ley, que es de edad de treinta y sinco años, poco mas o menos no tubo que añadir ni quitar, no lo firmo por no saber a su ruego lo hiso Ramon de Palsa con su merced por ante mi de que doi fe $=$ Demetrio Egan $=$ A rruego del declarante Ramon de Palsa = Ante mi Juan Zanches

Maldonado escrivano publico de cavildo minas y rexistros = En dicho pueblo en dicho dia mes y año dichos para la dicha informacion el espresado casique y governador de la doctrina de Cotpa presento ante su merced y ante mi el escrivano por testigo a Mateo /foja75r/Crus Vecino del anexo de Umagata de la provincia de Cotpa a quien su merced le recibió juramento que lo hiso por Dios nuestro señor y una señal de crus bajo del qual prometio decir verdad en lo que supiere y fuere preguntado y siendolo al thenor del escrito que esta por cabesa = A la primera pregunta dijo que no conoce ni ha conocido a Antonio Lupistaca Clemente Atana y Pablo Caseres ni a Joseph Ermenegildo y que solo conoce a Manuel Menacho por que es de su propio pueblo = Preguntado si existe dicho Menacho en esta provincia dijo que no sabe ni el lugar donde se halla y que abra dos años que se ausentó de dicho pueblo = Preguntado si sabe los motibos por que se ausentó dijo que los ignora y responde $=$ Preguntado si conoce o conocio a Innocencio Carrasco dijo que lo conocio en su pueblo y que aora quatro años murio en su dicho pueblo de Umagata y responde que lo que lleba dicho y declarado es la verdad, bajo del juramento que lleba hecho en que se afirmo y ratifico leyda que le fue su declaracion se afirmó y ratificó que es de edad de treinta y un años, que no le tocan las generales de la ley, y no firmo por no saber a su ruego lo hiso Ramon de Palsa con su merced por ante mi de que doi fe Demetrio Egan = A rruego del declarante Ramon de Palsa = Ante mi Juan Zanches Maldonado escrivano publico de cavildo minas y rexistros = en

otra dicho pueblo dicho dia mes y año dichos para la dicha informacion el espresado governador presento ante su merced y ante mi el escribano por testigo a Bernardo Mollo vecino del pueblo de Cotpa / foja $75 v /$ a quien se le recibio juramento que lo hiso por Dios nuestro señor y una señal de crus bajo del qual prometio decir verdad en lo que supiere y fuere preguntado y siendolo al tenor del escrito que esta por cabesa = Preguntado si conoce a Antonio Lupistaca dijo que ahora años que asertibamente no se acuerda quantos habra tubo noticia de dicho Lupistaca y que nunca lo conocio de vista y que por aver hecho una aberia se ausentó de la provincia y que no sabe donde se halla = Preguntado si ha conocido a Manuel Menacho, Clemente Atana Joseph Ermenegildo y Pablo Caseres dijo que a esepcion del referido Pablo a ninguno de los otros conoce ni ha tenido

noticia de ellos y que el citado Pablo es natural del Pueblo de Cotpa = Preguntado que tiempo hase que el dicho Pablo falta de la doctrina de Cotpa

dijo que aunque ha tres años qua anda auzente en la presente revicita o numeracion de tributarios que se hiso en aquella doctrina se hallo presente el dicho Caseres y que el apellido de este es Pablo 
Perez y que por que es sobrino de un cura Caseres se apellida Caseres quando le tiene quenta $=$ preguntado donde para al presente el dicho Pablo dijo que en las provincia de Carangas por causa de aver hecho un robo en dicha doctrina y responde = Preguntado si conoce a Inocencio Carrasco dijo que no lo conoce ni ha tenido noticia del el en ningun tiempo y responde $=\mathrm{y}$ que lo que dicho $\mathrm{y}$ declarado lleba es la verdad bajo del juramento que fechado tiene /foja76r/

en que se afirmó y ratificó que es de edad de veinte y sinco años que no le tocan las generales de la ley; no lo firmo por no saber a su ruego lo hiso Ramon de Palsa con su merced por ante mi de que doi fe Demetrio Egan = A rruego del declarante Ramon de Palsa = Ante mi Juan Sanchez Maldonado escrivano publico de Cabildo minas y rexistros = en el mismo dia mes y año referidos para la dicha informacion ante su merced dicho señor corregidor y jues de esta causa presentó la parte por testigo a Fransisco Marca vesino del pueblo de Belen de la doctrina de Cotpa a quien su merced por ante mi el sitado escrivano le recibio juramento que lo hiso por Dios nuestro señor y una señal de crus bajo del qual prometio desir verdad en lo que supiere y fuere preguntado y siendolo al tenor del escrito que esta por cabesa dijo = Preguntado si conoce o ha tenido noticia de Antonio Lupistaca, Manuel Menacho, Clemente Atana, Joseph Ermenegildo y Pablo Caseres o Peres dijo que a ninguno de los dichos ha conocido ni por noticia y responde = preguntado si conoce a Innocencio Carrasco dijo lo mismo y responde y que lo que lleba dicho y declarado es la verdad bajo del juramento que fechado tiene en que se afirmó y ratificó que no le tocan las generales de la ley, que es de edad de quarenta y nuebe años y no lo firmo por no saber a su ruego lo hiso Ramon de Palsa con su merced por ante mi de que doi fe Demetrio Egan = A rruego del declarante Ramon de Palsa = Ante mi /foja76v/ Juan Zanches Maldonado escrivano publico de Cavildo minas y rexistros = Tacna y marso catorse de mil setecientos setenta y quatro = Vista la informacion antecedente corrasele traslado de ella al defensor de real hacienda para que segun lo que resultase se determine lo que combenga = proveyó y firmó el decreto de su uso el señor corregidor de esta provincia y jues revicitador por ante mi de que doi fee $=$ Demetrio Egan $=$ Ante mi Juan Zanches Maldonado escrivano publico de cavildo minas y rexistros $=$ señor jues de revicita $=$ el defensor de real hacienda vista la informacion que ha producido el casique Don Diego Felipe Cañipa, dise que absolutamente no ha probado la ausencia de Antonio Lupistaca, Manuel Menacho, Clemente Atana Pablo Caseres o Perez y la muerte de Innocencio Carrasco por lo que es de sentir que los susodichos queden por tributarios hasta que lo justifique plenamente, y que solo se le rebaje a Antonio Lupistaca por ser publico y notorio se huyo por aver muerto a su muger Tacna y marso quinse de mil setecientos setenta y

quatro = Juan Estevan Viscarra = Tacna y marso quinse de mil setecientos setenta y quatro conformandome con lo que espone el defensor de real hacienda, resuelbo que los sujetos nominados en la informacion antecedente, por no haver justificado el casique Don Diego Felipe Cañipa legalmente la ausencia de unos y la muerte del otro se declaren por tributarios, inter no pruebe plenamente lo que tiene por ofrecido, y solo se le rebaje a Antonio Lupista /foja77r/ ca, por tener en este mi jusgado una causa criminal que dio motibo a su fuga, y no averse podido averiguar su destino, lo que le hara saber el presente escrivano: proveyó y firmó lo de su uso decretado el señor

jues de revicita por ante mi Demetrio Egan = Ante mi Juan Zanches
Maldonado escrivano publico de cavildo minas y rejistros = rason que doi yo

don Diego Felipe Cañipa casique y governador del repartimiento de Cotpa de orden del señor general don Demetrio Egan theniente coronel de los reales exercitos corregidor y justicia maior de la provincia de Arica por su magestad de todos los bienes que poseo por mios propios y es en la manera siguiente $=$ Primeramente veinte mulas de carga aparejadas de reata abajo con sus odres $=$ Tambien sinco piesas de esclavos a saber dos negros dos negras y una mulatilla = tambien veinte y sinco marcos de plata labrada = tambien seis fanegadas de tierras zitas en la quebrada de Asapa pago nombrado Miraflores que compre de los herederos de Diego Cañipa = Las tierras de repartimiento que cultibo en la quebrada de Livilca = tambien dos fanegadas de tierras en el valle de Lluta y que compre a su magestad = segun ba expresado son los bienes que tengo poseo por mios propios en esta provincia y para que conste lo firmo en dies de marso de mil setecientos

Informe $\quad$ setenta y quatro = Diego Felipe Cañipa por el governador = Excelentisimo señor obedeciendo el orden de vuestra excelencia del articulo veinte y seis de la institucion de la revisita para informar a vuestra excelencia sobre la doctrina de Cotpa lo siguiente $=$ tiene casique governador que lo es Don Diego Felipe Cañipa con titu /foja77v/ los del superior govierno lo compone esta doctrina de dies y ocho pueblos cuia cavesa es el de Cotpa que tiene dos aillos nombrados Collana y Capanique el pueblo de Belen tiene otros dos que son Aransaia y Mancasaya. Los pueblos de Esquiña Pachica Timar Ticnamar Sacsamar, Guallatiri, Pachama, Socoroma, Livilca, Umagata, Sora, Putre, Parinacota, aciento de Choquelimpe y aillo de Caquena. Que se compone de estancias en la cordillera ay ha mas dos pueblos que son el de Poconchile y depende del pueblo de Belen y sus avitadores comprendidos en sus dos aillos de Aranzaya y Mancasaya y el pueblo de Churiña que se compone de tributarios del pueblo de Sora. Putre y Socoroma, a lo que ai tambien que añadir el pequeño valle de Chaca que es de esta doctrina que se compone de Hasiendas de viñas de españoles sin indio alguno. En todos 
los pueblos tienen los indios tierras y aguas suficientes y los tres topos menos en el de Cotpa que ai raro que los tenga y en Sacsamar que estan en tierras arrendadas segun expresa y me informo el casique. En el pueblo de Cotpa he hallado barios mestizos estos segun los livros de Iglecia parese establecieron sus padres y abuelos en el siglo pasado y por ser aquel tiempo poco los tributarios tomaron algunos topos de tierras en arriendo a los casiques de aquellos tiempos. Estos mestizos se han multiplicado el dia de oy pues pasan de cien familias de ellos las que viven en dicho pueblo Igualmente han ydo en aumento los indios y como las tierras son pocas se han hido repartiendo en los avitantes indios, y los mestizos poseeran has /foja78r/ ta unos veinte i cinco u treinta topos, y aunque el casique cobra en arriendo de ellos y me han echo representacion por parte de algunos indios no tienen las tierras correspondientes no he tomado deliberacion en hacer que dichas tierras de los mestisos se repartan a los indios respecto al tiempo que estos las poseen lo que tienen gastado en ellas, y el quitarselas en el dia era ocasionar una miseria en mas sien familias, todo lo que pongo en noticia de $\mathrm{Su}$ excelencia para que echo cargo de los motibos que expreso se libere si debo de amparar a los indios con dichas tierras o permitir continuen en ellas los mestisos los que estan promptos ha pagar a su magestad el valor de arriendo de ellas de solos los mestizos de Cotpa hai una compañia de milicias los que en tiempo de guerra hasen sin sueldo alguno el servicio de vigias en los puertos de Camarones ha distancia de veinte y sinco leguas al sur del puerto de Arica y otros que hay en la misma costa: Los pueblos de Parinacota Choquelimpe y Guallatire an ido a menos desde la ultima revicita por la decadencia de los minerales que antiguamente hauia a lo que tambien ha contribuido lo rrigido del temperamento. Paga todo tributario de esta doctrina a tres pessos un real por tercio, y lo mismo se cobra a los forasteros: mismos en el asiento de Choquelimpe que solo pagavan viente rreales y siendo solos nuebe tributarios he mandado al casique paguen lo mismo que los demas pues desfrutan los relabes de las antiguas minas. En esta doctrina no hai bienes de caja de comunidad, el casique ha manifestado por bienes propios suyos los siguientes como expresa la relacion firmada de su puño que esta a fojas de todos los autos de revicita, y con lo que asegura los reales tributos $=$ razon que doy yo don Diego Phelipe Cañipa casique governador del repartimiento de Codpa de orden del señor general Don Demetrio Egan Theniente coronel de los reales exercitos corregidor y justicia mayor de la ciudad de Arica y su provincia por su magestad todos los bienes que poseo mios propios y es en la manera siguiente $=$ Primeramente de /foja78v/ veinte mulas de carga aparejadas de reata para abajo con sus odres $\mathrm{Y}$ tambien sinco piesas de esclavos a saver dos negros dos negras y una mulatilla $=\mathrm{y}$ tambien veinte $\mathrm{y}$ sinco marcos de plata labrada $=$ tambien seis fanegadas de tierras sitas en la quebrada de Asapa pago nombrado Miraflores que compre de los herederos de Diego Cañipa $=$ Las tierras de repartimiento que cultivo en la quebrada de Livilca $=\mathrm{Y}$ tambien dos fanegadas de tierras en el valle de Lluta y que compre a su magestad Segun ba expresado: son los bienes que tengo y poseo por mios propios en esta provincia y para que conste lo firme en dies de Marzo de mil setecientos setenta y quatro años = Diego Phelipe Cañipa = se rebajan en esta doctrina para sacristanes cantores, alcaldes, principales veinte y tres yndios en la forma siguiente un segunda, seis sacristanes, seis cobradores y diez para los alcaldes de los pueblos Se han revicitado setecientos setenta y nuebe tributarios resultando de aumento de la revicita passada ochenta y quatro indios tributarios. La revicita se actuo ante mi y testigos porque el esscribano de esta provincia se resivio estando finalisando la numeracion y solo las diligencias posteriores de ella las autorisó como se demuestra y juro a Dios y a la cruz de mis pechos haverla practicado como fiel vasallo de su magestad sin agraviar a perzona alguna en comun ni en particular y solo arreglado a las instrucciones que se me remitieron por ese superior govierno y llebar el fin unico a que su magestad no fuese defraudado en su patrimonio porque se tiene por experiensia que los indios se ausentan de sus origenes con solo el dicho fin. Nuestro señor guarde a Su excelencia muchos años Tacna y marzo dies y ocho de mil setecientos setenta y quatro $=$ Exselentissimo Señor Demetrio Egan = Ante mi Juan Zanches Maldonado Escrivano Publico de cavildo minas y rexistros = Entre renglones que no [manuscrito ilegible] Diego = casado con Maria Quenaya de veinte años /foja79r/ Lasaro $=$ de trese años $=$ saxsa $=$ Y mita $=$ manera $=$ el defensor de real hazienda $=$ demas ministros de ella $=$ el pueblo de Libilca tiene sus tieras $=$ todo vale $=$ Enmendada $=$ el $=$ par $=$ Fransisco $=$ Manuela Feliciana $=$ Totoñ $=$ todo vale $=$ testado $=$ mestiso nobale $=$ ochota $=$ dies $y$ seis $=$ nobale $=$ miento $=$ año $=$ anos $=$ suso $=$ todo vale $=$

Concuerda con los autos originales de revicita que se remitieron al real y superior govierno de estos reinos para su aprobacion esta fiel y legalmente sacado corregido y concertado aqui me refiero y de mandato del señor Don Demetrio Egan del orden de Santiago theniente coronel de los reales ejercitos corregidor y justicia maior de la ciudad de Arica y su provincia por su magestad y jues revicitador en ella por especial comicion de dicho real y superior govierno doi el presente en dies y ocho dias del mes de marso de mil setecientos setenta y quatro años.

\footnotetext{
1 "Ochenta y tres" originalmente, "setenta y ocho" sobrepuesto
} 


\section{Indice Toponímico de \\ La Revisita de Codpa (altos de Arica) de 1772- 1773 del corregidor \\ Demetrio Egan}

Arequipa

Arica (ciudad/provincia)

Ayaviri

Azapa (quebrada)

Belen (pueblo)

Calocoto,

Camarones (puerto)

Camiña

Carangas

Codpa (Doctrina)

Cosapa

Chaca (valle)

Choquelimpe (asiento)

Chuquisaca

Churiña

Desaguadero,

Esquiña (pueblo)

La Paz,

Libilca (pueblo)

Lluta (valle)

Miñimiñi

Miraflores (pago)

Ocaguataya (pago)

Omasuyos (provincia)

Oruro

Pachama

Pachica (pueblo) Portada

Parinacota (pueblo)

Poconchile (pago)

Putre (pueblo)

Sacsamar (pueblo)

Sibaya

Socoroma (pueblo de los Altos de Arica)

Sora (pueblo)

Tacna (ciudad)

Tarapacá

Tignamar (pueblo)

Timar (pueblo)

Totora (provincia de Carangas)

Turco

Umagata

Vilavila (pago) fs. $17 \mathrm{v}, 74 \mathrm{v}$

fs. $1 \mathrm{r}-\mathrm{v}, 2 \mathrm{r}, 6 \mathrm{v}, 7 \mathrm{r}, 8 \mathrm{v}, 9 \mathrm{r}-\mathrm{v}, 10 \mathrm{r}-\mathrm{v}, 11 \mathrm{r}-\mathrm{v}, 12 \mathrm{r}, 13 \mathrm{r}, 48 \mathrm{r}, 63 \mathrm{v}, 64 \mathrm{r}-\mathrm{v}$, $65 \mathrm{r}-\mathrm{v}, 66 \mathrm{r}-\mathrm{v}, 67 \mathrm{v}, 73 \mathrm{r}, 77 \mathrm{r}, 78 \mathrm{r}, 79 \mathrm{r}$

fs. $30 \mathrm{r}, 33 \mathrm{v}$

fs. $66 \mathrm{v}, 74 \mathrm{v}, 77 \mathrm{r}, 78 \mathrm{v}$.

fs. $41 \mathrm{r}, 45 \mathrm{r}, 66 \mathrm{r}, 70 \mathrm{r}, 76 \mathrm{r}, 77 \mathrm{v}$

fs. $39 \mathrm{v}, 50 \mathrm{v}, 51 \mathrm{v}, 53 \mathrm{r}$

f. $78 \mathrm{r}$

fs. $24 \mathrm{v}, 25 \mathrm{r}$

fs. $14 \mathrm{r}, 17 \mathrm{v}, 18 \mathrm{r}, 20 \mathrm{v}, 21 \mathrm{r}-\mathrm{v}, 24 \mathrm{r}-\mathrm{v}, 25 \mathrm{r}-\mathrm{v}, 26 \mathrm{r}, 30 \mathrm{r}, 32 \mathrm{r}, 33 \mathrm{r}-\mathrm{v}, 35 \mathrm{v}$, $36 \mathrm{r}, 37 \mathrm{v}, 39 \mathrm{v}, 43 \mathrm{r}, 47 \mathrm{r}, 51 \mathrm{r}, 61 \mathrm{v}, 62 \mathrm{v}, 73 \mathrm{v}, 74 \mathrm{v}, 75 \mathrm{v}$.

fs. $11 \mathrm{r}-\mathrm{v}, 12 \mathrm{r}-\mathrm{v}, 13 \mathrm{r}, 16 \mathrm{r}, 63 \mathrm{v}, 64 \mathrm{r}-\mathrm{v}, 65 \mathrm{r}-\mathrm{v}, 66 \mathrm{r}-\mathrm{v}, 67 \mathrm{r}-\mathrm{v}, 68 \mathrm{r}-\mathrm{v}, 69 \mathrm{r}-\mathrm{v}$, 70r-v, 71r-v, 72r-v, 73r, 74r-v, 75r-v, 76r, 77r-v, 78r.

fs. $36 \mathrm{r}, 39 \mathrm{v}, 47 \mathrm{r}, 50 \mathrm{v}, 51 \mathrm{r}$

f. $77 \mathrm{v}$

fs. $61 \mathrm{r}, 71 \mathrm{v}, 77 \mathrm{v}, 78 \mathrm{r}$.

f. $19 \mathrm{v}$

f. $77 \mathrm{v}$

fs. $43 \mathrm{r}$

fs. $22 \mathrm{v}, 66 \mathrm{r}, 69 \mathrm{r}, 77 \mathrm{v}$.

fs. $14 \mathrm{r}, 35 \mathrm{v}, 43 \mathrm{r}$

fs. $38 \mathrm{v}, 66 \mathrm{v}, 72 \mathrm{r}, 77 \mathrm{r}-\mathrm{v}, 78 \mathrm{v}, 79 \mathrm{r}$

fs. $72 \mathrm{v}, 77 \mathrm{r}, 78 \mathrm{v}$

f. $17 \mathrm{v}, 24 \mathrm{v}$

fs. $77 \mathrm{r}, 78 \mathrm{v}$

f. $66 \mathrm{r}$

f. $51 \mathrm{r}$

f. $27 \mathrm{v}$

fs. $34 \mathrm{r}, 63 \mathrm{v}, 66 \mathrm{r}, 70 \mathrm{r}, 73 \mathrm{v}, 77 \mathrm{v}$.

fs. $19 \mathrm{v}, 66 \mathrm{r}, 69 \mathrm{v}, 77 \mathrm{v}$.

fs. $59 \mathrm{r}, 66 \mathrm{v}, 72 \mathrm{r}, 77 \mathrm{v}, 78 \mathrm{r}$.

fs. $66 \mathrm{r}, 77 \mathrm{v}$.

fs. $54 \mathrm{v}, 66 \mathrm{r}, 71 \mathrm{r}, 77 \mathrm{v}$

fs. $32 \mathrm{v}, 66 \mathrm{r}, 77 \mathrm{v}$.

f. $25 \mathrm{r}$

fs. $48 \mathrm{r}, 66 \mathrm{r}, 70 \mathrm{v}, 77 \mathrm{v}$

fs. $53 \mathrm{r}, 66 \mathrm{r}, 66 \mathrm{v}, 71 \mathrm{r}, 77 \mathrm{v}$

fs. $7 \mathrm{r}-\mathrm{v}, 8 \mathrm{r}-\mathrm{v}, 9 \mathrm{r}-\mathrm{v}, 10 \mathrm{r}-\mathrm{v}, 35 \mathrm{v}, 66 \mathrm{v}, 73 \mathrm{r}, 76 \mathrm{v}, 78 \mathrm{v}$.

fs. $21 \mathrm{v}$

fs. $29 \mathrm{r}, 66 \mathrm{r}, 69 \mathrm{v}, 77 \mathrm{v}$.

fs. $26 \mathrm{v}, 66 \mathrm{r}, 69 \mathrm{v}, 70 \mathrm{r}, 77 \mathrm{v}$.

f. $35 \mathrm{v}$

f. $25 \mathrm{y}$

fs. $36 \mathrm{v}, 66 \mathrm{v}, 72 \mathrm{r}, 75 \mathrm{r}, 77 \mathrm{v}$

f. $66 \mathrm{v}$ 


\section{Indíce Onomástico de \\ La Revisita de Codpa (altos de Arica) de 1772- 1773 del corregidor Demetrio Egan}

Alabe, Thomas (principal del pueblo de Esquiña)

Amat y Junient, Manuel (virrey del Perú)

Aransaia (ayllu del pueblo de Belén)

Aransaya

Apas, Thomas (mozo)

Arco, Pedro de (testigo)

Atana, Clemente (fugitivo)

Bamondes, Rafael (testigo y amanuense)

Blanco, Andrés (español casado con María Cañipa)

Blas, Matheo (principal ayllu Capanique en Codpa)

Buitron, Juan (principal)

Cáceres, Pablo

Calderón de la Barca, Fausto (Oficial Real)

Cañipa, Diego Felipe (Cacique y gobernador de Codpa)

Capanique (ayllu)

Cárdenas, Joachin Xavier de (Revisitador a 1750)

Carrasco, Ignocencio (fugitivo),

Castro, Joseph Joaquin de (Oficial Real)

Collana (ayllu)

Contreras, Casildo (vecino de Poconchile)

Coquena, (ayllu)

Choque, Vizente (impedido)

Choqueguanca, Pablo (ciego)

Egan, Demetrio (Corregidor de Arica, Juez revisitador)

Ermenegildo, Joseph (fugitivo)

García, Martín (oficial real)

Gonzales Vigil, Joaquín (testigo)

Guallatiri

Guallatire (ayllu)

Lavaien, Gregorio

Lavayen, Gregorio (testigo)

Leuro, Joseph de (contaduría)

Lopes de Santana, Juan

López de Santana, Juan Jossef (Protector de Indios)

Lupistaca, Antonio (fugitivo)

Machaca, Nicolas (tullido)

Mancasaya, (ayllu del pueblo de Belén)

Maquera, Acencio (principal)

Menacho, Manuel (fugitivo)

Murgnia, Miguel de (testigo)

Navarro, Juan Francisco (contaduría)

Nina, Santiago (tullido)

Paca, Francisco (cojo)

Peres, Pablo (fugitivo)

Peres, Vicente (mudo)

Ramos, Diego (ciego)

Ramos, Ilario (principal)

Saconeta, Diego de f. $22 \mathrm{v}$

fs. $1 \mathrm{r}, 7 \mathrm{r}$

fs. $77 \mathrm{v}$

fs. $45 \mathrm{r}$ Vease Aransaia

f. $42 \mathrm{v}$

f. $68 \mathrm{r}$

fs. $63 \mathrm{v}, 73 \mathrm{v}, 74 \mathrm{r}, 75 \mathrm{r}-\mathrm{v}, 76 \mathrm{r}-\mathrm{v}$

fs. $7 \mathrm{v}, 8 \mathrm{r}, 9 \mathrm{r}-\mathrm{v}, 10 \mathrm{r}, 64 \mathrm{r}$

f. $13 \mathrm{r}$

f. $16 \mathrm{r}$

f. $13 \mathrm{r}$

fs. 73v, 74r, 75r-v, 76r-v Ver Peres, Pablo

fs. $8 \mathrm{r}$

fs. $13 \mathrm{r}, 63 \mathrm{v}, 64 \mathrm{r}-\mathrm{v}, 65 \mathrm{r}-\mathrm{v}, 66 \mathrm{r}-\mathrm{v}, 67 \mathrm{r}, 68 \mathrm{r}, 72 \mathrm{v}, 73 \mathrm{r}$, $76 \mathrm{v}, 77 \mathrm{r}, 78 \mathrm{r}-\mathrm{v}$.

fs. $16 \mathrm{r}, 77 \mathrm{v}$

f. $13 \mathrm{r}, 72 \mathrm{v}$

fs. $73 \mathrm{v}, 74 \mathrm{v}, 75 \mathrm{r}-\mathrm{v}, 76 \mathrm{v}$

fs. $8 \mathrm{r}$

fs. $13 \mathrm{r}, 77 \mathrm{v}$

fs. $66 \mathrm{r}$

fs. $62 \mathrm{r}, 64 \mathrm{v}, 65 \mathrm{r}-\mathrm{v}, 66 \mathrm{v}, 67 \mathrm{v}, 77 \mathrm{v}$

f. $26 \mathrm{r}$

f. $60 \mathrm{v}$

fs. $1 \mathrm{r}, 2 \mathrm{r}, 7 \mathrm{r}-\mathrm{v}, 8 \mathrm{v}, 9 \mathrm{r}-\mathrm{v}, 10 \mathrm{r}-\mathrm{v}, 11 \mathrm{r}-\mathrm{v}, 12 \mathrm{r}-\mathrm{v}, 13 \mathrm{r}, 63 \mathrm{v}$, 64r-v, 65v, 66v, 67r-v, 68r, 73r, 74r-v, 75r, 76r-v, $77 \mathrm{r}, 78 \mathrm{r}, 78 \mathrm{v}, 79 \mathrm{r}$.

fs. $63 \mathrm{v}, 73 \mathrm{v}, 74 \mathrm{r}, 75 \mathrm{r}-\mathrm{v}, 76 \mathrm{r}$

f. $68 \mathrm{r}$

fs. $10 \mathrm{v}, 11 \mathrm{v}, 12 \mathrm{r}-\mathrm{v}$

fs. $63 \mathrm{v}, 77 \mathrm{v}$ Vease Guallatire

fs. $66 \mathrm{v}, 71 \mathrm{v}, 78 \mathrm{r}$

fs. $64 \mathrm{r}, 67 \mathrm{v}$ Ver Lavayen, Gregorio

fs. $10 \mathrm{r}, 64 \mathrm{v}, 65 \mathrm{v}, 67 \mathrm{r}$

fs. $2 \mathrm{r}, 6 \mathrm{v}, 7 \mathrm{r}$

fs. 64r-v, 65r Vease Lopez de Santana, Juan

fs. $7 \mathrm{v}, 8 \mathrm{v}, 9 \mathrm{r}, 63 \mathrm{v}$

fs. $63 \mathrm{v}, 73 \mathrm{v}, 74 \mathrm{r}, 75 \mathrm{v}, 76 \mathrm{r}-\mathrm{v}$.

f. $26 \mathrm{r}$

fs. $41 \mathrm{r}, 77 \mathrm{v}$.

f. $41 \mathrm{r}$

fs. $73 \mathrm{v}, 74 \mathrm{r}, 75 \mathrm{r}-\mathrm{v}, 76 \mathrm{r}-\mathrm{v}$

fs. $64 \mathrm{v}, 65 \mathrm{v}$.

fs. $7 \mathrm{r}$.

f. $47 \mathrm{r}$

f. $57 \mathrm{v}$

fs. $73 \mathrm{v}, 74 \mathrm{r}, 76 \mathrm{r}-\mathrm{v}$

f. $38 \mathrm{r}$

f. $26 \mathrm{v}$

f. $45 \mathrm{r}$

f. $13 \mathrm{r}, 65 \mathrm{v}, 67 \mathrm{v}, 68 \mathrm{v}, 69 \mathrm{r}, 70 \mathrm{r}$ Ver Zaconeta Ramires, Diego 
Sansola, Esteban (principal del pueblo de Pachica)

Toledo (Virrey)

Velasco y Vrdanibia, Juan de (testigo/Comisionado)

Vilanoba, Bernardo (alguacil mayor de revisita)

Viscarra, Juan Esteban de (defensor de la Real Hacienda)

Ximenes, Joseph Sinforiano (intérprete)

Zaconeta y Ramírez, Diego (cura y vicario propietario de Codpa)

Zanches Maldonado, Juan (escribano público de Cabildo, Minas y registros) f. $19 \mathrm{v}$

f. $3 \mathrm{r}$

fs. $7 \mathrm{v}, 8 \mathrm{r}-\mathrm{v}, 9 \mathrm{r}-\mathrm{v}, 10 \mathrm{r}-\mathrm{v}, 11 \mathrm{v}, 12 \mathrm{v}, 64 \mathrm{r}-\mathrm{v}, 65 \mathrm{v}, 67 \mathrm{r}, 67 \mathrm{v}$

fs. $9 \mathrm{r}-\mathrm{v}, 11 \mathrm{v}, 12 \mathrm{r}, 64 \mathrm{r}-\mathrm{v}, 65 \mathrm{r}-\mathrm{v}, 66 \mathrm{r}, 67 \mathrm{r}-\mathrm{v}$

fs. $8 \mathrm{r}-\mathrm{v}, 13 \mathrm{r}, 64 \mathrm{r}, 73 \mathrm{r}, 76 \mathrm{v}$.

fs. $10 \mathrm{v}, 64 \mathrm{r}$

f. $11 \mathrm{r}, 11 \mathrm{v}, 63 \mathrm{v}, 64 \mathrm{r}, 66 \mathrm{v}, 67 \mathrm{v}, 68 \mathrm{r}-\mathrm{v}, 69 \mathrm{v}, 70 \mathrm{r}-\mathrm{v}, 71 \mathrm{r}-\mathrm{v}$, $72 \mathrm{r}-\mathrm{v}$.

fs. $73 \mathrm{r}, 74 \mathrm{r}, 75 \mathrm{r}, 76 \mathrm{r}-\mathrm{v}, 77 \mathrm{r}, 78 \mathrm{v}$. 